\title{
Medical technology assessment in surgery : costs and effects of dynamic graciloplasty and combined pancreas kidney transplantation
}

Citation for published version (APA):

Adang, E. M. M. (1997). Medical technology assessment in surgery : costs and effects of dynamic graciloplasty and combined pancreas kidney transplantation. [Doctoral Thesis, Maastricht University]. Maastricht University. https://doi.org/10.26481/dis.19971121ea

Document status and date:

Published: 01/01/1997

DOI:

10.26481/dis.19971121ea

Document Version:

Publisher's PDF, also known as Version of record

Please check the document version of this publication:

- A submitted manuscript is the version of the article upon submission and before peer-review. There can be important differences between the submitted version and the official published version of record.

People interested in the research are advised to contact the author for the final version of the publication, or visit the DOI to the publisher's website.

- The final author version and the galley proof are versions of the publication after peer review.

- The final published version features the final layout of the paper including the volume, issue and page numbers.

Link to publication

\footnotetext{
General rights rights.

- You may freely distribute the URL identifying the publication in the public portal. please follow below link for the End User Agreement:

www.umlib.nl/taverne-license

Take down policy

If you believe that this document breaches copyright please contact us at:

repository@maastrichtuniversity.nl

providing details and we will investigate your claim.
}

Copyright and moral rights for the publications made accessible in the public portal are retained by the authors and/or other copyright owners and it is a condition of accessing publications that users recognise and abide by the legal requirements associated with these

- Users may download and print one copy of any publication from the public portal for the purpose of private study or research.

- You may not further distribute the material or use it for any profit-making activity or commercial gain

If the publication is distributed under the terms of Article 25fa of the Dutch Copyright Act, indicated by the "Taverne" license above, 


\section{MEDICAL TECHNOLOGY ASSESSMENT IN SURGERY}




\section{MEDICAL TECHNOLOGY ASSESSMENT IN SURGERY}

\section{Costs and Effects of Dynamic Graciloplasty and Combined Pancreas Kidney Transplantation}

\section{PROEFSCHRIFT}

ter verkrijging van de graad van doctor

aan de Universiteit Maastricht, op gezag van de Rector Magnificus Prof. Mr. M.J. Cohen, volgens het besluit van het College van Decanen, in het openbaar te verdedigen op vrijdag 21 november 1997 om 12.00 uur door

\section{Edwin Matbias Marie Adang} geboren te Roermond op 9 mei 1964 
Promotor:

Prof. dr. G. Kootstra

Co-promotores:

Dr. C.G.M.I. Baeten

Dr. G.L. Engel (Coordinator VAZ, Utrecht)

Beoordelingscommissie:

Prof.dr. J.M.J.P. van der Linden (Voorzitter)

Prof.dr. J.A. Janknegt

Prof.dr. J.A.M. Maarse

Prof.dr. F.F.H. Rutten (Erasmus Universiteit Rotterdam)

Prof.dr. H. Troidl (Universität zu Köln, Deutschland)

These studies were financially supported by the Health Insurance Executive Board (Ziekenfondsraad, commissie ontwikkelingsgeneeskunde). 


\section{MUURBLOEM}

Er zijn vele wegen, Maar de juiste weg Is de weg er tegen;

Niet de wey er onder, Dat is anderkruiperij; Niet de weg er over Dat is pluimstrijkerij Maar de weg er tegen, Tegen alle wegen in En dat is van de wijsbeid Nog maar bet begin

(Bertus Aafjes, Het Gevecht met de Muze (1940)) 
Aan mijn vrouw en mijn kinderen. 


\section{Contents}

General Introduction $\ldots \ldots \ldots \ldots \ldots \ldots \ldots \ldots \ldots \ldots \ldots \ldots \ldots \ldots \ldots \ldots$

1 Medical Technology Assessment and the role of Economic Evaluation in Health

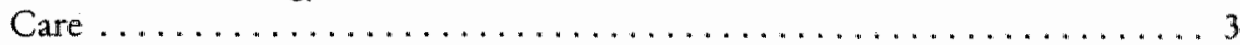

2 Surgeon and Economist together in a Study: A win-win Situation $1 . . . \ldots 19$

3 Quality of life after dynamic graciloplasty for fecal incontinence ....... 31

4 Cost-effectiveness of dynamic graciloplasty in patients with fecal incontinence

5 Comparison prior to and after transplantation of pancreas-kidney and pancreaskidney with loss of pancreas, a prospective controlled Quality of Life study . 65

6 In chronically ill patients, retrospective, post-treatment quality of life reports

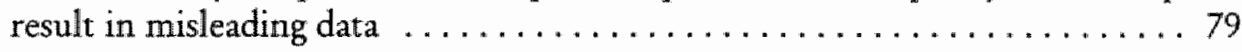

T Discussion, Conclusions, and Recommendations ............. 91

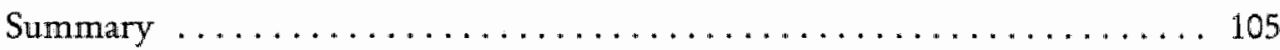

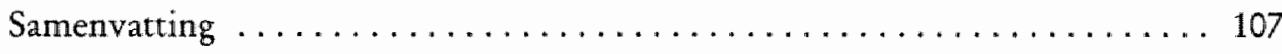

Dankwoord ........................................ 109

List of Publications $\ldots \ldots \ldots \ldots \ldots \ldots \ldots \ldots \ldots \ldots \ldots \ldots \ldots \ldots$

Curriculum Vitae $\ldots \ldots \ldots \ldots \ldots \ldots \ldots \ldots \ldots \ldots \ldots \ldots \ldots \ldots \ldots \ldots$ 


\section{General Introduction}

\section{Introduction}

Since the end of World War II expenditure on health-care has been growing. Healthcare costs have risen in both relative and absolute terms. The most important reasons for these growing expenditures are: rising prices, aging of the population, increasing demands on quality of care and a continuous growth in technological possibilities. Since the last two decades, health-care policy makers have become strongly interested in controlling these expenditures, because public sector resources were recognised to be limited. One of the consequences of a policy based on controlling health care expenditures is that choices among medical technologies have to be made. The money the government spends on one particular technology cannot be used for a different kind of technology in the field of health care. ${ }^{\prime}$

Technology in this context is not restricted to apparatus. The Office of Technology Assessment (OTA, 1978) defined 'Technology" as: "the drugs, devices, medical and surgical procedures used in medical care, and the organisation and support systems within which such care is provided".

Medical Technology Assessment (MTA) can be a valuable tool to assist policymakers at different levels, for example, government and hospitals, with regard to which, how much and where technologies should be provided. MTA evaluates the different aspects of a technology in order to provide the Government and her advisors, health insurance companies, hospital boards, clinicians, and general practitioners (GPs) with comprehensive information. However, the aims of MTA go further: its results are instrumental in finding the correct indications for new treatments and, occasionally, to adjust protocols. ${ }^{3}$

The aim of this thesis is to present two experimental studies, Dynamic Graciloplasty (DGP) and Combined Pancreas Kidney Transplantation (PKT) performed in the Netherlands. Both studies incorporate aspects of MTA. Furthermore, the fact whether prospective quality of life judgements differ from retrospective quality of life judgements is an important issue in the thesis. The final aim of this thesis is to formulate recommendations for further improvement with regard to the quality of Medical Technology Assessments.

The outline of the thesis is as follows. Chapter 1 describes the concept of MTA and the role of economic evaluation in health care. Furthermore it explains the 
techniques for economic evaluation: cost-benefit, cost-effectiveness, and cost-utility analysis. Finally an evalluation of the techniques, based on welfare economic theory and a discussion on whether these techniques are applicable in practice, is presented. Chapter 2 addresses one of the characteristic features of MTA, the multidisciplinairy approach. This chapter identifies the multidisciplinairy cooperation, necessary for MTA, as a win-win situation. Chapter 3 reports on an empirical study in which quality of life of patients who underwent DGP in the treatment of intractable fecal incontinence was investigated. Chapter 4 reports on an empirical study into the costs of the procedure DGP compared to the alternative treatments, for the Dutch health care setting. The cost analysis was done from a societal perspective. Furthermore, quality of life data were extended and combined with the cost data, resulting in a cost-effectiveness analysis. Chapter 5 reports on an empirical multicenter study, specifically the part concerning prospective quality of life of insulin dependent patients with end stage renal disease who underwent a PKT. Chapter 6 reports on an empirical study which deals with the phenomenon that prospective quality of life judgements differ from retrospective quality of life judgements. This study provides valuable information about the difference between quality of life ratings pertaining to the current time and those pertaining to a previous time. Finally, chapter 7 presents a discussion and conclusions, and furthermore, gives recommendations with regard to the design of future M'TA's.

\section{References}

1 Adang EMM, Dirksen CD, Engel GL, Baeten CGMI. (1995) Medical technology assessment: economic evaluation of new technologies. British Journal of Hospital Medicine 53;11:563-566.

2 Office of Technology Assessment (1978) Assessing the efficacy and safety of medical rechnologies. Government Printing Office, Washington, DC, USA.

3 Engel GL, Adang EMM, Kootstra G. (1994) Surgeon and economist together in a study: a winwin situation! In Okonomie und ChḦurgie: Konsens oder Dissens? Effektivität und Ökonomie Chirurgischen Handelns, E. Neugebauer und H. Troidl, Georg Thieme Verlag Stuttgart-New York pp.16-21. 


\section{Medical Technology Assessment and the role of Economic Evaluation in Health Care}

This chapter was originally published under the title:

Medical technology assessment and the role of economic evaluation in health care. Adang EMM, Ament A, Dirksen CD. Journal of Evaluation in Clinical Practice $1996 ; 2 ; 4: 287-294$. 


\section{Summary}

The growth in health care expenditure over the last few decades has necessitated the introduction of priority setting and decision making based on the results of critical evaluation. Medical Technology Assessment (MTA) is a valuable tool to assist policymakers in controlling new medical and existing technologies. Medical Technology Assessment, and the role of economic evaluation as part of MTA are described, and various techniques of economic evaluation are discussed.

\section{Introduction}

Expenditure on health-care in the last fifty years has been growing. Health-care costs have risen in both relative and absolute terms. Table 1 presents data from selected countries, which show the relative costs as a percentage of Gross Domestic Product (GDP). There is no consensus on the term 'health care expenditures'. Germany, for example, in contrast to the Netherlands, does not include institutes for mentally handicapped and day-care for the handicapped in calculations of health care expenditure. Similar differences can be noticed when comparing the Netherlands to, for instance, Denmark, France and Switzerland. 
Table 1 Health Care expenditures as a percentage of GDP in 1975 and 1989

\begin{tabular}{lll}
\hline Country & 1975 & 1989 \\
\hline Sweden & $8,0 \%$ & $8,8 \%$ \\
France & $6,8 \%$ & $8,7 \%$ \\
Iceland & $5,9 \%$ & $8,6 \%$ \\
The Netherlands & $7,7 \%$ & $8,3 \%$ \\
Austria & $7,3 \%$ & $8,2 \%$ \\
Germany & $7,8 \%$ & $8,2 \%$ \\
Switzerland & $7,0 \%$ & $7,8 \%$ \\
Italy & $5,8 \%$ & $7,6 \%$ \\
Norway & $6,7 \%$ & $7,6 \%$ \\
Luxembourg & $5,7 \%$ & $7,4 \%$ \\
Ireland & $7,7 \%$ & $7,3 \%$ \\
Belgium & $5,8 \%$ & $7,2 \%$ \\
Finland & $6,3 \%$ & $7,1 \%$ \\
Denmark & $6,5 \%$ & $6,3 \%$ \\
Spain & $5,1 \%$ & $6,3 \%$ \\
Portugal & $6,4 \%$ & $6,3 \%$ \\
United Kingdom & $5,5 \%$ & $5,8 \%$ \\
Greece & $4,1 \%$ & $5,1 \%$ \\
\hline OECD average & $6,5 \%$ & $7,4 \%$ \\
\hline
\end{tabular}

Source: Schieber et al. (1991). OECD Health Data, 1991. OECD = Orgamisation for Economic Cooperation and Development

Table 2 shows the differences in expenditures between the Netherlands and other countries, with 'matched' benefit packages. It shows that, except for France, the differences between countries are smaller than table 2 suggests.

Table 2 Health care expenditures as percentage of gross domestic product 1992-1993

\begin{tabular}{|c|c|c|c|c|c|c|}
\hline & \multirow[b]{2}{*}{ Year } & \multicolumn{2}{|c|}{$\begin{array}{c}\text { National statistical } \\
\text { Bureaus }\end{array}$} & \multicolumn{3}{|c|}{$\begin{array}{c}\mathrm{CBS}^{*} \text { calculations on comparable } \\
\text { benefit packages }\end{array}$} \\
\hline & & $\%$ GDP & difference & $\% G D P$ & Netherlands & difference \\
\hline \multirow[t]{2}{*}{ Netherlands } & 1992 & 8.5 & & & & \\
\hline & 1993 & 8.7 & & & & \\
\hline Denmark & & 6.7 & -2.0 & 6.1 & 6.4 & -0.3 \\
\hline Germany & 1992 & 14.0 & 5.5 & 10.1 & 8.0 & 2.1 \\
\hline France & 1993 & 9.8 & 1.1 & 9.3 & 7.2 & 2.1 \\
\hline Switzerland & 1992 & 9.3 & 0.8 & 9.3 & 9.3 & 0.0 \\
\hline
\end{tabular}


Western European countries are currently struggling with tremendous budgetary problems. Since 1970, government spending in Western Europe has risen from $36.5 \%$ of the GDP to almost $51 \%{ }^{1}$ According to a 1993 survey by Andersen Consulting, medical costs in 10 Western European countries rose by an average of $4.1 \%$ in real terms each year between 1970 and 1990 , while real economic growth during the same period increased by only $2.7 \%$ annually. ${ }^{2}$ The rise in health care spending is particularly worrying, because it is mostly caused by factors beyond governmental control. The most important reasons for these growing expenditures are: rising prices, aging of the population, increasing demands on quality of care and a continuous growth in technological possibilities.

The method most commonly used in government-funded health care systems to limit costs is to ration or completely block access to new and costly medical technology. Pharmaceuticals in particular are often targeted. The Dutch parliament, for example, has asked the government to evaluate the medicines on the Dutch market on the basis of four criteria: necessity, efficacy, efficiency and whether the costs of a certain pharmacotherapy can be carried by the patient.

Over the last two decades, health care policymakers have become increasingly interested in controlling the expenditure precipitated by the constant development and availability of new medical technologies. Employing all of these new technologies would cause growing pressure on public sector resources, and, choices among medical technologies should therefore be made.

Health care policy decision makers have searched for clear, unambiguous analyses to support difficult resource allocation decisions. Medical technology assessment (MTA) is of direct utility in this context. In MTA, 'technology' is not a term restricted to the description of apparatus only. On the contrary, the Office of Technology Assessment (OTA, 1978) defined 'Technology'; as 'the drugs, devices, medical and surgical procedures used in medical care, and the organisation and support systems within which such care is provided".

\section{Medical Technology Assessment: a comprehensive tool for policy makers}

Medical Technology Assessment (MTA) can be an important instrument to assist policy makers at different levels, such as government and its advisors, health insurance companies, hospital boards, clinicians and general practitioners, with regard to which, where and to what extent technologies should be provided. By evaluating new technologies in an early phase of their introduction, one can control the adoption and use (diffusion) of these developments, based on rational considerations. ${ }^{*}$ More and more, however, these techniques are used to inform decision makers about the efficiency of existing health care technologies. 
Technologies no longer considered as optinal might then be removed from the system. MTA involves the following aspects: medical effectiveness, socio-economic aspects (e.g. quality of life and convalescence), efficiency (cost-effectiveness), ethical, judicial and organizational aspects. ${ }^{5}$

The process of MTA can be described as a chain approach, which contains the following links:

- Signalling or identification of technologies which could be marked for technology assessment (TA).

- Priority rating of technologies for TA research.

- Testing of technologies through TA research.

- Synthesis of TA research results, which is the basis for policy recommendations.

- Diffusion of MTA knowledge to policy makers, insurers, health care suppliers and patients.

- Implementation of a technology and MTA information about this technology in common practice.

- Ultimately, evaluation of this technology in common practice.

\section{The role of Economic Evaluation}

Economic evaluation as part of MTA covers a range of techniques that can be used to investigate the costs and consequences of different procedures or programmes. The role of economic evaluation in the assessment process has gained more importance with time and has been more frequently applied since the 1960s. At present, the use of economic evaluation has been more or less formalized in several countries. The Health Care Financing Administration (HCFA) in the USA, for example is considering regulations to permit cost-effectiveness analyses in its coverage decisions ${ }^{8}$ and Oregon's Medicaid program (USA) originally proposed rationing publicly funded health care based upon cost-effectiveness analyses." In the final proposal of the Oregon allocation scheme, this original approach to the use of cost-effectiveness data has been more or less abandoned. In 1993, the US Public Health Service (PHS) appointed a panel of 13 scientists and scholars with expertise in cost-effectiveness analysis (CEA) to assess the current state of the science of CEA and to provide recommendations for the conduct of CEA studies in order to improve their policy relevance and utility. The Panel's work represents a consensus among many of the top researchers in the fields of economics, ethics, medicine, and outcomes measurement. ${ }^{10}$ In the US, the FDA mandates only that a technology needs to be tested for safety and efficacy before it is admitted to the market. With regard to the afford ability of a technology (Medicare), the Health Care Financing Administration takes a decision based upon the clinical effectiveness of the technology and not on cost-effectiveness data. Drummond ${ }^{11}$ has described how draft 
guidelines have been drawn up in both Australia and Canada that will require evidence on cost-effectiveness to be submitted together with evidence on safety and efficacy, as a condition for public reimbursement of drugs. In Australia, economic evaluations are now mandatory before new pharmaceuticals can be accepted under the Pharmaceutical Benefits Scheme, which provides a government subsidy on the price of listed drugs for purchasers. ${ }^{12}$ In the UK a madified form of economic evaluation has been a required part of NHS capital planning for several years now. ${ }^{13}$ With regard to the UK pharmaceutical market, there has been some pressure on the government to extend the precedent set by the Selected List to a national 'reimbursement' list or national formulary. The Parliamentary Select Committee on Health has supported this proposal (Health Committee 1994) ${ }^{14}$, arguing for a cost-effectiveness hurdle. All products would be automatically allowed on the list for the first 5 years after launch, but at the end of the 5-year period a decision would be made on subsequent listing, based on the cost-effectiveness of the products. Freemantle et al. ${ }^{15}$ argued that the UK should have an Australian/Canadian-style cost-effectiveness hurdle prior to any listing, but there has been opposition to this approach. ${ }^{16,17}$

In the Netherlands, a revolving National Fund for Investigational Medicine was created in 1988 by the Minister of Health, the Minister of Science and Education and the Sick Fund Council. ${ }^{18}$ Through this Fund the government annually supports clinical research in (new) medical technologies, for example, heart transplantation ${ }^{19}$ and dynamic graciloplasty as a new surgical treatment to cure fecal incontinence, with cost-effectiveness being an obligatory part of the assessment. ${ }^{20}$ The Dutch government has discussed the need for legislation on MTA, to assess new medicines, devices and screening and treatment procedures. The Dutch minister of Health, however, believes that a law on MTA is not necessary, since MTA is already implemented in several existing laws and procedures. However, the Minister recognized the importance of MTA as a tool for assessing efficiency within the Health Care sectors." 


\section{Techniques for Economic evaluation}

\section{Cost-benefit analysis}

Economic evaluation in the public sector was originally based on cost-benefit analyses. Cost-benefit analysis is an application of the theory of resource allocation, which is the core of Welfare-economics ${ }^{21}$, and was developed over half a century ago to assist public sector investment planning. Applications of cost-benefit analysis were used in the field of environmental protection. Cost-benefit analysis measures both costs and benefits in monetary units. The costs of a programme are measured as opportunity costs, which can be defined as the benefits of the best alternative programme. Benefits are defined as the maximum 'willingness to pay' (WTP) for the project. The WTP method calculates directly, or by inference, the amount individuals are 'willing to pay' to be in one health state versus another (or to avoid some specific level or risk). This method has great theoretical appeal to health economists, for it approaches the ideal of utility theory in that health states are valued by individuals in terms of preference. Using this instrument it is possible to make comparisons nor only among a wide range of technologies within the health care sector, but also between health care and other sectors. Cost-benefit analysis can therefore be used as an instrument to establish allocative efficiency of resources, provided that the costs and benefits of all alternative applications are known. Despite the enthusiasm for the WTP method, it has never really achieved an operational implementation, presumably because researchers have experienced difficulty in obtaining consistent values. ${ }^{22}$

The evaluation of costs and benefits of new technologies in the health care sector began about 35 years ago, and was dominated by economic costs of illness studies. Benefits were calculated as reduced treatment costs and reduced loss of production, a method known as the 'human capital approach'. In health care, however, it is difficult to assess all the benefits or effects in monetary units, such as clinical effects, quality of life or life-years gained. Furthermore, clinicians in practice, and health care workers in general, rely on more information than only a monetary value attached to a (new) technology or treatment. 


\section{Costeffectiveness analysis}

This shortcoming of the human capital approach and WTP led to the development of cost-effectiveness analysis (CEA). In a CEA, costs and effects of a new medical technology are measured in monetary and physical units, respectively. In general, costs and effects are studied from a societal perspective, with the consequences in and outside the health care sector being considered. CEAs are well suited to studies that focus on the comparison of a new technology with an existing alternative with homogeneous outcomes, for example, percentage of recurrences, diameter of stenosis and life years gained. However, in applying different 'effect' parameters, CEA is not helpful in making a rational choice between medical technologies that cover different health care areas. Therefore, CEA cannot be used as an instrument to establish the allocative efficiency which is aimed at in welfare economics theory. However, it can be a very useful instrument for clinicians and hospitals to decide which treatment option is preferred. Furthermore, State and Federal level decision makers with responsibility for Medicaid programs as well as public health systems may wish to know in which field investments of public money will have the largest impact in decreasing premature death from heart disease. A CEA that compares the cost per heart attack prevented by pharmacological treatment for elevated cholesterol, with population-based strategies (e.g. educational and regulatory initiatives) to change dietary patterns, addresses this type of question. A special version of the cost-effectiveness analysis is the cost-minimization analysis. In such an analysis, only the cost of the two alternatives are valued, while the consequences are considered to be identical in all relevant aspects. ${ }^{23}$

\section{Cost-utility analysis}

Some of the limitations of the CEA led to the development of a 'utility-based' measure of outcome. Utility refers to the subjective satisfaction people derive from consuming goods and services (e.g. health care). To measure this utility, various methods have been developed. ${ }^{24}$ Cost-Utility Analysis (CUA) was primarily developed in response to the desire to compare technologies that produce beterogeneous outcomes. By combining a 'utility" with life-years gained, a common unit of effectiveness, the Quality Adjusted Life Year (QALY), was constructed. ${ }^{25} \mathrm{By}$ combining effectiveness with costs, one can construct a 'cost per QALY' ratio. With a CUA it is possible to compare the "cost per QALY" of different interventions, provided that the same method to determine costs and utilities is used. This comparison has led to the construction of league rables for technologies in the health care sector. 
Table 3 Alternatives in Health Care presented in a League Table for the Netherlands

\begin{tabular}{lcr}
\hline Treatment & $\begin{array}{c}\text { Year of } \\
\text { presentation }\end{array}$ & $\begin{array}{r}\text { Cost/QALY } \\
\text { (in Dutch Guilders) }\end{array}$ \\
\hline $\begin{array}{l}\text { Influenza Vaccination } \\
\text { (group at risk) }\end{array}$ & 1987 & 2500 \\
CABG* & 1986 & \\
(angina pectoris 2) & & 15 to 20000 \\
(angina pectoris 3 or 4 and LMD) & 1988 & 3105000 \\
Cervixcancerscreening & & 26000 \\
(6 times yearly, 37.73 years) & 1988 & 65000 \\
Heart Transplantation & 1988 & 51 to 133000 \\
Liver Transplantation & &
\end{tabular}

${ }^{*} \mathrm{CABG}=$ coronary artery by-pass graft.

2*\% Exchange rate Durch Guilder:British Pound is approximately 2,50

Source: Oration by Prof. Dr. FFH Rutten on accepting the position of professor in Medical Technology Assessment at the Erasmus university of Rotterdam (1988)

Table 3 and 4 display two league tables, from Dutch and UK sources. The incremental benefits and costs of each technology are measured in relation to their most common alternative. 
Table 4 Quality adjusted life year (QALY) of competing therapies: some tentative estimates.

Cost/QALY

(E. Aug 1990)

Cholesterol testing and diet therapy only

(all adults, aged 40-69) 220

Neurosurgical intervention for head injury 240

GP advice to stop smoking 270

Neurosurgical intervention for subarachnoid haemorrhage 490

Anti-hypertensive therapy to prevent stroke (ages 45-64)

Pacemaker implantation 1100

Valve replacement for aortic stenosis 1140

Hip replacement 1180

Cholesterol testing and treatment 1480

CABG (left main vessel disease, severe angina) 2090

Kidrey transplant 4710

Breast cancer screening 5780

Heart transplantation 7840

Cholesterol testing and treatment of all adults aged 25-39 years

Home haemodialysis

CABG (1 vessel disease, moderate angina) 18,830

CAPD 19,870

Hospital haemodialysis 21,970

Erythropoietin treatment for anaemia in dialysis patients

(assuming a $10 \%$ reduction in mortality)

Neurosurgical intervention for malignant intra cranial tumours

Erythropoietin treatment for anaemia in dialysis patients (assuming no increase in survival)

126,290

Source: Drummond M, Torrance G, Mason J. Cost-effectiveness league tables: more harm than good? Soc. Sci. Med. 1993;37;1:33-40.

Currently, league tables are still incomplete and based on different methods of calculation. ${ }^{26}$ It is interesting in this context to note that a heart transplant in the UK is more than twice as efficient as a heart transplant in the Netherlands (corrected for the inflation rate and time difference). On the orher hand, the treatment of $\mathrm{CABG}$ (moderate angina) is almost 10 times as efficient in the Netherlands. Nevertheless, CUA and league tables are helpful in placing a technology in a broader context. An extension to the concept of league tables is the graph, designed by Laupacis ${ }^{27}$ (figure 1). 


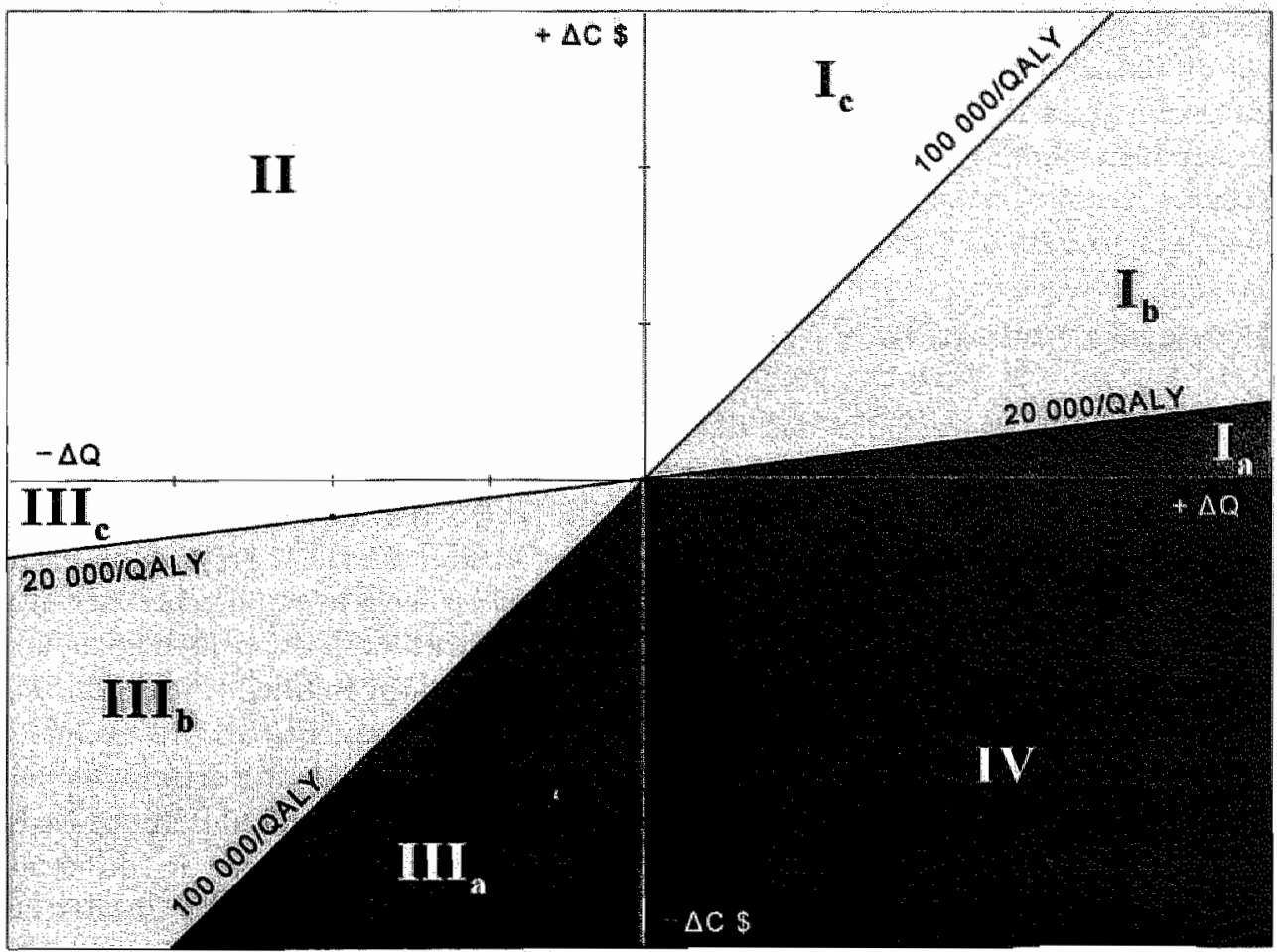

Figure 1: Grades of recommendation: Grade IV technologies should dearly be introduced or continued, and Grade II technologies should not be introduced or should be abandoned. Technologies in the upper right quadrant are more effective and more costly than their alternatives, whereas those in the lowrer lefr quadrant are less effective and less costly. Introduction of technologies in the upper right quadrant and abandonment of the technologies with the same shading in the lower left quadrant lead to similar degrees of cost-effectiveness.

Source: Laupacis A, Feeny D, Detsky AS, Tugwell PX. (1992) How attractive does a new technology have to be to warrant adoption and utilisation? Tentative guidelines for using clinical and economic evaluations. Canadian Medical Association Joumal $146: 473-481$.

Interventions do not always consist of the combination of incremental costs and extra benefits (QALYs). Some interventions combine cost savings with the production of extra benefits (QALYs): such combinations are preferred. Other technologies combine cost savings with reduction in health, in which case again the trade-off between money and QALYs is important. In this graph, the maximum willingness to pay for QALYS does play an important role. It represents the cut-off point between acceptable and non-acceptable health care. In this graph cost-effective technologies are those interventions that have a slope lower than the specific cut-off 
point. A huge problem is the uncertainty with regard to the specific value of this cut-off point. Laupacis ${ }^{27}$ expresses this uncertainty by introducing the boundaries of uncertainty. In the US and Canada the cut-off value between acceptable and nonacceptable technology, according to Laupacis ${ }^{27}$, lies between US $\$ 20,000$ and US $\$$ 100,000 .

\section{Economic evaluation, a valuable asset in MTA}

The concept of league tables and that of Laupacis ${ }^{27}$ are in themselves sound ideas and attractive to economists. However, it cannor be denied that huge gaps need to be bridged between the results of clinical trials, the context in which it is preferred that MTA is performed, and the resulting policy making on the aggregated level. It is increasingly acknowledged that QALY league tables have to be interpreted with care. Cost per QALY figures can only be compared with each other if the data are obtained using same method, a condition which is seldom fulfilled. Furthermore, clinical trials are performed in a specific hospital environment, by professionals with specific skills, in a specific region and country etc. The question arises whether these specific conditions are representative for the real world. Each difference leads to a deviation in real world cost per QALY-figure and therefore to different conclusions. Furthermore, league tables are always presented statically, while the underlaying technologies mostly are subjected to a highly dynamic process.

Does the above mean that CEA and CUA are not appropriate instruments for economic evaluation as part of technology assessment in health care? To answer this question the objective of the evaluation must be clearly defined. If policy makers are interested in the cost-effectiveness of alternative technologies in one clinical area, CEA and CUA are both a valuable part of the assessment. When a new medical technology is a substitute for, or a supplement to, an existing technology, which is already reimbursed and requires relatively little additional resources, this kind of evaluation can offer sufficient information. This is the case with, for example, laparoscopic cholecystectomy for patients with symptomatic gallbladder disease, which has largely replaced open cholecystectomy as the preferred treatment. However, decision-making becomes more complicated if a medical technology levies considerable additional constraints on resources within a given health care budget. In that case, information obtained from the above-mentioned instruments is necessary, but not sufficient to provide full information with regard to the appropriate use of, and choices among, health care facilities. ${ }^{4}$

Economic evaluation, as described above, focuses on efficiency. If the health gain from adding a pound's expenditure to one type of activity exceeds the health loss from taking that pound away from another type of activity, the former is more efficient than the latter, and overall health justifies that transfer. The equity 
counterpart is that resources ought to be distributed in proportion to need in all circumstances where the resources avallable are insufficient to meet all needs. Efficient resource allocation may clash with the equitable allocation, and it is a well known fact that a tradeoff between equity and efficiency may have to be made. ${ }^{28}$

The following illustration shows how efficiency, from a normative economical point of view, clashes with an aspect of equity: ability to pay. "To argue that health care, like food and housing, ought to be rationed by ability to pay is purely a moral judgement. As such, it is not wrong. But surely it would be appropriate, in a democracy, to debate this important question more explicitly than it has been debated in the normative theory of welfare economics. There is an argument that a market-based health system, in which individuals are granted responsibility for their own health care (and their own health status), and in which individual consumers are empowered to exercise free choice of the consumer good, would result in health care becoming more 'efficient' (and from an economic point of view 'better') than any alternative system, and that it would obviate the need for 'rationing' health care. This would lead to rationing by income class' (Prof. Dr. Uwe Reinhardt at the international Health Economics Association Conference in Vancouver, BC, Abstracts, May 1996). ${ }^{29}$

\section{Conclusion}

We have to keep in mind that economic evaluation is not the only criterium on which policy makers have to base their judgements. Medical Technology Assessment covers a wide spectrum of evaluations and considerations and therefore reaches far beyond calculation of 'costs per QALY or "cost per effect' only.

\section{References}

1 Rubenstein ES. (1994) Comparative spending of governments. "The right data. New Xork: National Review Books.

2 Bellien P.(1996) Healthcare Reform in Europe. PharmacoEconomics 10;2:94-99.

3 Office of Technology Assessment (1978) Assessing the efficacy and safery of medical technologies. Government Printing Office, Washington, DC, USA.

4 Adang EMM, Dirksen CD, Engel GL, Baeten CGMI. (1995) Medical technology assesment: economic evaluation of new technologies. British Journal of Hospital Medicine 53;11:563-566.

5 Banta HD, Luce BR. (1993) Health Care Technology and its Assessment. Oxford University Press, Oxford.

6 Letter of the Dutch minister of HealthTweede Kamer (1995), vergaderjaar 1995-1996, 24 126, nur. 9. 
7 Elixhauser A, Luce BR, Taylor W, Reblando J. (1993) Cost benefir and cost effectiveness analyses from 1979 to 1990: A bibliography. Medical Care 31(S):1-149.

8 Luce $\mathbb{B R}$, Brown $\mathbb{R E}$. (1995) The use of technology assessment by hospitals, health maintenance organisations, and third-party payers in the United States. International Journal of Technology Assessment in Healuh Care 11:1:79-92.

9 Strosberg MA, Wiener JM, Baker R, Fein IA, eds (1992) Rationing America's medical care:the Oregan plan and beyond. The Brookings Institution Washington, DC.

10 US Department of Health and Human Services, Public Healuh Service. (1996) Cast-effectiveness in Health and Medicine. Oxford University Press.

11. Drummond MF. (1992) Cost-effectiveness guidelines for reimbursement of pharmaceuticals: Is economic evaluation ready for its enhanced status? Health Economics 1:85-92.

12 Salkeld G, Davey P, Arnolda G. (1995) A critical review of health-related economic evaluations in Australia: implications for health policy. Health Policy 31:111-125.

13 Robinson R. (1993) Economic Evaluation and Health Care: "The policy context. BMJ 307:994996.

14 Health Committee. (1994) Priority setting in the NHS: the NHS drugs budget, Vol.I, report. House of Commons Session 1993-94;HMSO.

15 Freemantle N, Henry D, Maynard A, et al. (1995) Promoting cost effective prescribing. BMJ 310:955-6.

16 Department of Health. (1994) Government response to the Second Report from the Health Committee. House of Commons Session 1993-1994;HMSO.

17 Towse $\mathbb{A}$, Wells $\mathbb{N}$. (1995) Cost-effectiveness studies may not be cost-effective[letter]. BM] 126:311.

18 Bos M. (1994) Health care technology in the Netherlands. Health Policy 30:207-255.

19 van Hout B, Bonsel G, Habbema D, van der Maas P, de Charro F. (1993) Heart transplantation in the Netherlands; costs, effects and scenarios. Journal of Health Economics 12:73-93.

20 Baeten CGMI, Geerdes BP, Adang EMM et al.(1995) Anal dynamic graciloplasty in the treatment of intractable fecal iricontinence. $\mathrm{N}$ Engl J Med ;332:1600-1605.

21 Mishan EJ. (1988) Cost-benefit analyses. Fourth edition. Routledge, London.

22 Stalhammar N. (1996)An empirical note on willingness to pay and starting point bias. Med Decis Making 16:242-247.

23 Drummond MF, Stoddart GL, Torrance GW. (1987) Methods for the economic evaluation of health care programmes. Oxford University Press.

24 Froberg. DG, Kane RL (1989) Methodology for measuring health-state preferences-II:scaling methods. J Clin Epidemiol 42, 5:459-471.

25 Williams A. (1985) Economics of coronary artery bypass grafting. BM] 291:326-329.

26 Drummond MF, Torrance $G$, Mason J. (1993) Cost-effectiveness league tables: more harm than good? Soc. Sci. Med. 37, 1:33-40.

27 Laupacis A, Feeny D, Detsky AS, Tugwell PX. (1992) How attractive does a new technology have to be to warrant adoption and utilisation? Tentative guidelines for using clinical and economic evaluations. Canadian Medical Association Journal 146:473-481.

28 Culyer AJ. (1992)The morality of efficiency in health care-some uncomfortable implications. Health economics $1: 7-18$. 
29 Reinhardt UE. (1996) The new social contract for health care should economists write it or merely describe it? Abstracts, International Health Economics Association Inaugural Conference on quality and inequality, what care, whose costs, whither health. Vancouver, $\mathrm{BC}$, May 19-23. 


\section{Surgeon and Economist together in a Study: A win-win Situation!}

This chapter was originally published under the title:

Surgeon and economist together in a study: a win-win situation! G. L. Engel. E. M. M. Adang and G. Kootstra. In Ökonomie und Chirurgie: Konsens oder Dissens? Effektivität und Ökonomie Chirurgischen Handelns, E. Neugebauer und H. Troidl, Georg Thieme Verlag, Stuttgart-New-York pp: 16-21. 


\section{Introduction}

The purpose of this chapter is to demonstrate that in Medical Technology Assessment (MTA) clinicians (e.g., surgeons) and other scientists (e.g., economists) have to cooperate closely together, and, by doing so from the beginning of a project, may arrive at unforeseen, but important, results. The need for multidisciplinairy cooperation, which is imposed by the need for multiple endpoints in evaluation research (such as: clinical effectiveness, quality of life, costs, etc.), turns out to be a potentially profitable investment.

The office of Technology Assessment of the United States defined 'Technology' as: "the drugs, devices, medical and surgical procedures used in medical care, and the organization and support systems within which such care is provided" 1,2

One of the obvious, and important, aims of MTA is to provide comprehensive information to government and its advisors, hospital directors, financing agencies, clinicians, and every one who plays a role in defining policies. MTA can therefore be very important to direct the diffusion of new technologies and to allocate the budgets for it. However, the aims of M'T'A go further: its results are instrumental in finding the correct indications for new treatments and, sometimes, to adjust protocols.

The central incentive for MTA is to evaluate results, always from multiple viewpoints. Therefore, a thorough design for the study and a good methodology are prerequisites. This is one of the hidden advantages of MTA, because of the multi-disciplinary approach and the multiple end points it can only function in an atmosphere of very critical appraisal and review of the outline for research. It is obvious that clinical research itself will be the first to gain from this setting.

In this chapter, the issue of synergism between disciplines in a MTA-context will be demonstrated with 2 examples from surgery in the Netherlands. One is a large MTA of heart transplantation, performed in recent years, and the second is a MTA of Dynamic Graciloplasty for faecal incontinence. The main research questions at the beginning of both studies and the main answers obtained will be schematically presented. We will however concentrate on some of the unexpected extras, the spin offs, which both studies yielded (Table 1). 
Table 1 Surgeon and Economist together 2 examples of MTA-studies in the Netherlands

\begin{tabular}{|c|c|c|c|}
\hline & Questions & Answers & Spin off \\
\hline $\begin{array}{l}\text { Heart } \\
\text { Transplantation }\end{array}$ & $\begin{array}{l}\text { Effectiveness of HTX } \\
\text { Surgical procedures } \\
\text { lndications } \\
\text { \#atients } \\
\text { \#onor hearts } \\
\text { Organization, \# } \\
\text { centres }\end{array}$ & $\begin{array}{l}\text { HTX routine, good } \\
\text { results } \\
\text { Indications clear } \\
\text { Need }>150-200 / Y \\
\text { Donors max. } 80 / \mathrm{Y} \\
\text { Cost } 57000 \mathrm{Df} / \mathrm{Y} \\
2 \text { (or } 3 \text { ) centres }\end{array}$ & $\begin{array}{l}\text { Dispute about "stage } \\
\text { of disease" } \\
\text { Patient selection not } \\
\text { major problem } \\
\text { Model for budget } \\
\text { allocation }\end{array}$ \\
\hline $\begin{array}{l}\text { Graciloplasty for } \\
\text { faecal incontinence }\end{array}$ & $\begin{array}{l}\text { Effectiveness of } \\
\text { neurostimulated } \mathrm{M} \text {. } \\
\text { Gracilis } \\
\text { Quality of life } \\
\text { before/after } \\
\text { operation } \\
\text { Cost-effectiveness }\end{array}$ & $\begin{array}{l}73 \% \text { successful } \\
\text { Quality of life } \\
\text { increases after success } \\
\text { Quality of life } \\
\text { decreases only } \\
\text { temporarily after } \\
\text { falure } \\
\text { Cost of operation: } \\
55000 \text { Dfl; } \\
\text { conventional: } 21500 \\
\text { Dfl. }\end{array}$ & $\begin{array}{l}\text { Content } \neq \text { continent } \\
\text { learning curwe } \\
\text { Effects of technical } \\
\text { failure } \\
\text { Indication, } \text {, patients, } \\
\text { \# centres } \\
\text { Serisitivity nnalysis } \\
\text { Cost of stoma care } \\
\text { Adaptation }\end{array}$ \\
\hline
\end{tabular}

\section{MTA of Heart Transplantation in the Netherlands}

\section{Questions}

- What is the state of science in heart transplantation (HTX)?

- Surgical procedures? Immune suppression? Psycho-social help?

- Indications for HTX and selection criteria? Number of patients.

- Availability of donor hearts?

- Hospital organization, facilities and resources, number of centres.

In December, 1983 the Dutch Government raised a request for advice to the Health Council of the Netherlands about the state of science in heart transplantation, more specifically about the surgical procedures, the need for immune suppression and psycho-social help after the transplantation, the expected number of donor hearts and the optimal hospital organization, such as the facilities and resources. Also the Government requested advice on the optimal number of heart transplantation centres in the Netherlands. Accordingly, the Health Council installed a committee of experts, which produced a provisional report after 7 months and, in early 1989 , a comprehensive final report (Health Council, 1989). ${ }^{3}$ 
At the same time, a MTA study was commissioned to investigators from Erasmus University, Rotterdam. This study ${ }^{4,5}$ was financed by the Health Insurance Execurive Board, an important office in the Netherlands. Its main task is to supervise the sick funds. In later years, this Board was very instrumental in stimulating the "Fund for Investigational Medicine'. Today, this Fund is one of the main drivers and sources for MTA in the Netherlands. Although each of the parties involved in the evaluation of heart transplantation in the Netherlands had its own role, in retrospect it can be said that the close contacts between actors in the evaluation have been very fruitful. Those contacts were institutionalized in designated working groups, committed to direct or advice the investigators.

\section{Answers}

- HTX can be regarded as a routine-intervention. Results are good: I-year survival $90 \%$, 5-year survival $70-80 \%$. Quality of life after successful HTX is good.

- Indications (= diagnoses) for HTX are generally agreed upon.

- Number of Donor hearts in the Netherlands: max. about 80/year.

- Need for HTX in the Netherlands: 150-200 (age: 10-55!)

- Cost per life year gained fl. 57 650, Cost per QALY: fl. 71900,-

- In the Netherlands 2 (or 3) centres.

As would perhaps be no surprise with the present knowledge, it was concluded (in 1988/89) that heart transplantation can be regarded as a save and effective intervention and that the surgical procedure is standard. The patient survival results were good, the graft survival was perhaps not as good as some had stated in the early 80 's, but still very acceptable. A new element was the outcome of the quality of life study, which showed that the difference in quality of life before and after the transplant was impressive. The increase in quality of life can be maintained in later years. This effect turned to be one of the leading arguments in favour of a positive decision with regard to facilities and resources provided by the government.

International general agreement about the diagnoses leading to an indication for heart transplantation could be shown, thereby resolving one of the problems as seen at that time by policy makers. Calculations about the potential number of available donor hearts in the Netherlands were produced. The expected need for donor hearts, however, could be shown to exceed the available number, even with very restricted medical indications for transplantation and with assumptions on very strict limitations to the age of the potential receiver.

Interestingly, the studies showed that the costs per transplant, calculated per life year gained or per quality adjusted life year (QALY) gained were moderate. Although the amount of money needed is not small, it compares favourably to other, accepted, therapies, such as haemodialysis. There was hardly any discussion 
about the cost issue after the publication of the reports. Since the early 80 's many policy makers thought that heart transplantation would be excessively costly. The insight in costs of HTX was really remarkable, for that it showed how the results of MTA can shift the object of discussions.

\section{Spin-offs}

- Dispute about "optimal" stage of disease for HTX remains.

- As part of the MTA, a study towards ethical aspects of patient selection was started: "how to organize a just and effective program confronted. with a large shortage of donor hearts?" "The study resulted in an analysis and consideration.

- Patient selection ("yes or no age criteria?") is a formally unsolved problem. However, intensive ethical discussion led to a (State-approved) protocol (January, 1989).

- At present in the Netherlands relatively few deaths on the waiting list.

- A cost model was developed, accounting for all (major) costs per patient, including (life long) medical care after transplantation.

As part of the technology assessment, a study into the ethical aspects of patient selection was started. ${ }^{6}$ The study dealt with the question: Is it possible to organize a just and effective program, when confronted with a large shortage of donor hearts, and in view of the impossibility of having your patients on waiting lists very long? This study presented many principles and potential solutions; in fact 12 different scenario's were examined (Table 2). Here and now, we will not comment on the backgrounds of each of these scenarios. They are being listed as an example of the character of the results arrived at.

One of the potential solutions, namely to maintain very tight age limits (more strict than between age 10 and 55), was seen as unethical. Although a formal solution of the problem of scarcity of donor hearts was not reached, it is interesting to note that at present in the Netherlands there are no large waiting lists for HTX and relatively few deaths on the waiting list, acceptable transplantation results and little discussion about the medical indications. The Dutch government approved a medical protocol put forward by the centres involved in HTX, after advice from its advisory commissions, which is still being used.

It may be concluded that the ethical study, although it did not result in formal rules, apparently yielded so much insight in relevant principles and considerations that now an informal and very effective status quo exists in the Netherlands (Table 2). 
Table 2 Ethical Analysis: Scarcity of donor hearts for transplantation: Comparison of 12 scenario"s

\begin{tabular}{|c|c|c|c|}
\hline Solution & $\begin{array}{l}\text { Implemen- } \\
\text { tation? }\end{array}$ & Problem solved? & Desirable? \\
\hline $\begin{array}{l}\text { 1 Make referral of patients for } \\
\text { HTX more difficult } \\
\text { (=decrease demand') }\end{array}$ & perhaps & partly & no \\
\hline $\begin{array}{l}2 \text { Restriction of the medical } \\
\text { indication (e.g., onlyt } \\
\text { myocardiopathy) }\end{array}$ & perhaps & probably & no \\
\hline $\begin{array}{l}3 \text { Age restrictions (e.g., only } 10 \\
50 \text { years of age) }\end{array}$ & yes & yes & no \\
\hline $\begin{array}{l}\text { 4. Other non-medical selection } \\
\text { criteria (e.g.; only those } \\
\text { patients with a very supportive } \\
\text { family) }\end{array}$ & hardly & $\begin{array}{l}\text { in theory, } \\
\text { perhaps }\end{array}$ & no \\
\hline 5 More donor hearts & $\begin{array}{l}\text { takes many } \\
\text { efforts }\end{array}$ & partly & yes \\
\hline 6 Xenotransplantation & not yet & yes & may be \\
\hline 7 Permanent artificial heart & no & yes & not probable \\
\hline 8 Alternative treatments & not yet & unknown & unknown \\
\hline $\begin{array}{l}9 \text { Primary prevention of serious } \\
\text { heart diseases }\end{array}$ & no & unknown & unknown \\
\hline $\begin{array}{l}10 \text { No HTX at all in the } \\
\text { Netherlands }\end{array}$ & yes & hardly & no \\
\hline $\begin{array}{l}11 \text { Very strict selection } \\
\text { procedures (- extensive } \\
\text { protocol + control } \\
\text { mechanisms) }\end{array}$ & $\begin{array}{l}\text { takes many } \\
\text { efforts }\end{array}$ & partly & perhaps \\
\hline 12 Restrictive budget for HTX & no & no & no \\
\hline
\end{tabular}

A second peculiarity of the MTA study is the cost model. The researchers succeeded in analysing the cost aspects in such a way that they could construct a model, in which the lifelong costs of heart transplantation, including the expensive medication and the follow up, were included (Figure 1). 
costs ( $x$ NLG 1,000)

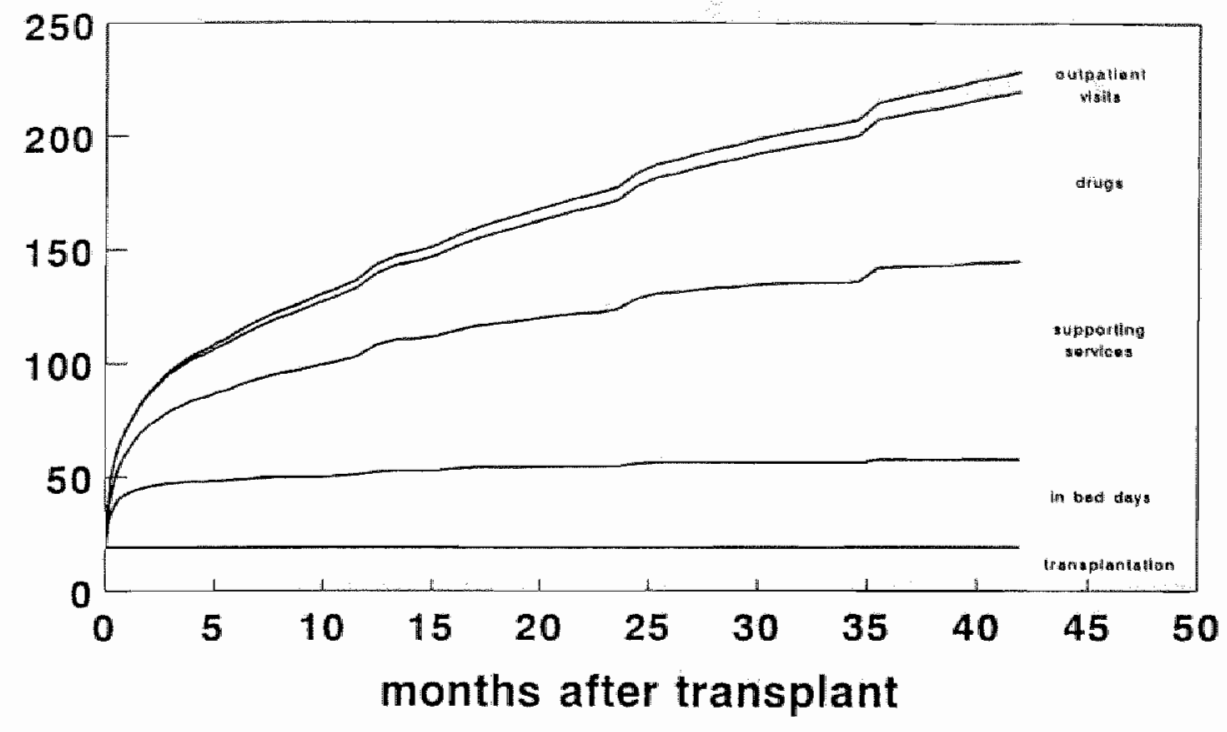

Figure 1 Cumulative costs after tramsplant. Sum-Limit estimates (per patient)

Source: Hout BA van, Bonsel G, Habbema D, van der Maas P, De Charro E. Heart transplantation in the Netherlands; costs, effects and scenarios. Journal of Health Economics (1993) 12: 73-93.

By doing so, it was possible to calculate the realistic cost of the entire programme. This part of the study appeared to yield much confidence from the policy makers in that they had not to fear extra bills later. Also they were able to make reservations for later years. This is of practical importance, since with a constant annual number of transplantations the total costs increase for a long period. The same model, based on several assumptions (consistent indications, 80 donor hearts per year after a starting period, constant procedures, etc.), is able to summarize the gain in number of patients alive with and without a HTX-programme (Table 3). 
Table 3 Nwmbers of heart transpllants and patients alive per year (ultimo): with and without transplant programme

\begin{tabular}{c|cc|cc}
\cline { 2 - 5 } & \multicolumn{2}{|c|}{$\begin{array}{c}\text { With transplant } \\
\text { programme }\end{array}$} & Without transplant programme \\
\cline { 2 - 5 } & Transplants & Patients alive & Transplants & Patients alive \\
\hline 1988 & 48 & 127 & 0 & 48 \\
1992 & 72 & 356 & 0 & 131 \\
1996 & 80 & 564 & 0 & 152 \\
\hline 1999 & 80 & 693 & 0 & 159 \\
\hline
\end{tabular}

\section{Dynamic Graciloplasty}

\section{Questions}

- Effectivity of a neurostimulated transposed skeletal muscle (M. Gracilis) as an anal sphincter in patients with faecal incontinence.

- Quality of life before and after Dynamic Graciloplasty.

- Cost-analysis of this surgical treatment as compared with conservative management.

The dynamic graciloplasty for faecal incontinence is a more recent innovation and probably relevant for a much greater number of patients than heart transplantation. In animal studies and in clinical experiments the technical feasibility of the transposition of the Gracilis muscle as an anal sphincter was demonstrated, when in a second operation a stimulator was implanted which tunes the muscle so that it can maintain a tonic contraction. An external magnet gives control over its release. The Health Insurance Executive Board granted an "Investigative Medicine' study to the University Hospital Maastricht during the period 1991 - 1994. The evaluation included the medical and psycho-social aspects (e.g., quality of life study), as well as the cost analysis. ${ }^{7,8,9,10,11,12}$ 


\section{Answers}

- The "Investigative Medicine" study started as a multi-disciplinary, prospective, protocol. Surgeon and economist work closely together from the beginning of the study.

- The treatment is successful: $73 \%$ of the operations yield cont(in)ent patients.

- Quality of life in the successful group increases, quality of life in the unsuccessful group does not change significantly, only slight temporarily changes were noticed.

- Costs of dynamic graciloplasty for faecal incontinence, given several assumptions, for example, with regard to future replacement of the neurostimulator, is about 55000 Dutch guilders, while an estimate of the costs of "no therapy" (e.g, conventional management) is about half and the colostomy alternative is about twice as expensive.

In this protocol surgeons and economist work closely together from the beginning of the study. Although the study period with regard to 'Investigative Medicine' has finished, the Dynamic Graciloplasty operating series still increase. At this moment one can state that more than $73 \%$ of the operations are successful. Success is determined by several end points, for example, manometry and enema tests, but also on the basis of Quality of life interviews taken from the patients. Quality of life increases significantly after successful operation. In addition we now also know how the patients in which the operation failed, judge their situation. Quality of life decreases only temporarily and only in some of the dimensions of the multidimensional quality of life concept..$^{p, 10,11}$

Cost estimates show that Dynamic Graciloplasty is more costly than doing nothing, that is: conventional management. It is also shown that Dynamic Graciloplasty is less expensive than the colostomy alternative.

The Dutch Health Insurance Executive Board gave its recommendation to the Minister of Health about Dynamic Graciloplasty. The Board stated that the investigated treatment was efficacious for the investigated indications and should be considered for reimbursement. Furthermore, the Board advised, based on aspects like quality, experience, costs, indication and patient supply, that the provision should be restricted to a limited number of specialized colorectal departments. 
Spin-offs

- Learning effects.

- Estimated annual number of patients, necessary resources + facilities in the hospital, number of designated centres in the Netherlands.

- Difference "content-continent".

- Sensitivity of cost for: number of replacements, cost of pacemaker, discounting.

- Quality of life instrument.

- Insight in the costs of stoma-care.

- The influence of adaptation on quality of life measurement.

Learning effects were detected in operation time, antibiotic management and more recently in operating procedure (two step procedure versus one step procedure). Taking into account these learning effects, as well as analyses on the indications, and the possible number of patients, we were able to provide information whether or not it is advisable to concentrate this new treatment in only a small number of surgical centres with the necessary infrastructure available. Such results are relevant to policy makers and to hospital administrators. The organizational aspects are, however, equally important for the clinicians.

Sensitivity and scenario analyses provide us with detailed economic information, such as break-even analyses, future costs, and economic life time of the neurostimulator. Also it gives insight in the life long costs of Dynamic Graciloplasty.

Quality of life gives standardized opinions about the value of the dynamic graciloplasty, compared to alternative treatments. It also clarifies the distinction between "content" and "continent".

Furthermore, the cost analysis gives insight in the costs of an alternative to Dynamic Graciloplasty, Colostomy. Patients undergoing a Colostomy have a stoma at the abdominal side, which generates life long costs of stoma-care.

With regard to quality of life measurement the effect of adaptation was noticed. This resulted in heightened pre-operative quality of life scores, resulting in only little possible increase after successful operation.

\section{Conclusions}

An important tool for medical technology assessment is an outstanding research design. There is an excellent opportunity to incorporate the thought of 'evidence based medicine" into MTA. On one hand this is a labourious investment for a 
multidisciplinairy study. On the other hand every worthwhile idea for clinical research deserves a well-thought protocol.

Therefore the technology assessment approach has great advantage for dinical research. It leads to multiple end points in one and the same study, including quality of life and costs. Cost studies are not necessarily a nuisance for clinicians, but can be very instrumental instead.

Basic in good cost studies is good registration of volumes and prices. Very important, but more difficult, are good prognoses of future costs. Especially for this, cooperation between clinician and economist is indispensable. The economist in the MTA-team must be responsible for the relevant sensitivity analyses and scenario models. The value of future effects, such as the quality of life gained and the expected upcoming costs, may be strongly dependent on the discount rate at which both costs and effects are discounted to present values. This technique, well known in economics, is a method to assign present value to future events.

As far as quality of life is concerned, it is not only the importance for the evaluation which counts: we now have seen many cases in which the quality of life study yielded results of practical interest for directing psycho-social help for the patient after the intervention. It also gave important information for the patient when considering to accept the treatment. MTA can be a good instrument to underline learning effects, and to analyse the necessity of resources and infrastructure. Last but not least, MTA is indispensable to feed research results into policy decisions.

\section{References}

1 Office of Technology Assessment. Assessing the efficacy and safety of medical technologies. Washington, D. C., U. S. A. Government Printing Office, 1978.

2 Banta HD, Luce BR. Health Care Technology and its Assessment. Oxford University Press, 1993. ISBN 0-19-262297-8.

3 Health Council of the Netherlands, Advice on Heart Transplantation, 1989. (in Dutch, with a Summary in English) [Advies harttransplantatie, Gezondheidsraad 1989/2, "s-Gravenhage 27-02-1989].

4 Hout BA van. Harttransplantaties, kosten, effecten en prognoses. Dissertation 1990, Erasmus University Rotterdam (in Dutch, with a Summary in English).

5 Hout BA van, Bonsel $G$, Habbema $D$, van der Maas $\mathbb{P}$, De Charro E. Heart transplantation in the Netherlands; costs, effects and scenarios. Journal of Health Economics (1993) 12: 73-93.

6 Engel GL, Kastelein WR. Selectie van patiënten; achtergrondstudie behorend bij het Advies Harttransplantatie, Gezondheidsraad 1989/A1 (in Dutch) 
7 Baeten CGMI, Konsten J, Spaans $F$, et al. Dynamic graciloplasty for treatment of faecal incontinence Lancet (1991) 338:1163-5.

8 Konsten J. Dynataic musculoplasty A new perspective for treatment of faecall incontinence. Dissertation 1993, University of Limburg.

9. Adang EMM, Engel GL, Konsten J, Baieten CGML Quality of life after dymamic graciloplasty for faecal incontinence: first results Theoretical Surgery (1993) 8: 122-124.

10 Adang EMM, Engel GL, Konsten J, Baeten CGMI. Quality of life after dynamic graciloplasty for faecal incontinence. 11. Arbeitstagung der Chirurgischen Arbeitsgemeinschaft Studien (CAS) der Deutschen Gesellschaft für Chirurgie, Porsdam. 05-06 November 1993.

11 Baten CGMI, Geerdes BP, Adang EMM, et al. Anal Dynamic Graciloplasty in the treatment of intractable fecal incontinence. N Engl J Med. (1995) 332:1600-1605.

12 Adang EMM, Engel GL, Rutten FFH, Geerdes B, Baeten CGMI. Cost-effectiveness of Dymamic Graciloplasty in patients with fecal incontinence. In press Dis Colon Rectum. 


\section{Quality of life after dynamic graciloplasty for fecal incontinence}

Parts of this chapter were originally published under the titles:

Quality of life after dynamic graciloplasty for faecal incontinence: first results. Adang EMM, Engel GL, Konsten J, Baeten CGMI. Theor. Surg 1993; 8: 122-124.

Anal Dynamic Graciloplasty in the treatment of intractable fecal incontinence. Baeten CGMI, Geerdes BP, Adang EMM, Heineman E, Konsten J, Engel GL, Kester ADM, Spaans F, Soeters PB. N Engl J Med. 1995;332:1600-1605.

Final report Developmental Medicine Project 91/066. De Dynamische Gracilis Plastiek een nieuwe behandeling voor fecale incontinentie. Deelrapport: kwaliteit van leven. Adang EMM, Geerdes B, Engel GL, Baeten CGMI. Ziekenfondsraad, September 1994. 


\section{Introduction}

Fecal incontinence is a problem that substantially diminishes a person's quality of life. ${ }^{1,2}$ Data from Great Britain report a community prevalence of 4.2 men and 1.7 women per 1000 people who are 15 to 64 years of age, and of 10.9 men and 13.3 women per 1000 people who are 65 or older. "The prevalence of persistent fecal incontinence in the United States has been reported to be 2.3 percent." Treatment methods such as a change of diet, the use of constipating agents or daily enemas, and training in biofeedback can often be effective. However, when conservative treatment fails, surgical treatment, including the creation of a colostomy, has been used with varying success concerning quality of life, ${ }_{s}^{1,6,7,8}$

Since 1952 a surgical treatment is the construction of a neosphincter around the anal canal with the gracilis muscle." The results of this procedure have been disappointing ${ }^{10}$, mainly because this muscle is dependent on volition, and thus a sustained contraction is not possible. Because of muscle fatigue due to a preponderance of type II muscle fibres, this skeletal muscle can only provide forceful contractions for a short time. "In case of success of this transposition of the gracilis muscle, this can probably be explained by a tightening of the anal canal. ${ }^{12,13}$

Studies in animals and clinical investigations have shown that the results of graciloplasty were improved by electrical stimulation administered by implanted electrodes and a pulse generator. ${ }^{14,15}$ The stimulator replaces voluntary contraction and exerts a sustained contraction ${ }^{16,17}$ that leads to the transformation of type II fatigue-prone muscle fibres into type I fatigue-resistant fibres. ${ }^{18,19}$ Electrical stimulation gives the transposed gracilis muscle the properties required to function as a sphincter. ${ }^{20,21}$ This is a new and revolutionary approach to fecal incontinence, and it is called the dynamic graciloplasty. 


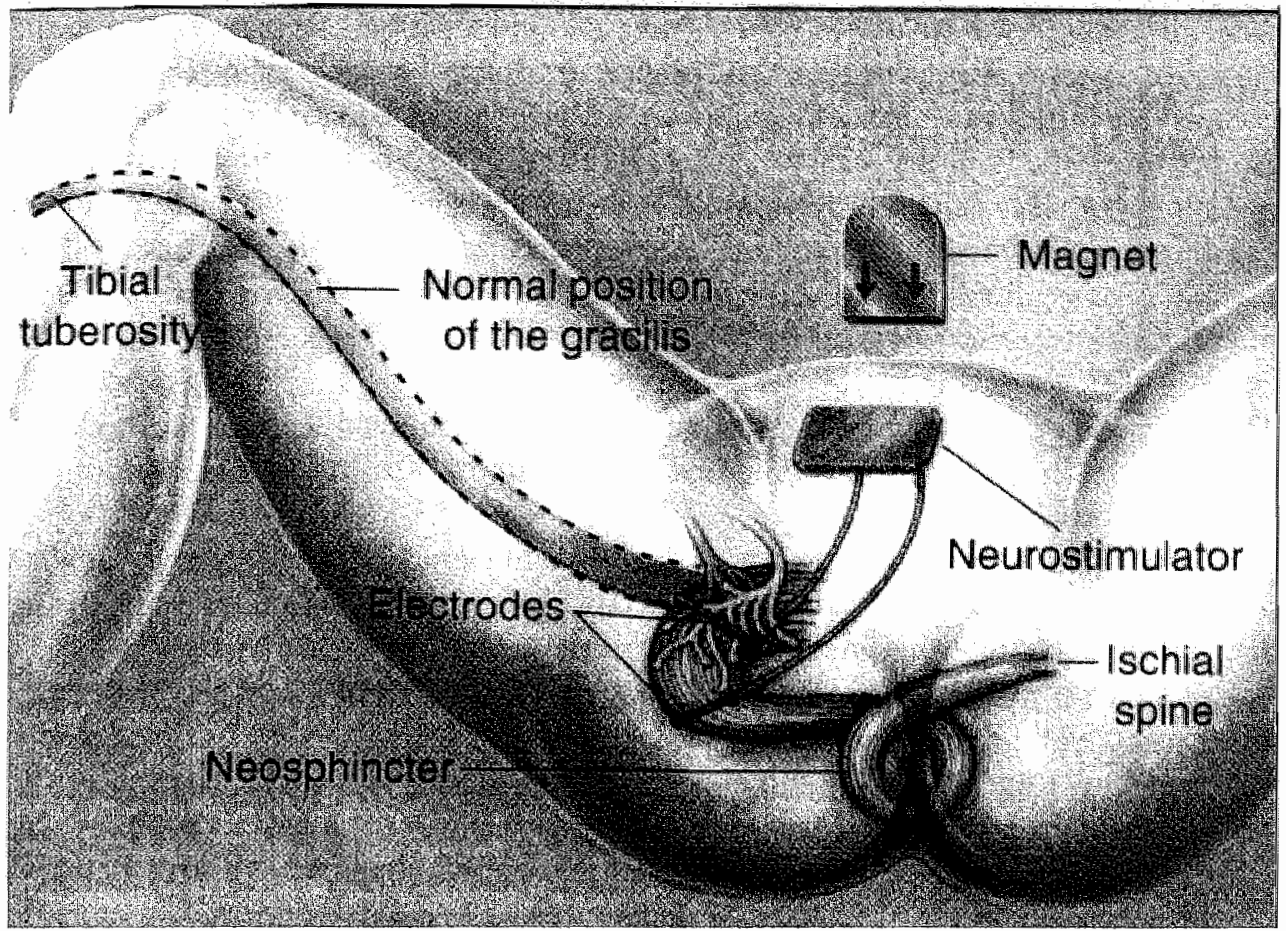

Figure 1 Configuration of the Anal Dynamic Graciloplasty

The procedure is displayed in figure 1. The gracilis muscle is mobilized to its insertion at the tibial tuberosity and the tendon is there divided. Proximally, the neurovascular bundle is left intact, and the muscle is transposed around the anal canal and fixed to the ischial spine (according to the method of Pickrell et. al. ${ }^{\text {, }}$, with slight modification $\mathrm{s}^{20}$ ). Six weeks later intramuscular electrodes are implanted at the site of nerve entry and connected through a subcutaneous tunnel to a neurostimulator, placed in the abdominal wall.

Fecal incontinence influences the quality of life in patients affected. ${ }^{1,5,6,7,7,8}$ Unsatisfactory fecal continence is commonly related with social and sexual problems. ${ }^{1}$ In patients with incapacitating fecal incontinence, who have an absent or enervated anal sphincter, and for whom therapy with drugs or behavioural adaptation is generally unsatisfactory, gracilis muscle (a muscle with a function in the upper leg) transposition around the anal canal" and subsequent implantation of electrodes and a pulse generator can be a solution. ${ }^{16,17,22}$ Patients with this dynamic graciloplasty use an external magnet to turn the pulse generator "off" to permit defecation at a suitable moment. ${ }^{16,17,22}$ 
Anal dynamic graciloplasty is a new, invasive and relatively expensive technique aiming to treat incontinence. An evaluation in a broader than the surgical perspective is indicated. The effectiveness of a new surgical treatment modality such as dynamic graciloplasty can be assessed, using a health related quality of life measurement. It is generally recognized that health-related quality of life comprises complex, multidimensional factors. ${ }^{25}$ Also quality of life should be assessed on a patient-oriented basis (contrary to, e.g., doctor's opinion or general society's opinion).

The purpose of this study was to examine the procedure 'dynamic graciloplasty' according to the patient's interpretation of his state of 'Quality of Life' before and after the intervention.

The hypothesis to be investigated was: does dynamic graciloplasty improve "quality of life" in patients with fecal incontinence compared to conventional therapy (using diapers, enemas' and other incontinence materials as well as special diets).

To conduct valid quality of life studies, a cleat definition of quality of life, broadly accepted and understood by those doing quality of life research, is essential. A concept which is gaining acceptance, defines quality of life operationally by patients" perception of performance in four areas: physical and occupational function, psychological state, social interaction, and somatic sensation. A pragmatic definition of quality of life, that emphasizes the day-to-day comings and goings of a free, living individual is the following: quality of life represents the functional effect of an illness including therapy upon a patient as perceived by the patient. ${ }^{24}$

Domains of quality of life $e^{24}$

1 Physical and Occupational Function

Questions about strength, energy, and the ability to carry on expected normal activities are typical questions asked. Questions should elicit responses uninfluenced by age, sex, or by geographical habitus.

\section{Psychological Function}

Of the many psychological parameters that have an impact on quality of life, those studied most are anxiety, depression, and fear. The psychometric measures employed in quality of life studies may be simple questions inquiring directly as to mood, anxiety, or depression, or they may be more sophisticated borrows from the large psychometric testing literature. 


\section{Social Interaction}

This refers to a patient's ability to carry on the person-to-person interactions that form the core of communal living (family, close friends, work and the generall community).

\section{Somatic Sensation}

Somatic Sensation encompasses unpleasant physical feelings which may detract from someone's quality of life (pain, nausea, and shortness of breath, among others).

In our study we followed the multidimensional approach, covering all the above mentioned relevant domains of quality of life.

\section{Materials and Methods}

The quality of life study was initiated to assess differences in quality of life of patients with fecal incontinence before and after dynamic graciloplasty in a prospective longitudinal way. A group of 30 patients entered the quality of life study. The thirty patients were 21 female and 9 male with a median age of 47 years (range 22-71 years). They suffered from incontinence for a median time of 8 years (range 0.36 years). Measurements were performed 2 months preoperatively, and 8 , 26 and 52 weeks post-operatively. The preoperative measurement was used as the control measurement.

\section{Quality of life instruments}

There are a number of approaches to determine the quality of life (table 1$)^{25}$ Choosing the appropriate approach to the use of a quality of life measure depends on the availability, reproducibility, validity and responsiveness (sensitivity) of the quality of life instruments. In most of the available "proven" instruments reproducibility and validity is established. Responsiveness however, appears to vary between studies. ${ }^{25}$ 
Table 1 Taxonomy of measures of health related quality of life in clinical trials

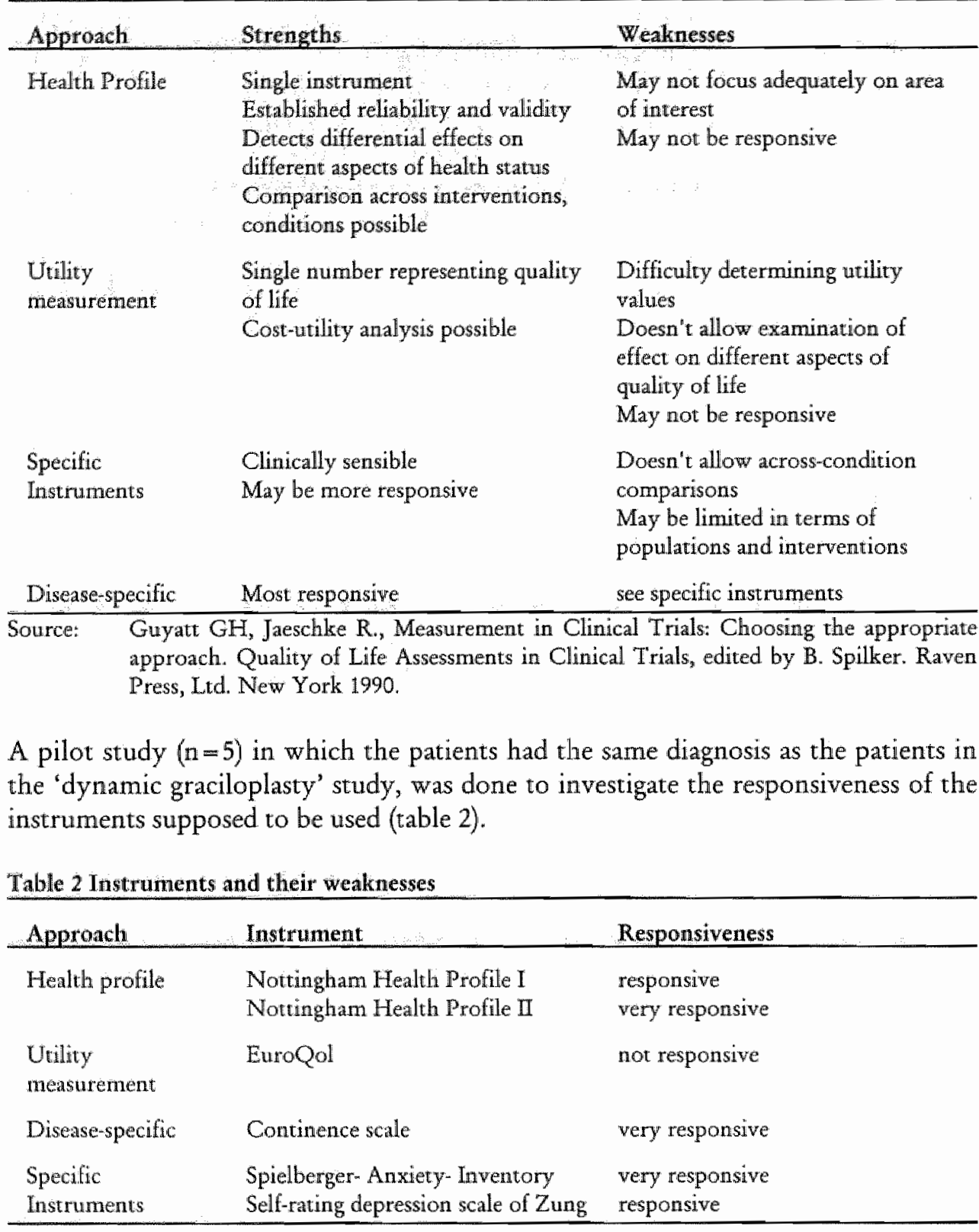

The pilot study concluded the unresponsiveness of the EuroQol instrument with regard to fecal incontinence, and on that basis, the test was not included in the final study. 
The following questionnaires with regard to quality of life aspects were administered in the present study:

- The Nottingham Health Profile part $1\left(\mathrm{NHP}^{2}\right)^{26,27}$, which is designed as a comprehensive instrument to measure perceived health on 6 specific domains of life (mobility, pain, energy, sleep, social isolation, emotional reaction). "The NHP-1 ranges from $O$ (no health problems) to 100 (many health problems).

- Part 2 of the Nottingham Health Profile (NHP-2) ${ }^{25,27}$, which relates to those areas of "task performance" most affected by health. It consists of seven statements which refer to the effects of health problems on : occupation, ability to perform tasks around the home, personal relationships, sex life, social life, hobbies and holidays. The score ranges from 7 (no problems) to 21 (many problems).

- The State Trait Anxiety Inventory (STAI) ${ }^{28,29}$, which measures specifically anxiety. The scores on the questionnaire can be interpreted as follows: $<38$ : not anxious; $38<$ moderately anxious $<47,>47$ : very anxious.

- The Self-rating Depression scale of Zung (Zung) ${ }^{30,31}$, which measures specifically depression. The scores on the questionnaire can be interpreted as follows: $<35$ : not depressed; $35<$ moderately depressed $<50,>50$ : very depressed (psychiatric care needed).

All these questionnaires had previously been validated and translated into the Dutch language. $27,28,10$

- The disease specific questionnaire used in the present study was based on the continence scale as described by Williams. ${ }^{17}$ Score I is continent to solids, liquids and flatus, score II is continent to solids and liquids but not to flatus, score III continence to solids but occasional episodes of liquid incontinence, score IV is frequent episodes of incontinence of liquids and $\mathrm{V}$ is frequent episodes of incontinence of solids and liquids. To our criteria only score I and II are continent and are scored as a successful procedure.

The results of all questionnaires involved in the study were stratified for "success" of the operation.

In addition, patients were stratified according to whether their incontinence had lasted a long or a short time in relation to their age, in order to investigate a potential relation of this variable with adaptation to their condition. Duration was considered to be long if years of incontinence divided by years of age equalled 0.9 or more. The groups, thus defined, were compared on the basis of the preoperative scores on part 2 of the Nottingham Health Protile. Lower scores on the NHP-2 indicated better adaptation. 


\section{Statistics}

Statistical analysis was performed non-parametrically using the Mann-Whitney U Test (unpaired data) for testing the difference in adaptation between the short and long duration group, and the Wilcoxon-signed-rank test (paired data) to compare quality of life pre- versus postoperative. In general data were expressed as median and (interquartile) range. With regard to table 3 data were expressed as median and interquartile ranges of the differences between preoperative and postoperative measurements. A P value of 0.05 or less was considered to indicate statistical significance.

\section{Results}

The results of the 'quality of life' evaluation comprised of a group of 30 patients and are shown in table 3 . Treatment was successful in 22 patients and unsuccessful in 8 patients. Demographically both groups were equal. The education levels were equally divided among both groups. There was good correlation $(r=0.76, n=30$, $\mathrm{p}<0.001)$ between the clinical results as scored by the physicians ${ }^{17}$ and the results obtained by the independent quality-of-life researcher who scored the questionnaires the patients completed at home.

The State-Trait Anxiety Inventory (STAI) questionnaire showed that successfully treated patients were less anxious than before the operation $(P=0.002)$ (table 3 , figure 2). 


\section{State-Trait Anxiety Inventory}

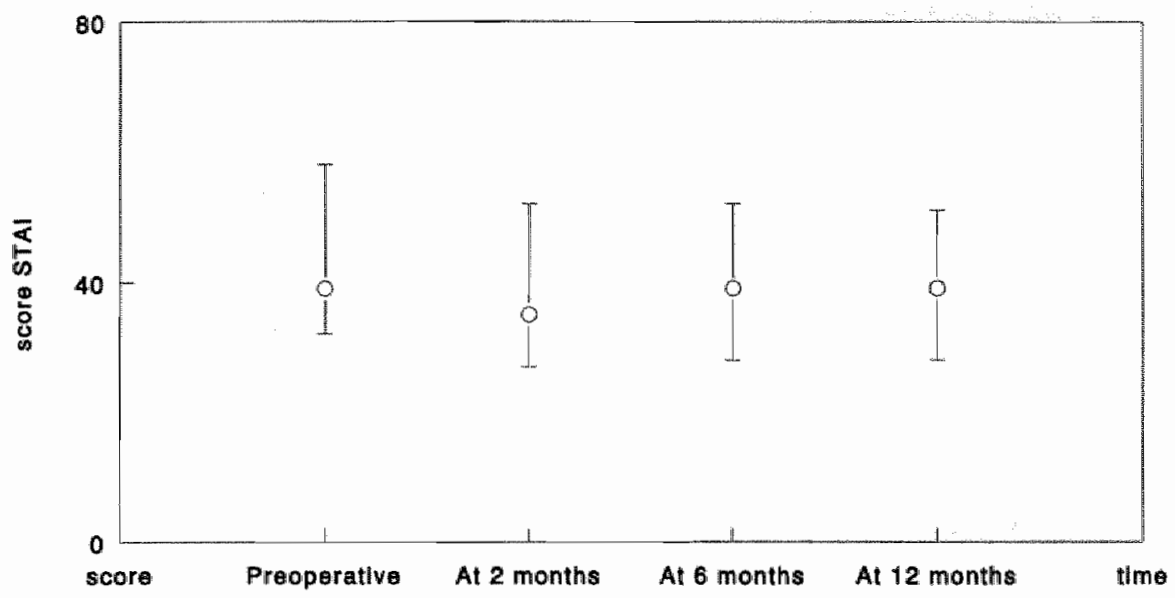

Figure 2 Prospective course of anxiety after Dynamic Graciloplasty

Data presented as median and interquartile range; Outcome interpretation

20-38 not anxious

$39-46$ moderately anxious

47-80 extremely anxious

Vertical Axes: level of anxiety

Horizontal Axes: Measurement period/Follow-up 


\section{Nottingham Health Profile -II}

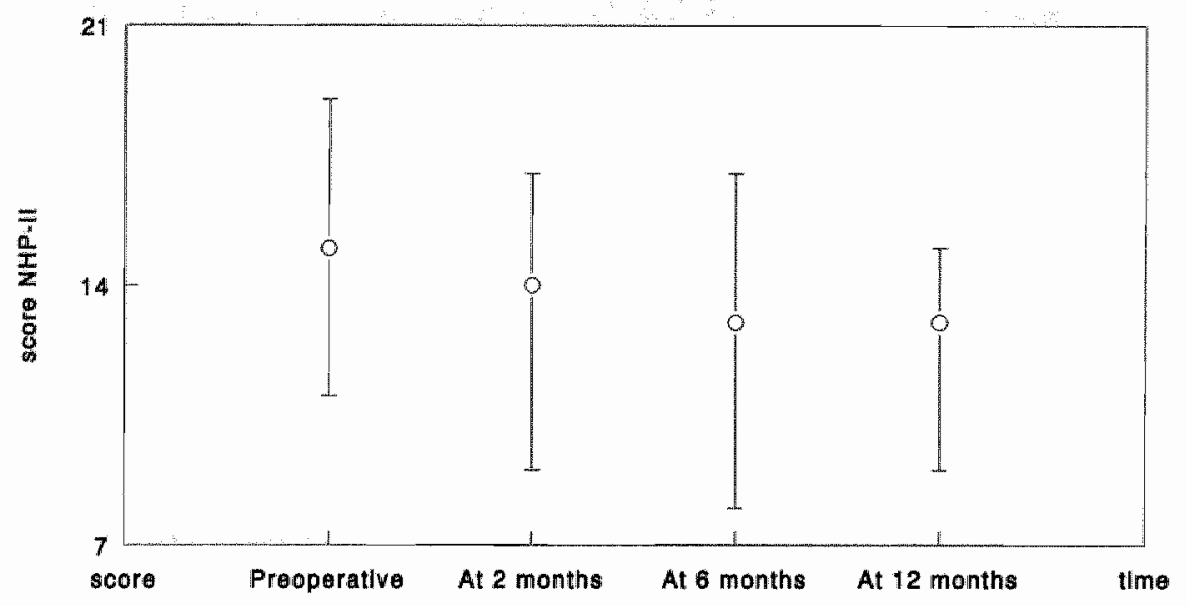

Figure 3 Prospective course of performance on daily activities after successful Dynamic Graciloplasty

Data presented as median and interquartile range. Outcome range 7-21. The lower the score the less problems with performance in daily life.

Vertical Axes: Score on NHP-II

Horizontal Axes: Measurement period/Follow-up 
Part 2 of the Nottingham Health Profile questionnaire revealed significant improvement in the successfully treated group at 8,26 , and 52 weeks $(P=0.01)$ (table 3 , figure 3).

These patients also had significant improvement at 26 weeks $(\mathrm{P}=0.05)$ (table 3 ) with regard to social isolation, a dimension analysed in part I of the Nottingham Health Profile that is of particular importance in this population.

No significant changes were found in either group in the results of the Self-rating depression questionnaire of Zung (figure 4).

\section{Self-rating Depression scale}

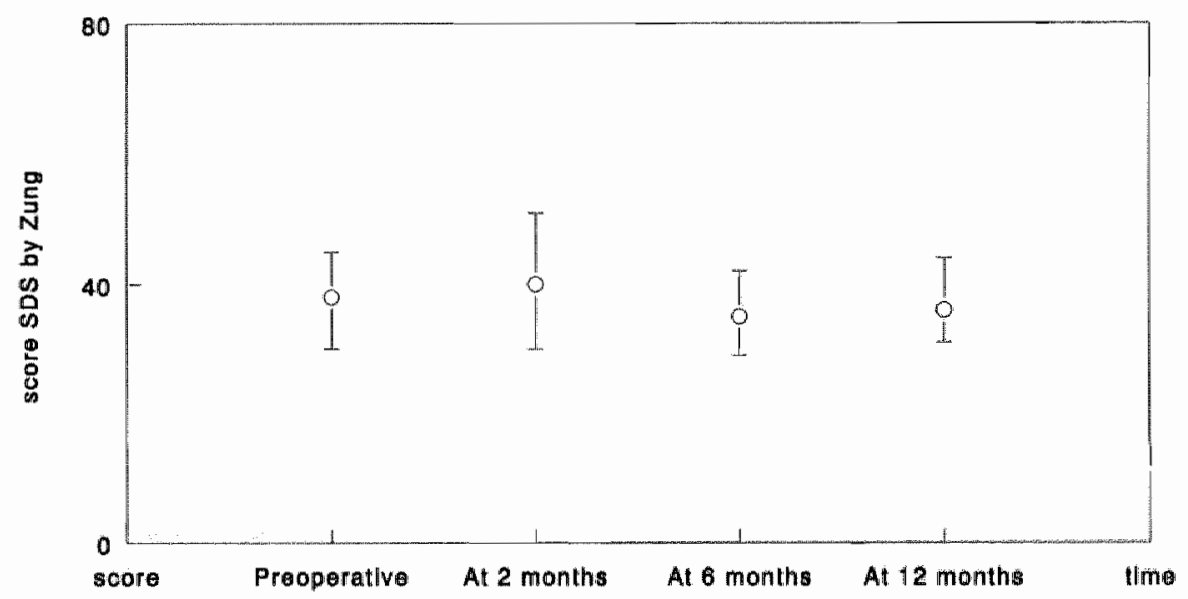

Figure 4 Prospective course of depression after Dynamic Graciloplasty

Data presented as median and interquartille range; Outcome interpretation

20-35 not depressed

$36-50$ moderately depressed

$>50$ seriously depressed

Vertical Axes: level of depression

Horizontal Axes: Measurement period/Follow-up 
There were no significant changes in any area of any questionnaire in the unsuccessfully treated group, compared to pre-surgery testing, meaning no deterioration after surgery (table 3).

Significant differences were found between the patients with a short duration of incontinence and those with a long duration (i.e, patients with congenital anal atresia). Patients with anal atresia scored very well preoperatively on all questionnaires (with scores similar to those of healthy persons), unlike those patients who had a short history of incontinence. 
Table 3 Results of the Quality-of-Life evaluation in 30 patients who underwent anal dynarmic graciloplasty

Assessment Instrument
and group of patients

Difference from preoperative score

At 2 months At 6 months

At 12 months

\begin{tabular}{|c|c|c|c|}
\hline \multicolumn{4}{|c|}{ State-Trait Anxiety Inventory } \\
\hline Trearment successful & $-4(-12$ to 6$)$ & $-6(-10$ to 1$)$ & $-6(-8$ to 1$)$ \\
\hline Treatment unsuccessful & $-5(-9$ to -1$)$ & $-1(-5$ to 3$)$ & $5(7+08)$ \\
\hline \multicolumn{4}{|l|}{ Zung Scale } \\
\hline Treatment successful & $-1(-6 \operatorname{to} 7)$ & $-1(-6$ to 2$)$ & $-2(-4$ to 3$)$ \\
\hline Treatment unsuccessful & $1(-6$ to 7$)$ & $2(-7$ to 1$)$ & $7(-3$ to 9$)$ \\
\hline \multicolumn{4}{|c|}{ Nottingham Health Profile, part I } \\
\hline \multicolumn{4}{|c|}{ Treatment successful } \\
\hline Mobility & $0(-9$ to 0$)$ & $0(-11$ to 0$) \mathbb{1}$ & $0(-12$ to 5$)$ \\
\hline Pain & $0(0$ to 26$)$ & $O(-1$ to 21$)$ & $0(-11$ to 21$)$ \\
\hline Energy & $0(0$ to 0$)$ & $O(0$ to 0$)$ & $0(0$ to 19$)$ \\
\hline Sleep & $0(0$ to 13$)$ & $\mathrm{O}(\mathrm{O}$ to 2$)$ & $0(-4$ to 6$)$ \\
\hline Sacial isolation & $0(0$ to 0$)$ & $O(-23$ to 0$) Y$ & $O(-21$ to 0$)$ \\
\hline Emotional reaction & $O(-14$ to 12$)$ & $0(-10$ to 0$)$ & $0(-21$ to 1$)$ \\
\hline \multicolumn{4}{|l|}{ Treatment unsuccessful } \\
\hline Mobility & $0(-17$ to 0$)$ & or(o to 11$)$ & $0(-27$ to 31$)$ \\
\hline Pain & $O(-10$ to 0$)$ & $-2(-8$ to 0$)$ & $0(-12+07)$ \\
\hline Energy & $O(0$ to 2$)$ & $O(-28$ to 0$)$ & $0(-13$ to 24$)$ \\
\hline Sleep & $O(-22$ to 0$)$ & $O(17$ to 0$)$ & $0(0$ to 17$)$ \\
\hline Social isolation & $O(-19$ to 19$)$ & $a(-12$ to 0$)$ & $0(-43$ to 22$)$ \\
\hline Emotional reaction & $1(-9$ to 7$)$ & $-6(-16$ to 0$)$ & $0(-6$ to 9$)$ \\
\hline \multicolumn{4}{|c|}{ Nottingham Health Profile, part 2} \\
\hline Treatment successful & $-2(-3$ to 0$) t$ & $-1(-4$ to 0$)$ & $-2(-6 \text { to }-1)^{2+2+45}$ \\
\hline Treatment unsuccessful & $1(0$ to 3$)$ & $2(-7$ to 1$)$ & $-1(-3$ to 4$)$ \\
\hline
\end{tabular}

Results of the Quality of-Life evaluation in 30 patients who underwent anal dynamic graciloplasty, according to whether their treatment was successful or unsuccessful. Negative walues indicate improvement, positive values deterioration, and 0 means no change compared to their pre-operative state. Treatment was successful in 22 patients and unsuccessful in

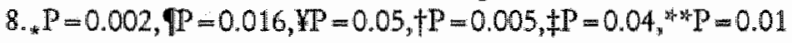

\section{Discussion}

Since 1952 conventional graciloplasty has been performed to replace a dysfunctional or absent external anal sphincter, and contradictory results have been reported. ${ }^{9,10,22,13,32,33}$ The basic problem has been that the patient cannot achieve sustained contraction of the transposed muscle. This problem can be solved by stimulating the gracilis muscle electrically with implanted electrodes. ${ }^{20,21}$ 
The patients in whom this technique was successful (continence improved) became less anxious and improved in areas such as effectiveness in their occupation, ability to do tasks around the home, personal relationships, sexual function and social life. Furthermore, the patients became less socially isolated, when measured 52 weeks after treatmient.

Patients in whom the operation failed remained at their preoperative level with regard to all aspects of quality of life.

In neither successful nor unsuccessful patients significant negative effect was found on the dimension mobility, including early postoperative deterioration, suggesting that gracilis muscle transposition does not interfere with the patient's mobility.

Patients with longstanding incontinence (i.e., those with congenital anal atresia) scored very well preoperatively on all questionnaires. This finding of good preoperative scores in patients with longstanding fecal incontinence had consequences for the results. These preoperative scores implicate that in this group only a marginal increase could be achieved. The latter underlines the need for good sensitivity of the underlying questionnaires (responsiveness). ${ }^{17,26,27,28,29,30,31}$ Such questionnaires should be sensitive enough to register and reflect all changes in quality of life after surgery. It should be questioned whether the questionnaires that were used reflect all quality of life aspects of the patients in our study. In addition, one might question on which grounds these well adapted patients with such good preoperative scores should be submitted to extensive, expensive surgery at all. It might be that the questionnaires used did not cover all aspects of quality of life because these patients not only agreed with surgery, they specifically asked for dynamic graciloplasty, despite having such good preoperative scores. Also, it is reported by Rintala et al, that adaptation to lifelong incontinence in patients with operated low anorectal malformations (anal atresia) cannot be expressed as "generally good".'

Besides dynamic graciloplasty or accepting incontinence and managing it with the help of diapers or enemas', a third option is available, the creation of a colostomy. Studies comparing dynamic graciloplasty with the alternative, creating a colostoma, are not yet performed. On the other hand several studies comparing quality of life of ostomates with non-ostomates conclude that having a stoma decreases quality of life in general. More specifically, quality of life of ostomates versus non-ostomates with the same medical history is worse in several dimensions (Depression, Psychological disturbance ${ }^{34}$, Loneliness ${ }^{34}$, Suicidal thoughts ${ }^{34}$, Feelings of stigma ${ }^{7}$, Low self esteem ${ }^{7}$, Change in body image ${ }^{8}$, Feeling of unpleasant odor ${ }^{6}$ ). Stoma parients report higher levels of psychological distress than nonstoma patients and 
problems related to social functioning are more prevalent among patients with a colostomy. The patients in these studies all had an oncological past, which made them significantly different from the patients in our study. More important in drawing conclusions about differences in quality of life between dynamic graciloplasty and having a colostomy is the fact that having normal continence after removal of a high rectal tumour is something different than continence after dynamic graciloplasty. Further research in this field needs to be undertaken.

\section{Conclusion}

The present study showed that the treatment of dynamic graciloplasty improved quality of life in a number of significant domains, if continence could be achieved. Failure of the technique did not affect quality of life significantly. Furthermore, patients with longstanding incontinence were better adapted to their 'imperfect' health status than patients who had been incontinent for a shorter time.

\section{References}

1 Rintala $\mathrm{R}$, Mildh $\mathrm{L}$, Lindahl $\mathrm{H}$. Fecal continence and quality of life in adult patients with an operated low anorectal malformation. J Pediatr Surg 1992;27:902-5.

2 Mandelstam DA. Incontinence, social and economic factors. In coloproctology and the pelvic floor. Henry MM and Swash M (eds) 1985:217-22.

3 Thomas TM, Egan M, Walgrove A, Meade TW. The prevalence of faecal and double incontinence. Community Med 1984;6:216-220.

4 Nelson R, Norton N, Cautley E. Prevalence of fecal incontinence in Wisconsin households. Dis Colon Rectum 1994;37:Suppl:P9. abstract.

5 Madoff RD, Williams JG, Caushaj PF. Fecal incontinence. N Engl J Med 1992;9:1002-7.

6 Frigell A, Ottander M, Stenbeck $\mathrm{H}$ and Pahlman L. Quality of life of patients treated with abdominoperineal resection or anterior resection for rectal carcinoma. Ann. Chir. gynaecol. 1990;79:26-30.

7 Sprangers MAG, Taal BG, Aaronson NK, te Velde A. Quality of life in colorectal cancer: stoma ws. nonstoma patients. Dis colon Rectum 1995;38:361-36\%

8 Williams NS, Johnston D. (1983) The quality of life after rectal excision for low rectal cancer. B J Surg. 1983;71:460-462.

9 Pickrell KL, Broadbent TRR, Masters FW, Metzger JT. Construction of a rectal sphincter and restoration of anal incontinence by transplanting the gracilis muscle: report of four cases in children. Ann Surg 1952;135:853-62.

10 Yoshioka K, Keighly MRB. Clinical and manometric assessment of gracilis muscle transplant for fecal incontinence. Dis Colon Rectum 1988;31:767-9. 
11 Konsten ], Baeten CGMI, Havenith MG, Soeters PB. Morphology of dynamic graciloplasty compared with the anal sphirncter. Dis Colon Rectum 1993;36:559-63.

12 Leguir $P$, Baal van $J G$, Brummelkamp WH. Gracilis muscle transposition for fecal continence. Long term follow -up and ewaluation of anal pressure recordings. Dis Colon Rectum 1985;28:1-4.

13 Raffensperger J. The gracilis sling for fecal incontinence. J Pediatr Surg 1979;6:794-7.

14 Bactea C, Spaans F, Fluks A. An implanted neuromuscular stimulator for fecal incontinence following previously implanted gracilis muscle. Dis Colon Rectum 1988;31:134-7.

$15 \mathbb{M a l l a n}$ RI, Williams NS, Futton MRE, et. al. Electrically stimullated sartorius neosphincter: canine model of activation and skeletal muscle transformation. $\mathrm{Br} J$ Surg 1990;77:208-13.

16 Baeten CGMI, Konsten J, Spaans F et al. Dynamic graciloplasty for treatment of faecal incontinence. Lancet 1991;338:1163-5.

17 Williams NS, Patel J, George BD, Hallan RI, Watkins ES. Development of an electrically stimulated neoanal sphincter. Lancet 1991;338:1166-9.

18 Salmons $S$, Vibova $G$. The influence of activity on some contractile characteristics of mammalian fast and slow muscle. J Physiol (Lond) 1969;201:535

19 Chacques JC, Grandjean PA, Carpentier A. Dynamic Cardiomyoplasty: experimental cardiac wall replacement with a stimulated skeletal muscle. In: Cardiomyoplasty and muscle-powered devices. RCJ Chiu,editor. New York: Futura Publishing;1986:59-84.

20 Konsten J, Baeten CGMI, Spaans F, Havenith MG, Soeters PB. Follow up of anal dynamic graciloplasty for fecal incontinence. World J Surg 1993;17:404-9.

21. George BD, Williams NS, Patel J, Swash M, Watkins ES. Physiological and histochemical adaptation of the electrically stimulated gracilis muscle to neoanal sphincter function. Br J Surg 1993;80:1342-6.

22 Konsten J, Baeten CGMI, Spaans F, Havenith MG, Soeters PB. De dynamische gracilisplastiek, een nieuwe chirurgische techniek voor de behandeling van faecale incontinentie. Ned Tijdschr Geneesk 1992;136:2178-2:182.

23 Bonsel GJ. Quality of life measurement and medical technology assessment, Nederlands Tijdschrift voor de Psychologie 1991;46:180-186.

24 Schipper H, Clinch J, Powell V. Definitions and Conceptual Issues. In: Quality of Life Assessments in Clinical Trials, edited by B. Spillker. Raven Press, Lrd. New York 1990.

25 Guyatt $\mathrm{GH}$, Jaeschke R., Measurement in Clinical Trials: Choosing the appropriate approach. Quality of Life Assessments in Clinical Trials, edited by B. Spilker. Raven Press, Ltd. New York 1990.

26 Hunt SM, McEwen J, McKenna SP. Measuring Health Status: A new tool for clinicians and epidemiologists. Journal of Royal College of General Practitioners 1985;35:185-188.

27 Stouthart MEA, Bonsel GJ. Nederlandse bewerking NHP-DA, 1991.

$28 \mathbb{P l o e g}$ HM van der, Defares PB, Spielberger CD. Een Nederllandstalige bewerking van de Spielberger State-Trait Anxiety Inventory: de Zelfbeoordelings Vragenlijst. De Psycholoog $19: 80 ; 15: 460-467$

29 Spielberger CD, Gorsuch RL, Lushene RE (eds). STAI manual for the state-trait anxiety inventory. Consulting Psychologists Press. Inc. Palo Alto, California 1970.

30 Dijkstra P. The self-rating depression scalle of Zung (in Dutch), In: Prag HM van, Rooymans HGM (eds) Stemuning en ontstemming. De Erven Bohn BV, Amsterdlam 1980:56-67. 
31. Zung WhW.A self-rating depression scale. Arch Gen Psychiatry 1965;13:63-70,

32 Corman MI. Follow up evaluation of gracilis muscle transposition for fecal incontinence. $D$ is Colon Rectum 1980;8:552 -5.

33 Sonnino RE, Reinberg O, Bensoussan AL, Laberge JM, Blanchard H. Gracilis muscle transposition for anal incontinence in children; long-term follow up. J Pediatr Surg 1991;10:1219-23.

34 Wirsching M, Druner HU, Herrmann G. Results of psychosocial adjustment to long term colostomy. Psychother Psychosom 1975;26:245-256. 


\section{Cost-effectiveness of dynamic graciloplasty in patients with fecal incontinence}

This chapter was submitted under the title:

Cost-effectiveness of dynamic graciloplasty in patients with fecal incontinence. Adang EMM, Engel GL, Rutten FFH, Geerdes B, Baeten CGMI. (In press Dis Colon Rectum ) 


\section{Summary}

The purpose of this chapter is to evaluate the cost-effectiveness of Dynamic Graciloplasty for intractable fecal incontinence.

Costs and effects of Dynamic Graciloplasty were measured in a prospective longitudinal study along-side a clinical trial. Forty three patients with intractable fecal incontinence were evaluated before and after Dynamic Graciloplasty. Costs were obtained from the hospital information system and through patient oriented questionnaires. A comparison was made with the costs of a Colostomy. This was evaluated in a group of 7 patients who had a stoma for incontinence for several years.

Total direct costs of life long Dynamic Graciloplasty were 31733,- US Dollars, of life long conventional treatment US $\$ 12180$,- and of Colostomy including life long stoma care US $\$ 71576$,-. The clinical success rate of Dynamic Graciloplasty was $74 \%$. Quality of life after successful Dynamic Graciloplasty was better than for conventional treatment.

Dynamic Graciloplasty was found more expensive than conventional treatment but resulted in a significantly better quality of life. The stoma alternative was least attractive regarding both costs and effects. It was recommended by the Dutch Health Insurance Executive Board to reimburse the Dynamic Graciloplasty procedure.

\section{Introduction}

Medical Technology Assessment (MTA) is becoming a valuable tool to assist policymakers in controlling new medical technologies. ${ }^{1}$ The Dutch government funds projects to evaluate new or established medical technologies, looking prospectively at efficacy, cost-effectiveness, social, ethical and legal implications, in view of the policy decisions to be taken. In 1991 the underlaying project, 'Dynamic Graciloplasty: neurostimulation of a transposed skeletal muscle, a new therapy for fecal incontinence', was started. The present study dealt with the cost-effectiveness analysis of this new treatment for intractable fecal incontinence.

\section{Prevalence of fecal incontinence and treatment modalities}

Intractable fecal incontinence is commonly related with social and sexual problems. ${ }^{2}$ Data from Great Britain report a community prevalence of 4.2 men and 1.7 women per 1000 people who are 15 to 64 years of age, and of 10.9 men and 13.3 women per 
1000 people who are 65 or older. ${ }^{3}$ More recent figures from the US report an overall prevalence of 2.3 percent. Incontinence can be treated in various ways such as medical therapy, biofeedback training and change of diet. ${ }^{5}$ If not successful, surgical therapy may follow. When accepted surgical interventions like anal repair or post anal repair are not successful, patients have three options:

- A new surgical intervention, Dynamic Graciloplasty (DGP), which creates a new sphincter with a neurostimulated graciloplasty. ${ }^{6}$

- To accept their incontinence and help themselves with diapers or try to obtain pseudo continence with enemas. In our study this option was referred to as conventional treatment.

- The third option is to create a colostomy and change anal incontinence into a manageable incontinence at the abdominal site.

\section{Patients and methods}

\section{Patients}

A group of 43 consecutive patients, suffering from fecal incontinence, entered the prospective evaluation study. The patients in this study have had several previous operations without any success before they underwent DGP. The 43 patients were 32 female and 11 male with a median age of 48 (range 22-74) years. They suffered from incontinence for a median time of 8 years (interquartile range 3-20 years). The present situation of these patients was the resultant of conservative treatment. All. patients had frequent episodes of incontinence of solid and liquid stools. Characteristics of these patients with severe fecal incontinence before DGP were described previously. ${ }^{6}$ Perineal trauma was the most frequently reported cause of the initial fecal incontinence. This group of patients underwent a DGP procedure and the end stage of this procedure was considered the result of the DGP procedure. To define success or failure of the DGP procedure a continence scale ${ }^{6}$ was used.

A randomized controlled trial, including the three alternatives, was seen as ethically impossible. For the colostomy alternative 7 patients, who received a colostomy because of severe incontinence, were found in the data base of the stomanurse at our hospital. The stoma group was considered to small for a QoL comparison with the DGP group. Therefore QoL evaluation of ostomates versus non-ostomates was based on literature study. The cost data of the 7 patients were used to calculate the costs of a colostomy and the costs of stoma-care. The stoma group (mean age 47 years) consisted of 5 female and 2 male. The most frequently reported cause of the initial fecal incontinence of these patients was perineal trauma, which was also the case in the DGP group. None of the ostomates had a cancer history. 
Quality of Life Analysis

Effects of DGP were measured as changes in Quality of Life (QoL), defining QoL functionally by the patients' perception of performance in four areas: physical and occupational function, mental state, social interaction, and somatic sensation.? Methods, used in the present study, have already been published together with the clinical data for a group of 30 patients. ${ }^{6}$ For the present study 13 consecutive patients were added.

QoL was measured in four questionnaires: the Nottingham Health Profile, part 1 (NHP-1) and part 2 (NHP-2), Self-rating Depression scale of Zung. ${ }^{12,13}$

\section{Cost Analysis}

The costs of all activities were calculated: in and outside the hospital, and, of all three alternatives. Costs were based on real prices, not on charges. A distinction was made between direct and indirect costs (e.g., productivity losses).

Because fecal incontinence is a chronic disease all study alternatives were considered in a life long setting. All costs were discounted to present values at a $5 \%$ rate. An average lifetime expectancy of the population of 30 years was based on the average age of the population ( 45 years).

The entire cost analysis was done from a societal perspective; meaning all costs were included in the analysis, irrespective of who beared the costs, the patient, private health insurance, or the national health insurance.

\section{Dynamic Graciloplasty}

The DGP cost-analysis was based on intention to treat, including the cost for a successful and unsuccessful procedure. After an unsuccessful procedure patients had three options; They could choose for a new DGP procedure in which the neurostimulator and leads from the initial procedure could be re-used, another possible option was to undergo a colostomy, and finally they could decide to maintain in their present situation which results in conventional treatment (figure 1). 


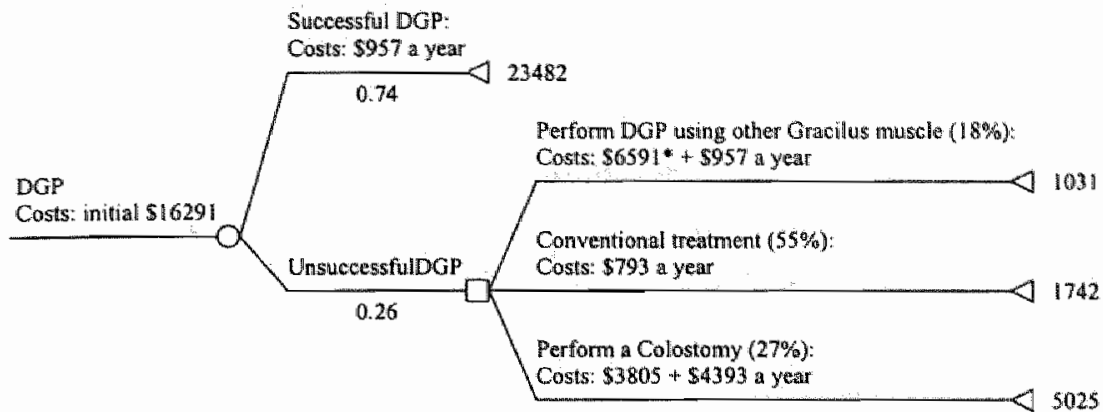

Figure 1 Decision model Dynamic Graciloplasty

Cost-analysis Dynamic Graciloplasty, an intention to treat approach

o chance node: Represents an uncertain situation which results in a true state, successful or unsuccessful

$\square$ decision mode: It signifies a decision to be made among the alternative branches emanating from it.

$\checkmark$ terminal node: Indicates that the path's end is reached.

Numbers are in US Dollars

${ }^{*}$ Neurastimulator and leads excluded.

To calculate the direct costs inside the hospital all medical performances per patient related to the DGP procedure were counted: the operation, an outpatient visit and the days occupying a hospital bed. Also the pre and postoperative investigations, for example, manometry, defecography and electromyography were included.

In the operation health professionals' time, surgeon, resident, anaesthesiologist, and nursing staff time are included. Also supplies, medication, equipment, costs of housing, feeding, administration and management, were included. The analysis included costs of medical complications and failures as well. The longevity of the neurostimulator is limited. Considering a lifelong treatment, the neurostimulator needs to be replaced several times. "The direct costs of replacement of the neurostimulator were included.

Direct costs outside the hospital were based on questionnaires concerning the patients" expenditure due to treatment (e.g., patients" travel costs).

Indirect costs of treatment were defined as:' The value of potentially lost/gained production from present age until the age of retirement (assumed:65 years).' "The incremental value of indirect costs was determined by interviewing patients about their productivity status, before and 52 weeks after the operation. This status, 
before or after the operation, was regarded as being stable, and extrapolated to the age of retirement using an individual human capital approach. ${ }^{14}$ Finally total productivity in the conventional alternative (before operation) was subtracted from the productivity generated after DGP, precisely 52 weeks after the operation. This approach was corrected for survival rate probabilities of the general population, used by insurance companies. ${ }^{14}$ Specifically, the population was divided into five categories: housekeeping and unpaid labour, payed labour, sick leave, school, and being retired. Productivity was calculated by multiplying 1 Full Time Equivalent (1 FTE $=1640$ hours, according to Dutch standards) by the price per hour of paid labour (US \$ 14.63). Housekeeping and performing unpaid labour were valued at $2 / 3$ of paid labour. The other categories generated 0 productivity. The objective of the indirect cost analysis was to determine whether undergoing DGP resulted in a change in composition of the population with regard to the five specified categories (table 3).

\section{Conventional treatment}

There were no direct costs made inside the hospital for this treatment. For conventional therapy direct costs outside the hospital were recorded, such as diapers, enemas, tissues and diets. These costs were based on data collected from the 43 patients.

Indirect costs were calculated the same way as in DGP.

\section{Colostomy}

For the Colostomy alternative, data of seven patients with a colostomy for incontinence were used. Direct costs inside the hospital included all performance related costs like for example, operation costs and hospitalization costs. For complications (retractions, prolapse, and stenosis (10.9\%), hernia (3\%), abscess $(0.9 \%)$ ) estimates were based on literature. ${ }^{15}$ All stoma appliances, provided by national health insurance, formed the direct costs outside the hospital.

Productivity of stoma patients was assumed the same as for those patients who underwent DGP. 


\section{Sensitivity analysis}

Costs were submitted to sensitivity analyses to examine whether variations in our assumptions would seriously affect the calculations, with respect to the "discount rate", "price of the neurostimulator" and "hospital stay".

Direct costs inside the hospital were strongly related to the longevity of the neurostimulator. This longevity was dependent on the program settings of the stimulator used in DGP treatment. ${ }^{6}$ Calculations were made regarding the replacement of the stimulator, varying longevity from 2 to 9 years.

Only few patients in our data-base (5) had a DGP longer than 8 years (longterm). The failure rate in this group was 0 . Based on these few patients a robust conclusion with regard to failure of the DGP procedure on the long-term cannot be given. Therefore this aspect was included in the sensitivity analysis. The probability of failure of the DGP procedure on the long-term was estimated, and evaluated at $2 \%$.

\section{Statistics}

Prices and volumes of performances were calculated as average values. Statistical analysis for QoL data was performed non-parametrically using the Wilcoxonmatched-pairs signed-rank Test to compare QoL pre- versus postoperative. ${ }^{6}$ QoL data were expressed as median and (interquartile) range of the differences between preoperative score and postoperative score.

\section{Results}

\section{Quality of Life}

The entire DGP group increased pre versus postoperative significantly on the STAI $(p=0.02$ at $T=12$ months), the NHP-II $(p=0.009$ at $T=6$ months, and $p=0.036$ at $\mathrm{T}=12$ months), and on the dimension social isolation of the NHP-I $(p=0.011$ at $\mathrm{T}=6$ months).

The success rate of the operation was $74 \%$. The STAI questionnaire showed that the successful DGP group, measured 26 and 52 weeks postoperatively, became less anxious $(p=0.0016)$. Pre versus postoperative no significance was found on the Self Rating Depression scale of Zung in the successful group nor in the unsuccessful group. The NHP-2 questionnaire showed a significant improvement on task performance in the successful group $(p=0.0003), 26$ and 52 weeks after the operation, compared to Conventional treatment (preoperative). The NHP-1 showed a significant improvement on the dimension social isolation $(p=0.048)$ in the successful group after the operation (table 1). For the unsuccessful group no significant change was noticed, meaning no deterioration after surgery. 
Table 1 Quality of Life results of patients who had a successful Dynamic Graciloplasty compared to conventilional treatment.

\begin{tabular}{|c|c|c|c|c|}
\hline & $\begin{array}{l}\text { Preoperative/ } \\
\text { Conwentional }\end{array}$ & $\begin{array}{c}6 \text { months } \\
\text { post }\end{array}$ & $\begin{array}{l}12 \text { months } \\
\text { post }\end{array}$ & significance \\
\hline$S T A I$ & 47 & $-5(-11,1)^{2}$ & 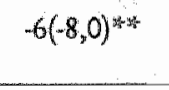 & $\begin{array}{l}p=0,0096 \\
* p=0,0016\end{array}$ \\
\hline Zung & 39 & $-1(-7,2)$ & $-2(-5,4)$ & \\
\hline \multicolumn{5}{|l|}{$\mathrm{NHP}-1$} \\
\hline mobility & 21 & $O(0,11)$ & $O(-11,12)$ & \\
\hline pain & 0 & $O(-5,25)$ & $3(0,34)$ & \\
\hline energy & 61 & $O(0,0)$ & $0(0,0)$ & \\
\hline sleep & 0 & $O(-3,0)$ & $0(-9,0)$ & \\
\hline social isolation & 0 & $0(-20,0)=$ & $0(-20,0)$ & $\mathrm{p}=0,048$ \\
\hline emotional reaction & 7 & $0(-10,0)$ & $0(-20,2)$ & \\
\hline $\mathrm{NHP}-2$ & 15 & $-2(-4,0))^{* 5}$ & 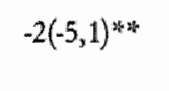 & $\begin{array}{l}* p=0,0030 \\
* *=0,0003\end{array}$ \\
\hline
\end{tabular}

Data presented as median (pre-operative value), and median and interquartile range of the differences between pre and post-operative score

0 :no difference in Quality of Life parameter pre- (conventional) versus postoperative (DGP)

$>0$ : deterioration in Quality of Life parameter

$<0$ improvement in Quality of Life parameter

Cost

The cost analysis showed that the initial total direct costs in the hospital were US $\$$ 16290 ,- for a successful DGP (including neurostimulator and leads $(\$ 9700,-)$ and hospital stay (10 days for transposition of the muscle and 5 days for implantation of the neurostimulator). Direct costs outside the hospital were US \$1388,-. When an expected life long situation was considered (30 years), assuming a technical lifetime of the neurostimulator of 7 years (based on the average setting of the neurostimulator at 3.2 Volt and $15 \mathrm{~Hz}$ in the present series of patients) total direct costs were US \$31733,- (figure 2, table 2). The Cost/Voltage function was a discontinuous one (figure 3 ). The jump, at 3.6 Volt, could be explained by a second circuit becoming active. The jump caused a decrease in longevity and an increase in costs of DGP of US $\$ 10799$,- (figure 3 ). 
Table 2 Outcome Cost analysis in US \$

Costs /

Treatment
Initial Costs per

Operation year

Costs (operation

related costs

excluded)
Life long Incremental costs indirect costs incremental (operation related costs included)

Conventional $\$ 793,-$

$\$ 6331_{x^{\prime \prime}}$

$$
\$ 957, \quad \$ 31733, \cdots
$$

$\$ 13221$,

Graciloplasty

Colostomy

$\$ 4393,-$

$\$ 71577,-*$

* Discounted to present values at a $5 \%$ rate

\# 7 years neurostimulator scenario, linear depreciated

Incremental productivity gain was US $\$ 6331$,- when patients from the conventional group received DGP (table 2 and 3).

Table 3 Changes in the composition of categories in the human capital model when conventionally treated patients received Dynamic Graciloplasty

\begin{tabular}{lrrr}
\hline Category/Group & Conventional & DGP & percentage change \\
\hline Unpaid Labour & $50 \%$ & $40 \%$ & $-10 \%$ \\
Paid Labour & $16.7 \%$ & $26.7 \%$ & $+10 \%$ \\
School & $6.7 \%$ & $6.7 \%$ & \\
Sick Leave & $20 \%$ & $16.7 \%$ & $-3.3 \%$ \\
Retired & $6.7 \%$ & $10 \%$ & $+3.3 \%$ \\
\hline
\end{tabular}

The direct costs of life-long Conventional therapy were US $\$ 12181$, (table 2 and 4).

Table 4 Conventional treatment appliances

\begin{tabular}{|c|c|c|c|c|}
\hline & Diapers & Enema & $\begin{array}{r}\text { Others (e.g. } \\
\text { tissues etc.) }\end{array}$ & Total \\
\hline $\begin{array}{l}\text { quantity } \\
\text { (average) }\end{array}$ & $\begin{array}{r}2,10 \\
\text { (per day) }\end{array}$ & $\begin{array}{r}0,70 \\
\text { (a week) }\end{array}$ & & \\
\hline $\begin{array}{l}\text { price } \\
\text { (average) }\end{array}$ & $\$ 0,74$ & $\$ 3,75$ & $\begin{array}{r}\$ 0,18 \\
\text { (expenditure per } \\
\text { day) }\end{array}$ & \\
\hline Total Costs & $\$ 1,61$ & $\$ 0,38$ & $\$ 0,18$ & $\begin{array}{r}\$ 2,17 \\
(\text { per day) }\end{array}$ \\
\hline
\end{tabular}

The direct hospital costs concerning the creation of a colostomy were US $\$$ $3805,-$. The total direct costs, including life-long (30 years) stoma-care, were US \$ 
71577 , (table 2 and 5). Costs outside the hospital (travel costs) for a Colostomy were US $\$ 694,-$.

Table 5 Colostoma appliances

\begin{tabular}{lrrr}
\hline & Stoma bags & $\begin{array}{r}\text { Pads, tissues, } \\
\text { paperbags }\end{array}$ & Total \\
\hline $\begin{array}{l}\text { quantity } \\
\text { (average) }\end{array}$ & $\begin{array}{r}2 \\
\text { (per day) }\end{array}$ & & \\
$\begin{array}{l}\text { price } \\
\text { (average) }\end{array}$ & $\begin{array}{r}\$, 32 \\
\text { average: Biotrol (most } \\
\text { expensive) and } \\
\text { Convatec (least } \\
\text { expensive) }\end{array}$ & $\begin{array}{r}\$ 514,29 \\
\text { (expenditure per year) }\end{array}$ & \\
\hline Total Costs & $\$ 3878,86$ & & $\$ 4393,15$ \\
& & & $\begin{array}{r}\text { (per year) } \\
\hline\end{array}$ \\
\hline
\end{tabular}

Table 2 shows the total and incremental costs of the three alternatives (when successful) in a life long perspective.

The breakeven points, the points where the direct costs were the same for the alternative 3 treatments, are shown in figure 2, which also shows the costpath of the different stimulator longevities.

The conventional treatment was the cheapest overall alternative. For the first three to five years the Colostomy therapy was cheaper than DGP. After five years, DGP became less expensive regardless the presented stimulator longevity scenario's (figure 2). Only for the two year longevity scenario (the most pessimistic one), break-even was reached at about 24 years (figure 2).

After an unsuccessful DGP procedure $18 \%$ of the patients optioned for a new DGP, $55 \%$ for conventional treatment, and $27 \%$ for a colostomy. Combining the costs of a successful procedure $(74 \%)$ with the costs of an unsuccessful procedure $(26 \%)$, results in costs on an "intention to treat" basis, which sum up to $\$ 35960$,(table 6 and figure 1). 
Table 6 Costs of procedure DGP "intention to treat"

\begin{tabular}{|c|c|c|c|c|}
\hline Procedure DGP & $\begin{array}{r}\text { Successful } \\
(74 \%)^{*}\end{array}$ & $\begin{array}{l}\text { Immediate } \\
\text { failure }(26 \%)^{2}\end{array}$ & $\begin{array}{r}\text { Long-term } \\
\text { ailure }(2 \% \text { of } \\
74 \%)^{\%}\end{array}$ & Total procedure \\
\hline DGP & $\$ 23482,-$ & $\$ 12034,-$ & $\$ 444,-$ & $\$ 35960^{-}$ \\
\hline
\end{tabular}

Costs: $\quad(0.74 *$ initial 16291$)+(0.74 * 957$ yearly for 30 years $)=\$ 23482$, - See also figure 1 .

* Costs: $\quad(0.26$ initial 16291$)+\left(0.26 \%\left(0.18^{*}(6591+957\right.\right.$ yearly for 30 years $)+0.55^{2}(793$ yearly for 30 years $)+0.27^{*}(3805+4393$ yearly for 30 years $\left.)\right)=\$ 12034$, - See also figure 1.

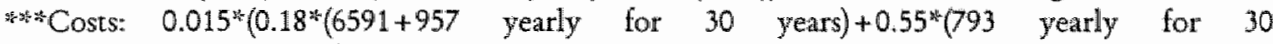
years $)+0.27^{*}(3805+4393$ yearly for 30 years $)=\$ 444,-$

Sensitivity analysis

Sensitivity analyses with regard to the costs of the DGP procedure showed relative changes of total direct costs due to changes in baseline variables.

The price of the neurostimulator, within which a change of $10 \%$ led to a change in total direct costs of $6.5 \%$.

The discount rate, a $10 \%$ change in discount-rate led to $3.9 \%$ change in total direct costs.

Hospitalization, $50 \%$ decrease in hospital stay, from an average of 14 days to an average of 7 days, could lead to a change of $5 \%$ in total direct costs.

Furthermore, was found that total costs were not sensitive for changes in patients' travel costs.

Sensitivity analysis for replacement of the neurostimulator showed that total costs varied between approximately US $\$ 74000$,- (replacement after 2 years) and US $\$ 27000$,- (replacement after 9 years).

Failure on the long-term (2\%) in the successful group (74\%) results in the same decision subtree (see figure 1) as after unsuccessful DGP. This leads to the same coststructure but for a relatively smaller part ( $2 \%$ times $74 \%$ ) and results in a costs of $\$$ $444,-$ at an uncertain time after successful DGP. 


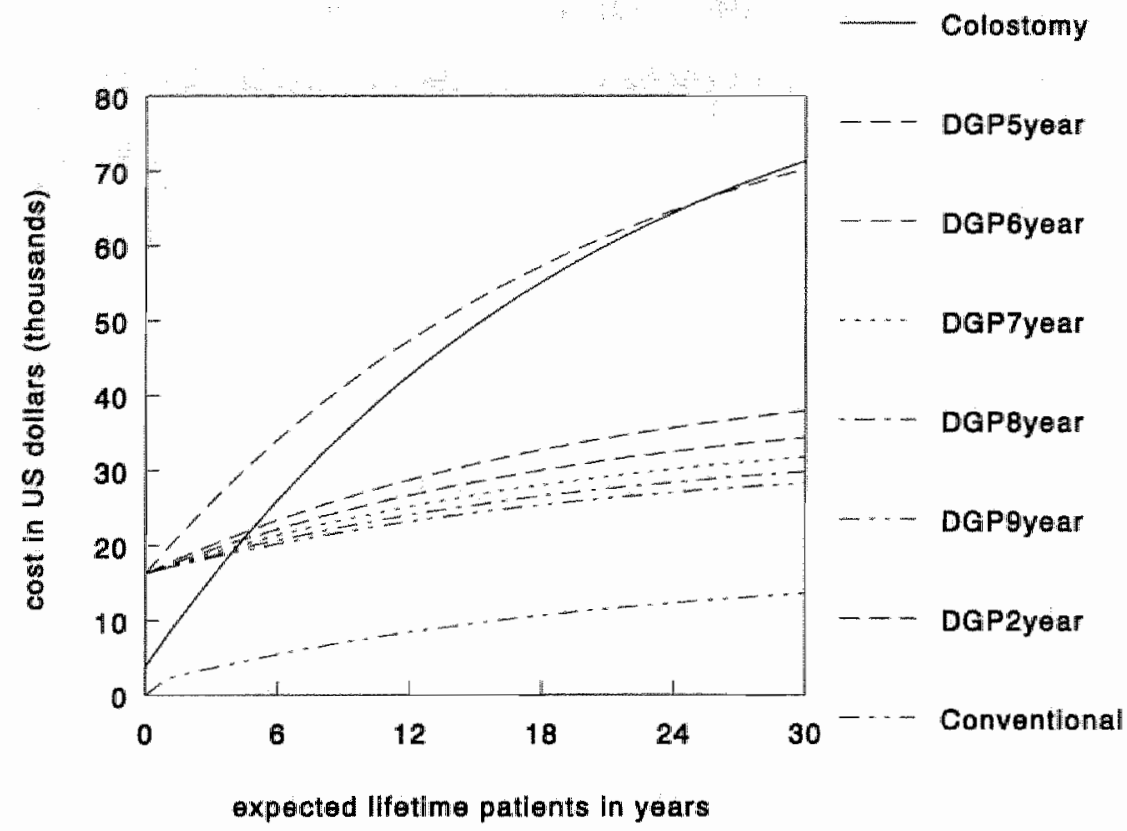

Figure 2 Cost path: DGP scenario's and alternatives 
- 15pps $\quad---25 p p s$

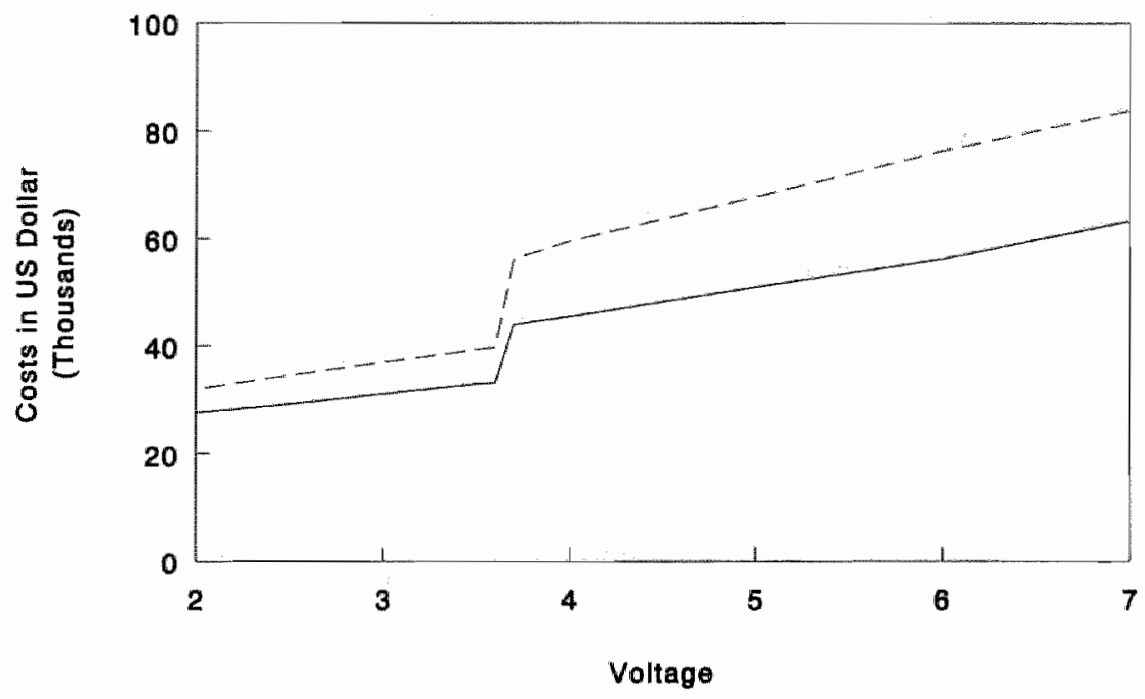

Figure 3 Cost/Voltage functions, PPS: pulses per second

\section{Discussion}

The Cost-analysis showed that the stoma alternative was the least attractive, for this particular indication, costing US $\$ 42857$,- more than DGP, without any indication that Colostomy leads to a better QoL than DGP. The cost associated with colostomy is mainly due to that of supplies. These costs could be reduced if patients for example irrigated their stoma. However, irrigation of a stoma is not always successful and adds costs of irrigation equipment. Furthermore, irrigation is a time consuming procedure and would add opportunity costs of the time consumed with irrigating one's stoma to the colostomy alternative, or could lead to productivity losses which also add costs to the colostomy alternative.

QoL of ostomates versus non-ostomates with the same medical history is worse in several dimensions (Depression ${ }^{16}$, Psychological disturbance ${ }^{17}$, Loneliness ${ }^{18}$, Suicidal thoughts ${ }^{18}$, Feelings of stigma $^{19}$, Low self esteem ${ }^{19}$, Change in body image ${ }^{16,20}$, Feeling of unpleasant odor $\left.{ }^{21}\right)$. Stoma patients report higher levels of 
psychological distress than nonstoma patients and problems related to social functioning are more prevalent among patients with a colostomy. ${ }^{22}$

QoL increased significantly in $74 \%$ of the DGP patients on several dimensions compared to conventional therapy. If DGP was not successful, QoL stayed at the pre-operative lewel. ${ }^{.}$

The costs of DGP were higher than for conventional therapy. The costs for conventional treatment were a conservative estimation, since no medical aid, no nursing assistance at home and no early admission into a nursing or elderly institution were taken into account.

On the other hand it should be remarked that at the early postoperative measurement (26 weeks) patients, treated successfully with DGP, used occasionally diapers and constipating agents, which were not included in the DGP cost analysis.

In the future it is likely that the price of the neurostimulator will drop due to economies of scale and technological innovation. Experience in the DGP procedure leads to a decrease of operation time, hospitalization, and costs. This is not completely imaginary, for instance a change of protocol from the two step (present) procedure to a one step procedure, in which the transposition and implantation of the neurostimulator is performed during the same operation, already led to this decrease. All this could result in a financially more competitive treatment compared to conventional treatment. This taken into account the ultimate valuation decision had to be made on the incremental direct cost, less than US $\$ 20000$,-, of a successful DGP that generated a significant QoL increase in $74 \%$ of the patients compared to conventional treatment. Taking Human Capital into account as well, total extra costs were less than US $\$ 15000$,- per patient treated with DGP. Costs based on intention to treat were $\$ 35960$, leading to $74 \%$ immediate success (increased QoL) and another $5 \%$ success (26\% times $18 \%$ ) after performing a second DGP (see figure 1).

\section{Policy recommendations for The Netherlands}

The Dutch Health Insurance Executive Board, which represents national health insurance in the Netherlands, gave its recommendation to the Minister of Health about Dynamic Graciloplasty. The Board stated that the investigated treatment was efficacious for the investigated indication and should be considered for reimbursement. Furthermore, the Board advised, based on aspects like quality, experience, costs, indication and patient supply, that the provision should be restricted to a limited number of specialized colorectal departments. ${ }^{23}$

a Final Report Investigational Medicine Project 91/066: Dynamic Graciloplasty: A new therapy for fecal incontinence (in Dutch), September 1994, Ziekenfondsraad 


\section{References}

1 Adang EMM, Dirksen CD, Engel GL, Baeten CGMI. Medical technology assessment: econonic evaluation of new technologies. British Journal of Hospital Medicine 1995; Vol.53,11:563-566.

2 Rintala $R$, Mildh L, Lindahl H. Fecal Continence and Quality of Life in Adult Patients With an Operated Low Anorectal Malformation. J Pediatr Surg. 1992,27:902-905.

3. Thomas TM, Egan M, Walgrove A, Meade TW. The prevalence of faecal and double incontinence. Community Med. 1984;6:216-220.

4 Nelson R, Norton N, Cautley E. Prevalence of fecal incontinence in Wisconsin households. Dis Colon Rectum 1994;37:Suppl:P9. abstract.

5 Madoff RD, Williams JG, Caushaj PF. Fecal Incontinence. N Engl J Med 1992;9:4002-1007.

6 Baeten CGMI, Geerdes BP, Adang EMM, et al.. Anal Dynamic Graciloplasty in the treatment of intractable fecal incontinence. N Engl J Med. 1995;332:1600-1605.

7 Schipper H, Clinch J, Powell V. Definitions and Conceptual Issues. In: Spilker B. Quality of Life assessments in Clinical Trials. New York, NY, Raven Press; 1990:11-24.

8 Hunt SM, McEwen J, McKenna SP. Measuring Health Status: A new tool for clinicians and epidemiologists. Journal of Royal College of General Practitioners. 1985;35:185-188.

9 Stouthart MEA, Bonsel GJ. Nederlandse bewerking NHP-DA, 1991.

10 Spielberger $\mathrm{CD}$, Gorsuch RL, Lushene RE (eds). STAI manual for the state-trait anxiety inventory. Consulting Psychologists Press Inc. Palo Alto, California, 1970.

11 Ploeg $\mathrm{HM}$ van der, Defares PB, Spielberger CD. Een Nederlandstalige bewerking van de Spielberger State-Trait Anxiety Inventory: de Zelfbeoordelings Vragenlijst.De Psycholoog $1980 ; 15 * 460-467$.

12 Zung WWK. A self-rating depression scale. Arch Gen. Psychiatry. 1965;13:63-70.

13 Dijkstra P. The self-rating depression scale of Zung (in Dutch), In: Praag HM van, Rooymans HGM (eds) Stemming en ontstemming. De Erven Bohn BV, Amsterdam; 1975:56-67.

14 Mishan EJ. Loss of life and limb. In: Mishan EJ cost-benefit analysis. London and New York: Routledge; $1988: 330-356$.

15 Corman, ML., Colon and rectal surgery, 3rd Edition, JB. Lippincott Company, 1993.

16. Williams NS, Johnston D. (1983) The quality of life after rectal excision for low rectal cancer. B J Surg. 1983;71:460-462.

17 Dewlin, H. B., Plant, J. A. and Griffin, M. Afrermath of surgery for anorectal cancer. BMJ. $1971 ; 3: 413-418$.

18 Wirsching M, Druner HU, Hermann G. Results of psychosocial adjustment to long term colostomy. Psychother Psychosom 1975;26:245-256

19 MacDonald LD and Anderson HR. The health of rectal cancer patients in the community. Eur J Surg Oncol. 1985;11:235-241.

20 La Monica G, Audisio RA, Tamburini M, Filiberti $A$, Ventafridda $V$. Incidence of sexual dysfuction in male patients treated surgically for rectal malignancy. Dis. Colon Rectum $1985 ; 28: 937-940$.

21 Frigell A, Ottander M, Stenbeck $H$ and Pahlman L. Quality of life of patients treated with abdominoperineal resection or anterior resection for rectal carcinoma. Ann. Chir. gynaecol. $1990 ; 79: 26-30$. 
22 Sprangers MAG, Taal BG, Aaronson NK, te Velde A. Quality of life in colorectal cancer: stoma ws. nonstoma patients. Dis collon Rectum 1995;38:361-369.

23 Leter of the Health Insurance Council to the Board of Directors of the University Hospital Malstricht, the Netherlands; 28 september 1995. 


\section{Comparison prior to and after transplantation of pancreas-kidney and pancreas-kidney with loss of pancreas, a prospective controlled Quality of Life study}

This chapter was originally published under the title:

Comparison prior to and after transplantation of pancreas-kidney and pancreaskidney with loss of pancreas. Adang EMM, Engel GL, van Hooff JP, Kootstra G. Transplantation 1996;62;6:754-758. 


\section{Summary}

The aim of combined pancreas-kidney transplantation (PKT) in type I diabetic patients with end-stage nephropathy is to restore both functions. Quality of life $(\mathrm{QoL})$ is supposed to improve as a result of this combined transplantation. The objectives of this study are to evaluate QoL prior to and after PKT and to compare the results with patients in whom the pancreas graft failed soon after the transplantation (PKT-P).

The trial is a prospective controlled multicenter study. The control group consists of patients before transplantation and patients who received a PKT in whom the pancreas rejected or thrombosed soon after the transplantation (PKT-P). A standardized home-based interview is done during dialysis, and repeated 5,12 and 18 months after transplantation in both groups by the same interviewer. The interview consisted of disease-specific questions (RSCL), general questionnaires (NHP I and II, ABS), the Visual Analogue Scale, a specific questionnaire (Anxiety) and evaluative questions about social support and transplantation.

Patients in whom the PKT is successful $(\mathrm{n}=17)$, improve significantly or show a strong tendency towards improvement on many aspects of quality of life. Patients in whom the pancreas failed $(\mathrm{n}=5)$ still demonstrate improvement, although this is not statistically significant in most cases. Intergroup comparison shows that PKT patients are less anxious, suffer of less itching, have better average daily living conditions, have no diet restrictions and have a better global quality of life.

\section{Introduction}

Insulin-dependent (type I) diabetes mellitus (IDDM I) affects from one to two million people in the United States. ${ }^{1}$ About 30,000 new cases are diagnosed each year, and the incidence is increasing.' In the Netherlands the incidence of male childhood Type I diabetes mellitus is rising rapidly from 1.85/1000 (birth date 1960) to $2.12 / 1000$ (birth date 1970 ). ${ }^{2}$ IDDM I is associated chronically with specific micro vascular complications that include retinopathy, nephropathy, and neuropathy.. ${ }^{3}$ Pancreas transplantation (PTx) establishes a constant normoglycemic state and offers a potential cure for IDDM. ${ }^{4}$ Combined pancreas-kidney transplantation (PK'T) is an accepted treatment option in carefully selected IDDM patients with End-Stage Renal Disease (ESRD). The positive effect of PKT on micro- and macroangiopathy remains a subject of debate. ${ }^{4.5}$ Besides discussion about the effect of PKT on micro- and macroangiopathy, a debate has emerged about whether the combined procedure improves quality of life (QoL) and has additional $\mathrm{QoL}$ benefit compared with a single kidney transplantation (KTx) or pancreas-kidney transplantation with loss of pancreas (PKT-P). ${ }^{6.22}$ These studies, except one ${ }^{20}$, found 
that PKT offered a better QoL, although the difference was not always significant. Most of these studies had a cross-sectional retrospective design, few a prospective controlled design. The aim of this study was to describe in a prospective longitudinal way the QoL of IDDM type I patients with ESRD before and after PKT and to compare these data with the QoL of type I diabetic patients with ESRD who received a PK T in which the pancreas graft failed soon after the transplantation (PKT-P).

\section{Patients and Methods}

In a multicenter setting a prospective longitudinal design was employed in which 38 IDDM patients on dialysis completed a baseline QoL, that was assessed by interviewing the patients at home. The inclusion period was from June 1992 till January 1994. All patients who received a PKT during this period and had a successful PKT or who lost the pancreas soon after transplantation and had a well functioning kidney were kept in the study. These patients were part of a consecutive series of transplants according to the inclusion criteria (PK'T or PKT-P). After transplantation 17,16 and 15 patients with a functioning kidney and pancreas were interviewed at respectively 5, 12 and 18 months. The QoL of 5 patients with functioning kidney and rejected or thrombosed pancreas was assessed at 5,12 and 18 months. Demographic characteristics of both patient groups are displayed in table 1. 
Table 1 Sociodemographic characteristics of type I diabetic patients with successful PKI and patients with PKT-P before transplantation.

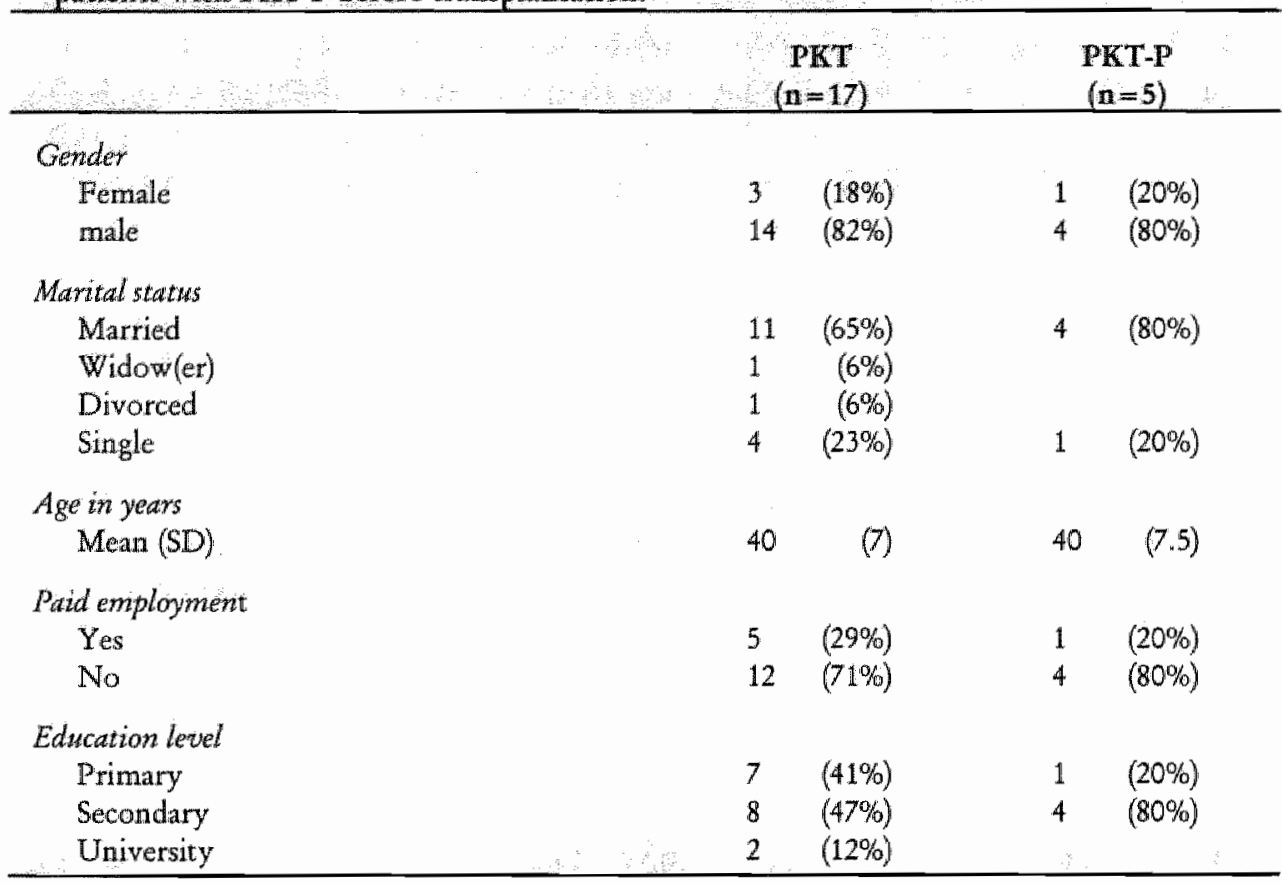

QoL was assessed by interviewing patients at home by the same qualified interviewer (EA), using a standardized patient-based booklet consisting of several questionnaires. QoL was defined by the patients' perception of performance in four areas: physical and occupational function, mental state, social interaction, and somatic sensation. The questionnaires selected to measure these aspects of QoL were the following:

- A Visual Analogue Scale (VAS), a 10-centimetre line ranging from "worst possible QoL' to 'best possible QoL', was used to evaluate and quantify subjective global QoL.

- The Nottingham Health Profile I (NHP-1), which is a comprehensive measure for perceived healtin on 6 specific dimensions of life (mobility, pain, energy, sleep, social isolation, and emotional reaction). The NHP-1 ranges from $O$ (no health problems) to 100 (many health problems). Global reference values for a general population are equal for all dimensions, namely $15 .^{23,24}$

- The Nottingham Health Profile II (NHP-2) relates to those areas of "task performance" most affected by health. Seven statements refer to the effects of health problems on occupation, ability to perform tasks around the home, personal relationships, sex life, social life, hobbies and holidays. The score ranges from 7 (no problems) to 21 (many problems). ${ }^{23,24}$ 
- The State Trait Anxiery Inventory (STAI-D1), which specifically measures anxiery. ${ }^{25,26}$

- A disease specific measure, the Rotterdam Symptom CheckList (RSCL) ${ }^{27}$, adjusted for longstanding IDDM patients. This questionnaire measures generic and disease-specific physical complaints such as fatigue, muscle cramps, insensibility in hands and feet, nausea, itching, painful joints, insomnia, headache, dizziness, sexual problems, gastric acid, abdominal pain, short of breath, tingling hands and feet and difficulty in urinating.

- The Affect Balance Scale (ABS), which measures general well-being. Interpretation of the ABS score is <2: general well-being less than average, 2: average and $>2$ : above average. ${ }^{28,29}$

- The Family Impact Questionnaire, which measures perceived social support (emotional as well as practical support).

- Furthermore, questions were formulated to determine the burden of treatment, diet restrictions, satisfaction with treatment, and evaluation of diabetes.

\section{Statistical analysis}

Based on the small sample size in both groups all data are first analysed nonparametrically and presented as frequency distribution showing median, minimum, and maximum values. For statistical analysis of intragroup differences, the Wilcoxon signed rank test for matched pairs was used. Intergroup (PKT versus PKT-P) differences are measured with the Mann-Whitney $U$ test. Relationships between disease specific aspects and global QoL were determined by Spearman correlation coefficients. In addition to the above mentioned non-parametric tests, the problem of multiple comparisons over time within groups was accounted for by using for instruments that produce normally distributed data (KolmogorovSmirnov), a Repeated Measures ANOVA corrected by the Greenhouse-Geisser procedure. P-values based on this parametrical procedure are marked by an asterisk. We used a conservative approach towards statistical significance. For data that are not normally distributed a more restricted significance level is set at 0.0125 using the standard Bonferroni approach. All data analysis was done using SPSS-pc version 6.1 for Windows.

\section{Results}

As shown in Table 1, the two groups were similar with respect to sociodemographic characteristics, including gender, marital status, age, paid employment and educational level. Intragroup comparison on the variable "paid employment" 
showed, at 12 and 18 months after transplantation in the PKT group, an increase in paid employment of two patients $(\mathrm{p}=0.1797)$. The PKT-P group showed an increase for one patient who resumed work 5 months after transplantation $(p=0.3173)$.

Global QoL measured with the VAS increased significantly in the PKT group $\left(p=0.0010 ; p=0.000^{*}\right)$. For patients in the PKT-P group global QoL did not increase significantly $(\mathrm{p}=0.0679 ; \mathrm{p}=0.045 \%)$, although there was a strong tendency toward improvement. The PKT patients had a better global QoL at 18 months than the PKT-P patients $(\mathrm{p}=0.0554)$ (Figure 1 and Table 2). Over time both groups did not differ significantly from each other $\left(p=0.656^{*}\right)$.

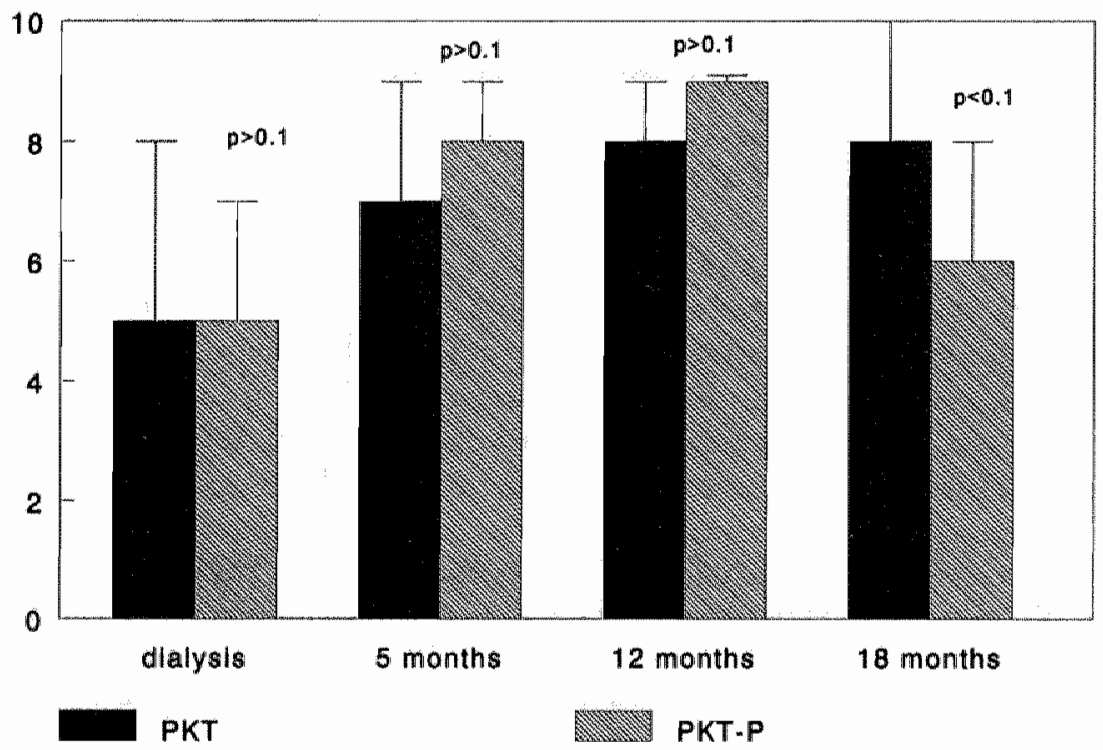

Figure 1 Prospective Global QoL of combined pancreas/kidney transplantation (PKT) and kidney transplantation (PKT-P) measured on a visual analogue scale (VAS)

Data presented as median and maximum values

VAS Outcome (in centimetre-range: 0 -10 centimetre)

Vertical Axes: Range VAS in centimetre

Horizontal Axes: Measurement periods/Follow-up

Intergroup comparison PKT versus PKT.P(Mann Whitney U test) at dialysis, 5 months

(PKT:n 17; PKT-P:n = 5), 12 months (PKT:n=16;PKT-P:n = 5), 18 months (PKT:n=15;PKT-

$P_{: n}=5$ ) after transplantation. 
The disease-specific questionnaire showed that PKT patients were significantly less fatigued $\left(p=0.0409 ; p=0.042^{*}\right)$, less nauseated $(p=0.0117 ; p=0.093 \%$, suffered significantly less itching $\left(p=0.0022 ; p=0.001^{*}\right)$ and had a tendency to have less painful joints $\left(p=0.0630 ; p=0.131^{*}\right)$ than during their dialysis period. On the other hand they suffered from abdominal pain $\left(p=0.0431 ; p=0.065^{*}\right)$. The PKT.P patients showed an almost similar pattern, having less fatigue $(\mathrm{p}=0.1088 ; \mathrm{p}=0.089 \%$, being less nauseated $\left(p=0.1088 ; p=0.155^{*}\right)$ and having less itching $\left(p=0.1088 ; p=0.160^{*}\right)$. Intergroup comparison showed that the PKT patients had significantly less itching at 12 months after transplantation $(\mathrm{p}=0.0094)$. At 18 months no significant difference in itching was noticed. The PKT patients also seemed to have less painful joints $(p=0.1292)$. Itching correlated significantly with global QoL in the PKT group $(r=-0.6100, p<0.01)$.

For the NHP-1, the scores on the dimensions "mobility" and "energy" in both groups were above reference scores for a general population. A significant improvement on the dimension "energy" $\left(p=0.0041 ; p=0.002^{*}\right)$ and a tendency toward greater "mobility" was found in intragroup comparison of the PKT patients. In the PKT-P group there was a tendency towards improvement on "mobility" $\left(\mathrm{p}=0.1088 ; \mathrm{p}=0.234^{*}\right)$ and "energy" $\left(\mathrm{p}=0.1088 ; \mathrm{p}=0.090^{*}\right)$. Comparison of PKT patients with PKT-P patients showed no significant differences. NHP-1 data are displayed in Table 2.

The PKT patients increased significantly on the NHP-2 $\left(\mathrm{p}=0.0120 ; \mathrm{p}=0.025^{*}\right)$. The PKT-P patients showed, although it was not significant, a similar pattern $\left(p=0.0679 ; p=0.111^{*}\right)$. Intergroup comparison showed no differences (Figure 2). 


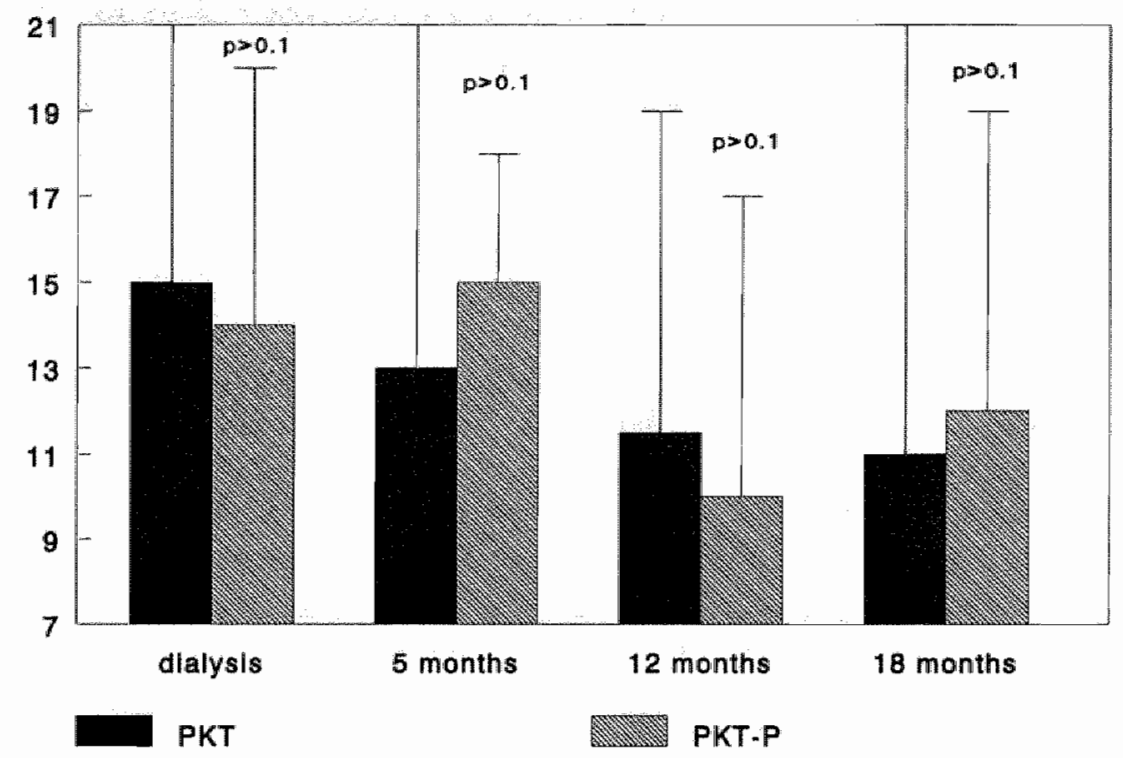

Fïgure 2 Prospective course of performance on daily activities after combined pancreas/kidney transplantation (PKT) and kidney transplantation (PKT-P)

Data presented as median and maximum values

Outcone range 7.21

The lower the score the less problems with performance in daily life.

Vertical Axes: $\quad$ Score on NHP-II

Horizontal Axes: Measurement period/Follow-up

Intergroup comparison PK'T versus PKT-P(Mann Whitney U test) at dialysis, 5 months

(PKT:n=17;PKT-P:n-5), 12 months (PKT:n= 16;PKT-P:n=5), 18 months (PKT:n=15;PKT.

P:n $=5)$ after transplantation.

The ABS showed for the PKT group a tendency towards improved well-being $(p=0.1579)$. The PKT-P group showed a less clear pattern. Furthermore intergroup comparison showed that at 18 months the PKT patients had a better "well-being" score than the PKT-P group $(\mathrm{p}=0.1102)$ (Table 2).

PKT patients became significantly less anxious $(p=0.0340$ at 12 months and $\mathrm{p}=0.0115$ at 18 months). Over time PKT patients showed a less clear result 
$\left(p=0.136^{*}\right)$. The PKT-P patients showed a significant decrease in anxiety later on during their follow-up period $(p=0.0431$ at 18 months). Interpretation of the STAI resulted in a change from moderately anxious on dialysis to not anxious after transplantation. Intergroup comparison showed no significant differences (Figure 3).

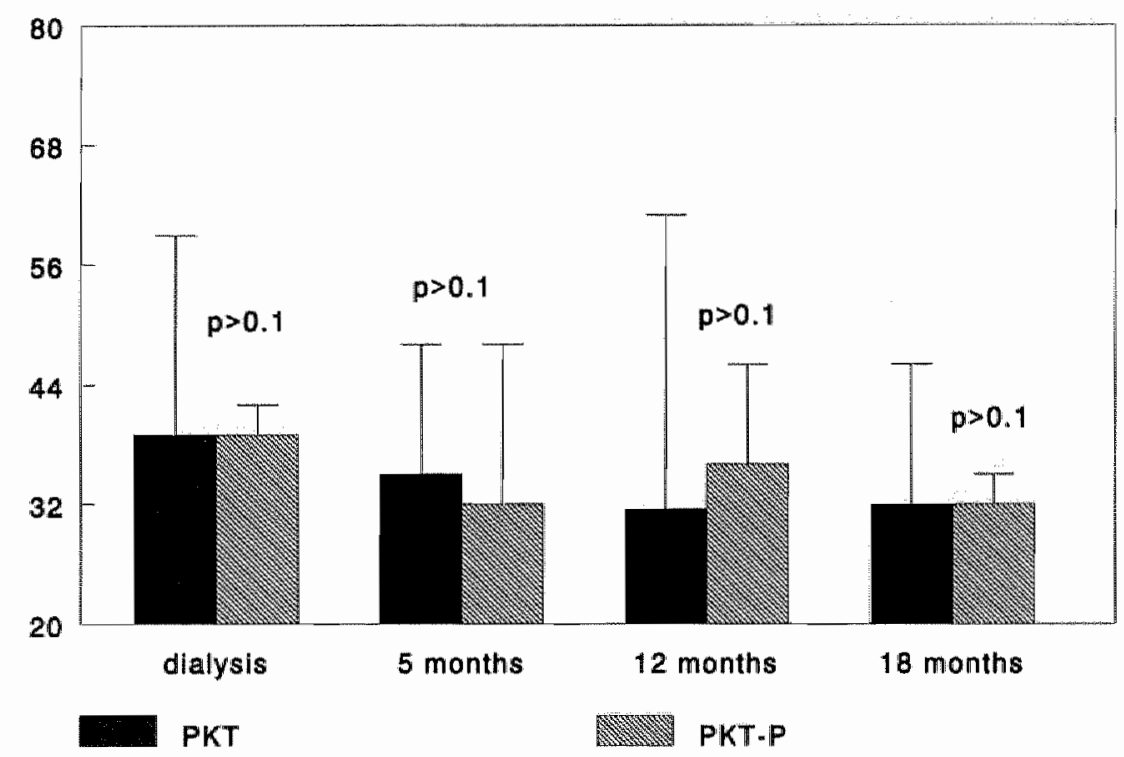

Figure 3 Prospective course of anxiety after combined pancreas/kidney transplantation (PKT) and kidney transplantation (PKT-P)

Data presented as median and maximum values

Outcome interpretation

20-38:

not anxious

39-46: $\quad$ moderatelly anxious

47-80: $\quad$ extremely anxious

Vertical Axes: level of anxiety

Horizontal Axes: Measurement period/Follow-up

Intergroup comparison PK'T versus PKT-P(Mann Whitmey U test) at dialysis, 5 months

$(\mathrm{PKT}: \mathrm{n}=17 ; \mathrm{PKT}-\mathrm{P}: \mathrm{n}=5), 12$ months $(\mathrm{PKT}: \mathrm{n}=16 ; \mathrm{PKT} \cdot \mathrm{P}: \mathrm{n}=5)$, 18 months (PKT:n $=15 ; \mathrm{PKT}$ -

P:n $=5$ ) after transplantation. 
Table 2 Quality of Life scores

\begin{tabular}{|c|c|c|c|c|c|c|c|c|}
\hline Instruments & \multicolumn{2}{|c|}{$\begin{array}{c}\text { Dialysis } \\
\text { PKT/PKT-P }\end{array}$} & \multicolumn{2}{|c|}{$\begin{array}{c}\text { PKT1 } \\
\text { PKT-P1 }\end{array}$} & \multicolumn{2}{|c|}{$\begin{array}{l}\text { PKT2 } \\
\text { PKT-P2 }\end{array}$} & \multicolumn{2}{|c|}{$\begin{array}{c}\text { PKT3 } \\
\text { PKT-P3 }\end{array}$} \\
\hline Global QoL & $\begin{array}{l}5 \\
5\end{array}$ & $\begin{array}{l}(2,8) \\
(4,7)\end{array}$ & $\begin{array}{l}7 \\
8\end{array}$ & $\begin{array}{r}(5,9)^{*} \\
(5,9)\end{array}$ & $\begin{array}{l}8 \\
9\end{array}$ & $\begin{array}{r}(5,9)^{*} \\
(5,9)\end{array}$ & $\begin{array}{l}8 \\
6\end{array}$ & $\begin{array}{r}(4,10) \text { 怔 } \\
(5,8)\end{array}$ \\
\hline$A B S$ & $\begin{array}{l}2 \\
2\end{array}$ & $\begin{array}{l}(-1,5) \\
(-2,4)\end{array}$ & $\begin{array}{l}2 \\
2\end{array}$ & $\begin{array}{r}(-2,5) \\
(0,3)\end{array}$ & $\begin{array}{l}3.5 \\
4\end{array}$ & $\begin{array}{l}(0,5) \\
(1,4)\end{array}$ & $\begin{array}{l}3 \\
0\end{array}$ & $\begin{array}{l}(-1,5) \\
(-1,4)\end{array}$ \\
\hline $\begin{array}{l}\text { NHP.1 } \\
\text { Mobility }\end{array}$ & 22 & $(0,66)$ & 11 & $(0,56)$ & 6 & $(0,68)$ & 13 & $(0,67)$ \\
\hline Pain & $\begin{array}{l}22 \\
0 \\
0\end{array}$ & $\begin{array}{l}(0,44) \\
(0,70) \\
(0,0)\end{array}$ & $\begin{array}{l}11 \\
0 \\
0\end{array}$ & $\begin{array}{l}(0,54) \\
(0,37) \\
(0,31)\end{array}$ & $\begin{array}{l}11 \\
0 \\
0\end{array}$ & $\begin{array}{r}(0,31) \\
(0,51) \\
(0,6)\end{array}$ & $\begin{array}{l}0 \\
0 \\
0\end{array}$ & $\begin{array}{r}(0,22) \\
(0,47) \\
(0,0)\end{array}$ \\
\hline Energy & 39 & $(0,100)$ & 0 & $(0,63)^{*}$ & 0 & $(0,63)^{*}$ & 0 & $(0,63)^{* H}$ \\
\hline & 24 & $(0,100)$ & 0 & $(0,61)$ & 0 & $(0,61)$ & 0 & $(0,37)$ \\
\hline Sleep & $\begin{array}{l}0 \\
0\end{array}$ & $\begin{array}{r}(0,100) \\
(0,66)\end{array}$ & 0 & $\begin{array}{l}(0,34) \\
(0,66)\end{array}$ & $\begin{array}{l}0 \\
0\end{array}$ & $(0,50)$ & $\begin{array}{l}0 \\
0\end{array}$ & $\begin{array}{l}(0,16) \\
(0,35\end{array}$ \\
\hline Social isolation & 0 & $(0,62)$ & 0 & $(0,62)$ & 0 & $(0,42)$ & 0 & $(0,58)$ \\
\hline Emotional reaction & $\begin{array}{l}16 \\
0 \\
9\end{array}$ & $\begin{array}{l}(0,23) \\
(0,37) \\
(0,37)\end{array}$ & $\begin{array}{l}16 \\
0 \\
0\end{array}$ & $\begin{array}{l}(0,84) \\
(0,35) \\
(0,45)\end{array}$ & $\begin{array}{l}16 \\
0 \\
7\end{array}$ & $\begin{array}{r}(0,42) \\
(0,44) \\
(0,14)\end{array}$ & $\begin{array}{l}0 \\
0 \\
10\end{array}$ & $\begin{array}{l}(0,84) \\
(0,31) \\
(0,17)\end{array}$ \\
\hline NHP-2 & $\begin{array}{l}16 \\
14\end{array}$ & $\begin{array}{r}(8,21) \\
(12,20)\end{array}$ & $\begin{array}{l}13 \\
15\end{array}$ & $\begin{array}{c}(7,21)^{*} \\
(7,18)\end{array}$ & $\begin{array}{l}12 \\
10\end{array}$ & $\begin{array}{r}(7,19)^{*} \\
(8,17)\end{array}$ & $\begin{array}{l}11 \\
12\end{array}$ & $\begin{array}{r}(7,21)^{x} \text { \# } \\
(7,19)\end{array}$ \\
\hline
\end{tabular}

* Intragroup statistical significance; Dialysis compared to PKT1/PKT-P1, PKT2/PKT-P2, PK'T3/PKT-P3 (Wilcoxon Signed Ranks Test).

\# $\approx$ Within group statistical significance (Repeated Measures ANOVA)

Data presented as median (minimum,maximum) values

PKT1 and PKT-P1 $=$ PKT $(n=17)$ and PKT-P $(n=5)$ at 5 months after transplantation

$P K ' T 2$ and PKT-P2 $=$ PKT $(n=16)$ and PKT.P $(n=5)$ at 12 months after transplantation

PKT'3 and PKT-P3 $=$ PK'T $(n-15)$ and PKT-P $(n=5)$ at 18 months after transplantation

The family Impact questionnaire showed, for the PKT group, a decreased need for emotional support at 18 months $(p=0.0745)$. Their environment reflected this phenomenon and offered less emotional support $(p=0.1682)$. For practical support there was the same pattern, although not as clear as for emotional support. PKT parients upgraded their role performance at home $(p=0.0687)$. The PKT-P group showed no clear pattern with regard to support and role performance at home.

In the PKT group all except one, who had become a type II diabetic, no longer had any diet restrictions. Comparison of the PKT group with the PKT-P group showed significant differences with regard to diet restrictions $(p=0.0001)$. For the PKT group there was no longer any need to regulate blood glucose levels. The PKT$P$ group still had to cope with that problem, although there was a tendency towards fewer problems in regulating these blood glucose levels. 
Finally, the transplantation was evaluated by asking the patients in retrospect, if they would again choose to have the transplantation, and, if affirmative, what kind of transplantation they would prefer a combined pancreas/kidney or a single kidney. All patients in both groups did choose transplantation again, without hesitation. On the question of which kind of transplantation there was less agreement. The PKT patients all again chose combined pancreas kidney transplantation. The PKT-P group was divided; at 5 and 12 months 4 of 5 had chosen the combined, and at 18 months 3 of 5 chose the combined. This led to a significant difference in transplantation evaluation between the PKT and the PKT-P group $(\mathrm{p}=0.0118)$.

\section{Discussion}

PKT and PKT-P groups rated their QoL higher compared with dialysis. This was observed not only in the overall QoL rating (VAS) but also in variables, objective and subjective, contributing to QoL, especially work resumption, itching, energy, task performance and anxiety. These findings are widely confirmed by the results of previous studies $^{6.22}$ in which a successful PKT has been compared with a kidney transplant alone or with $\mathrm{PKT}$ with a pancreas graft that failed shortly after transplantation. Although the QoL scores in both groups were high, reflecting a quite satisfactory level of QoL, the scores in the PKT group were even higher on several components. The PKT patients achieved, at 18 months, a better global QoL on the VAS. Furthermore, in this group there were fewer problems with itching and task performance in daily life. Anxiety was less at 12 months; this could be explained by the fact that the PKT-P patients had to cope with the loss of the pancreas. After 18 months there was no clear difference berween both groups with respect to anxiety. There was less need for emotional support and there seemed to be less need for practical support in the PKT group. This group no longer had diet restrictions and had stable blood glucose levels compared with the PKT-P patients who still had diet restrictions and a need to regulate their blood glucose levels with insulin injections. On the other hand, it was easier for PKT-P patients to regulate their blood glucose levels than during their diallysis period.

Because of the small sample size of the PKT-P group the results should be interpreted with caution. Failure to reach significance in intra- and intergroup comparison on several aspects of QoL could be caused by small sample size. Furthermore, the study design produces a negative bias for the PKT-P group. A better controlled comparison might be between clinically identical patients who were randomly assigned to a PKT or to a KTx. In such a setting the KTx patients had no pancreas rejection and bear less risk from the operation. ${ }^{30}$ Also pancreas/kidney recipients require twice as long a period of hospitalization for the 
transplantation and two times as many readmissions for a variety of complications., ${ }^{9,31}$ The failure rate is higher than that of kidney transplantation. ${ }^{30}$ On the other hand duabetic retinopathy and other secondary complications have said to improve after the combined operation. ${ }^{5,32,33}$ Results found by others are in conflict with these findings. ${ }^{34}$ Unfortunately such a well-controlled design is not possible because of the inability to randomize patients to kidney vs. pancreas/kidney transplantation." In our multicenter study it was regarded as unethical.

In the absence of a demonstrable effect on long-term diabetic complications graft survival, and QoL, one should base a conclusion on the short term. In the short term one should weigh a better QoL, no diet restrictions, and good control of glucose levels against an increase in hospitalization and complications of surgery.

Furthermore, it should be noted that QoL increases even if the pancreas is lost soon after the transplantation.

\section{Acknowledgement:}

This study was supported by (1) the Fund for Investigational Medicine (Ontwikkelingsgeneeskunde), the Netherlands and (2) the Fund for Outstanding and Competitive Clinical Research (Profileringsfonds), University Hospital Maastricht; the Netherlands.

\section{References}

1 Libman I, Songer T, Laporte R. How many people in the US have IDDM? Diabetes Care 1993; 16:841-842.

2 Drykoningen CEM, Mulder ALM, Vaandrager GJ, LaPorte RE, Bruining GL. The incidence of male childhood 'T'ype I (insulin-dependent) diabetes mellitus is rising rapidly in the Netherlands. Diabetologia 1992;35:139-142.

3 Nathan DM. Long-term complications of diabetes mellitus. N Engl J Med 1993;328:1676-1684.

4 Sutherland DE, Goetz FC, Najarian JS. Pancreas transplantation for diabetes. Lancet 1988::11:00.

5 Kennedy WR, Navarro X, Goetz FC, Sutherland DER, Najarian JS. Effects of pancreatic transplantation on diabetic neuropathy. N Engl J Med 1990:322:1031.

6 Nakache R, Tyden G, Groth CG. Quality of life in diabetic patients after combined pancreaskidney or kidney transplantation. Diabetes 1989:38:40-42.

7 Voruganti LN, Ses RA. Quality of life of diabetic patients after combined pancreatic-renal transplantation. Clin Transplantation 1989:3:78-82.

8 Corry RJ, Zehr P. Quality of life in diabetic recipients of kidney transplants is better with the addition of the pancreas. Clin Transplantation 1990:4:238-241. 
9 Nathan DM, Fogel H, Norman D, et. al Long-term metabolic and quality of life results writh pancreatic/renal transplantation in insulin-dependent diabetes mellitus. transplantation 1991:152:85-91.

10 Piehlmeier W, Bullinger M, Nusser J, et. al. Quality of life in Type I (insulin dependent) diaberic patients prior to and after pancreas and kidney transplantation in relation to organ function. Diabetologia 1991:34:150-157.

11 Secchi A, Di Carlos V, Martinenghi $S$, et. al. Effect of pancreas transplantation on life expectancy, kidney function and quality of life in uraemic- Type I (insulin-dependent) diabetic patients. Diabetologia 1991:34:141-144.

12 Zehrer CL, Gross CR. Quality of life of pancreas transplants recipients. Diabetologia 1991:34:138-140.

13 Gross CR, Zehrer CL. Health-related quality of life outcomes of pancreas transplant recipients. Clin Transplantation 1992:6:165-171.

14 Milde FK, Hart LK, Zehr PS. Quality of life of Pancreatic Transplant Recipients. Diabetes Care 1992:15:1459-1463.

15 Zehrer CL, Gross CR. Comparison of Quality of Life between Pancreas/Kidney and Kidney Transplant Recipients: 1-Year Follow-up. Transplantation Proceedings 1.994:26:2:508-509.

16 Nakache $R$, Tyden $G$, Groth $C G$. Long-Term Quality of Life in Diabetic Patients after combined Pancreas-Kidney Transplantation or Kidney Transplantation. Transplantation Proceedings 1994:26:2:510-511.

17 Hathaway DK, Hartwig MS, Milstead J, Elmer D, Evans S, Gaber AO. Improvement in Quality of Life Reported by Diabetic Recipients of Kidney-Only and Pancreas-Kidney Allografts. Transplantation Proceedimgs 1994:26:2:512-514.

18 Gaber AO, Hathaway T, Abell S, Cardoso S, Hartwig MS, EL Gebely S. Improved Autonomic: and Gastric Function in Pancreas-Kidney vs Kidney-Alone Transplantation Contributes to Qualisty of Life. Transplantation Proceedings 1994:26:2:515-516.

19 Zehr PS, Milde FK, Hart LK, Corry RJ, Hunsicker LG. Impact of Pancreas Transplantation on Quality of Life of Diabetic Renal Transplant Recipients. Transplantation Procedings 1994:26:2:520-521.

20 Piehlmeier W, Bullinger M, Kirchberger I, et. all. Prospective study of the Quality of Life in Type I Diabetic Patients Before and After Organ Transplantation. Tramsplantation Proceedings 1994:26:2:522-523.

21 Kiebert GM, van Oosterhout ECAA, wan Bronswijk H., Lemkes HHPJ, Gooszen HG. Quality of life after combined kidney-pancreas or kidney transplantation in diabetic patients with end-stage renal disease. Clin Transplantation 1994:8:239:245.

22 Esmatjes E, Ricart MJ, Fernandez-Cruz L, et. al. Quality of life after successful pancreas-kidney transplantation. Clin Transplantation 1994:8:75-78.

23 Hunt SM, McEwen J, McKenna SP. Measuring Health Status: A new tool for clinicians and epidemiologists. Journal of Royal College of General Practitioners. 1985;35:185-188.

24 Stouthard MEA, Bonsel GJ. Nederlandse bewerking NHP-DA, 1991.

25 Spielberger CD, Gorsuch RL, Lushene RE (eds). STAI manual for the state-trait anxiety inventory. Consulting Psychologists Press Inc. Palo Alto, California, 1970. 
26 Ploeg HM van der, Defares $P B$, Spielberger $C D$. Een Nederlandstalige bewerking van de Spielberger State-Trait Anxiety Inventory: de Zelfbeoordelings Vragenlijst. De Psycholoog $1980 ; 15: 460-467$.

27 Haes JCJM de, Kinippenberg FCE wan, Neijt JP. Measuring psychological and physical distress in cancer patients: Structure and application of the Rotterdam Symptom, CheckList. Br J Cancer, $1990 ; 62: 1034-1038$.

28 Bradburn NM. The structure of psychological well-being. Chicago: Aldine, 1969.

29 CBS. Leefsituatie Nederland:Kernciffers 1983.:p.87.

30 Remuzzi $G$, Ruggenenti P, Mauer SM. Pancreas and kidney/pancreas transplants: experimental medicine or real improvement? Lancet 1994;343:27-31.

31. Stratta RJ, Taylor RJ, Bynon J, et. all. Surgical treatment of diabetes mellitus with pancreas transplantation. Ann Surg. 1994:220:6:809.817.

32 Bilous $\mathbb{R} W$, Mauer $M$, Sutherland DER, et.al. The effects of pancreas transplantation on the glomerular structure of renal allografts in patients with insulin-dependent diabetes. $\mathrm{N}$ Engl J Med 1989;321:80.

33 Landgraf $\mathrm{R}, \mathrm{Nusser} J$, Muller $\mathrm{W}$, et al. Fate of late complications in type I diabetic patients after successful pancreas-kidney transplantation. Diabetes 1989;38(suppl 1):33-37.

34 Ramsay RC, Goetz FC, Sutherland DER, et al. Progression of diabetic retinopathy after pancreas transplantation for insulin-dependent diabetes mellitus. N Engl J Med 1988;318:208214. 


\section{In chronically ill patients, retrospective, post- treatment quality of life reports result in misleading data}

Parts of this chapter are submitted under the titles:

Quality of life ratings in patients with chronic illnesses. Adang EMM, Kootstra G, Engel GL, Baeten CGMI. JAMA 1997;277;13:1038.

Do type I diabetic patients with end-stage renal disease adapt to their illness? A study in Pancreas Kidney Transplant patients. Adang EMM, Kootstra G, Engel GL, Hooff van JP, Merckelbach HLGJ. (Submitted) 


\section{Summary}

Literature indicates that chronically ill patients have a remarkable capacity to adapt to their illness. For example, they will generally report better quality of life than individuals in the general population who are asked to imagine and rate their quality of life with chronic illnesses. The present study further explores this phenomenon.

A prospective longitudinal study was performed to assess quality of life in 22 parients with type I diabetes and end-stage renal disease both before and after they received a combined pancreas-kidney transplant. In addition, after their transplants, patients were asked to assess their pre-transplant quality of life. Quality of life was assessed by asking patients to report their quality of life on a 10 point scale with higher values indicating better self-reported quality of life.

Analyses revealed that before transplantation quality of life was prospectively assessed at 5.23 and increased to 7 after successful transplantation. At follow-up measurements after successful transplantation, patients retrospectively assessed their pretransplant quality of life at $3.27,3.14$, and 3.05 , respectively. Thus, when chronically ill patients undergo an intervention to improve their health status, they underestimate their pre-intervention 'quality of life' assessments.

\section{Introduction}

In the past few years 'Quality of Life' (QoL) as an outcome parameter in clinical research has attracted considerable attention. ${ }^{1}$ One reason is the increased prevalence of chronic diseases in an aging society. ${ }^{2}$ For these diseases, the goal of medical interventions is not to cure, but rather has to do with the well-being of patients. Not surprisingly then, in both clinical decisions and policymaking, there is a need to measure health-related QoL in an accurate way. ${ }^{3}$

Gill and Feinstein claim that QoL is a unique personal perception, denoting the way that individual patients feel about their health status and/or nonmedical aspects of their lives. Calman describes QoL as a dimension that can only be measured in individual terms and depends on present lifestyle, experience, hopes for the furure, dreams, and ambitions. ${ }^{5}$ With a modest level of expectations, acceptable subjective well-being is possible, even in objectively awkward circumstances. ${ }^{5}$ Good QoL can be said to be present when the ambitions of an individual are matched and fulfilled by experience. The fact that chronically ill patients adapt to their illness may affect QoL measurement. For example, Cassileth et. al. ${ }^{6}$ found that five groups of physically ill patients (with arthritis, diabetes, cancer, renal disease, and dermatologic disorders) did not differ significantly from one another or from the general population in terms of their mental health scores (e.g., anxiety, depression, 
general positive affect, emotional ties, loss of control, mental health index). O'Boyle et. al. found results that suggest that adaptability and previous experience can substantially modify perception of QoL.?

Adaptation can be described as a process in which past, present, and furure circumstances are interpreted or evaluated such that an acceptable level of wellbeing is achieved. It is assumed that events and situations can, indeed, seriously compromise the subjective feeling of well-being. However, usually, in due course, adaptation takes place, resulting in a level of well-being "belonging to the person". Dramatic events in the past or a decline of an individual's physical condition do not necessarily result in a reduced subjective well-being." Furthermore, current problems may be put in perspective by referring to periods during which the person was worse off. Another strategy to assess one's own situation positively is by comparing one's position with others who appear to be in a more difficult situation. This phenomenon is called downward social comparison. ${ }^{10}$ It is also known that people believe that their future will be better than their present or their past. ${ }^{11}$ In addition, people tend to exaggerate grossly their own likelihood for positive outcomes in the future, and judge themselves less likely than others to experience negative outcomes. ${ }^{12}$ These "positive illusions" illustrate a number of adaptive strategies and mechanisms that individuals tend to apply to restore well-being. It is plausible to assume that the relationship between adaptation and well-being is reciprocal: when a person's feeling of well-being is undermined, adaptive means are mobilised, which subsequently contribute to recuperation. ${ }^{.}$A more detailed overview of the strategies individuals use to overcome misfortune and to restore their subjective well-being is given by Heyink (1993). "This literature demonstrates that chronically ill patients have a remarkable capacity to adapt to their illness, and will generally report better $\mathrm{QoL}$ than individuals in the general population who are asked to imagine and rate their QoL under conditions of chronic illnesses. For example, the study of Tsevat et al. found that self-reported health values of seriously ill patients are higher (i.e., better) than patients" proxies (e.g., family members) believe them to be. ${ }^{13}$ Furthermore, these authors also found that QoL changes with time and, under normal circumstances, can vary considerably.

The current study further explored changes in 'QoL' ratings in chronically ill patients. More specifically, it was investigated whether chronically ill patients who underwent an intervention to improve their health status, lowered, retrospectively, their pre-intervention 'QoL'. Such a pattern of QoL ratings would indicate that this sort of measurements reflect adaptive processes. It would also imply that retrospective $\mathrm{QoL}$ scores are unreliable, precisely because they underestimate the capacity of chronically ill patients to adapt to their illness. 


\section{Patients and Methods}

A prospective longitudinal multicenter study was performed to assess $Q \circ L$ in 22 patients with type I diabetes and end-stage renal disease both before and after they received a combined pancreas-kidney transplant. In addition, patients were asked to estimate their pre-transplant QoL after their transplants. The inclusion period was from June 1992 - January 1994. The present study was part of a larger research project on QoL evaluation. In this study a successful procedure was defined as a procedure which led to a health status in which both kidney and pancreas function properly $(n=17)$, or a health status in which the pancreas is rejected soon after the transplantation $(n=5) .{ }^{14}$

The patients were interviewed at their homes before transplantation (baseline) and at 5, 12, and 18 months after transplantation. During the post-transplant ratings, patients were asked to rate their current $\mathrm{QoL}$ and to estimate QoL before the transplant. Qol was assessed with a Visual Analogue Scale (VAS) that asked patients to report their $\mathrm{QOL}$ on a 10-point scale $(10 \mathrm{~cm})$ ranging from 0 , 'worst possible QoL', to 10, 'best possible QoL'. 'There were several reasons to employ VAS ratings as an index of QoL. To begin with, this measure is easy to understand and requires only little time (about 10 seconds). Furthermore, according to Froberg and Kane ${ }^{15}$, VAS ratings are one of the most promising QoL instruments in terms of reliability, validity, and feasibility. Accordingly, VAS ratings are widely used in QoL research., ${ }^{45}$

In the current study, the QoL measure (i.e., the VAS) was introduced to patients as a subjective health related status. To examine to what extend QoL ratings are related to 'general well-being' and 'future expectations', patients were also asked to complete the Affect Balance Scale (ABS) ${ }^{16,17}$ and a question about these future expectations. The ABS was chosen because it yields an overall aggregate score that is a good index of general well-being. ${ }^{4,14,16,17}$ Furthermore, according to Gill and Feinstein, the ABS is the best available indicator of well-being when it is applied along with its Subjective Rating Scale, similar to the VAS in the present study." The ABS questionnaire includes 10 questions about positive and negative affect, that are evaluated in terms of absent (0) or present (1). Interpretation of the ABS score is as follows: <2:general well-being less than average, 2: average, and $>2$ :above average. ${ }^{16,17}$ It was anticipated that the prospective VAS and ABS scores (baseline, 5,12 and 18 months after transplantation) correlated positively. ${ }^{4}$ However, when patients retrospectively assess their baseline QoL different after an intervention, than it is likely that these retrospective scores do not correlate with the baseline ABS score. During baseline and prospective measurement occasions, patients were also asked:" when you consider the future, what do you expect from your health state in one year?". This made it possible to examine whether future expectations afiect retro- and prospective QoL. 


\section{Statistical Analysis}

VAS scores were tested for normality with a Kolmogorov-Smirnov test. Data were expressed as mean and standard deviation (SD). A repeated-measures ANOVA (within measurements) was used to test the null hypothesis that pre-treatment QoL reports do not differ from retrospective, post-treatment reports. Conservative criteria for statistical significance were applied, using standard Bonferroni correction. With the same approach, the null hypothesis, that the three retrospective post-treatment VAS scores did not differ from each other, was tested. Furthermore, it was tested whether prospective QoL did increase after the transplantation. Due to their ordinal character differences in patients expectations over time were tested non-parametrically with a Wilcoxon Matched-Pairs Signed Ranks Test. The connection between VAS and ABS ratings was investigated by calculating Pearson correlations. Data were analysed by SPSS-pc, version 6.1.

\section{Results}

Two patients were not able to finish the study: one patient suffered from a stroke and could not be interviewed since time point 12 months and the other patient died before 18 months after transplantation. Overall, VAS scores had a normal distribution. Table 1 shows mean VAS scores during pre- and postransplantation measurement points. Analyses revealed that QoL on the VAS was prospectively assessed at 5.23 at baseline and significantly increased to approximately 7 after successful transplantation ( $p<0.001$, table 1 , figure 1 ). 


\section{VAS scores \\ Means and SD}

- retrospective

+ prospective

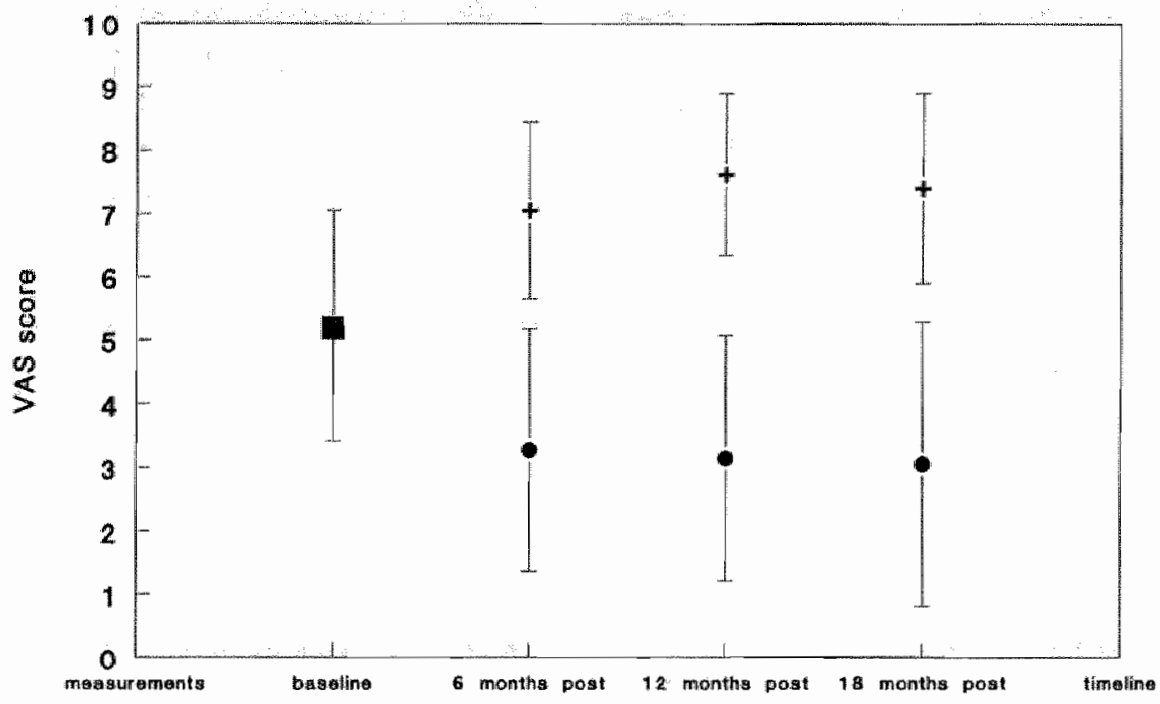

Figure 1 Prospective course of prospective and retrospective VAS scores presented as means and standard deviation

Ar consecutive time points after successful transplantation, patients retrospectively assessed their pretransplant QoL at 3.27, 3.14, and 3.05 (table 1, figure 1). On the basis of these data, the null hypothesis could be rejected $(p<0.001)$. Parameter estimation showed a strong linear trend (coefficient $=-1.755, t-$ value $=4.803, p<0.001)$. Furthermore, the three retrospective posttransplant ratings did not differ from each other $(\mathrm{p}=0.405)$ (table 1$)$. 
Table 1 VAS Means and Standard Deviations (SD)

\begin{tabular}{lcc}
\hline Data & Mean & SD \\
\hline Baseline & 5.23 & 1.82 \\
Re-evaluated pre TX 5 month post & $3.27^{*}$ & 1.91 \\
Re-evaluated preTX 12 month post & $3.14^{*}$ & 1.93 \\
Re-evaluated preTX 18 month post & $3.05^{*}$ & 2.24 \\
Post TX 5 month & $7.05 *$ & 1.40 \\
Post TX 12 month & 7.62 & 1.28 \\
Post TX 18 month & $7.40 \#$ & 1.50 \\
\hline
\end{tabular}

* Significant decrease (Within measurements, $\mathrm{DF}=57,14.27, \mathrm{P}=0.000$ ).

\# Significant increase (Within measurements, $\mathrm{DF}=57,14.94, \mathrm{P}=0.000$ ).

The retrospectively assessed baseline VAS scores did not correlate with the baseline ABS score $\left(r_{\text {stanths }}=-0.076 ; r_{11 \text { manths }}=-0.113 ; r_{18 \text { months }}=-0.100\right.$, respectively $)$. The prospective VAS scores correlated moderately with the ABS scores ( $\mathrm{r}_{\text {bastline }}=$ $0.297 ; r_{\text {mmenths }}=0.575(\mathrm{p}<0.01) ; r_{12 \text { numanths }}=0.484(\mathrm{p}<0.05) ; r_{18 \text { monhhs }}=0.477$ $(p<0.05)$, respectively). Patients' ABS scores increased from 2 at baseline to 3.5 after transplantation, although this improvement was not significant $(p=0.1579)$.

Table 2 shows expectation scores of the patients. Patients" expectations about their future health state changed significantly over time (Wilcoxon Matched-Pairs Signed-Ranks Test; $Z=-2.4962$ (12 months); $Z=-2.3094$ (18 months, $p<0.05$ ), with $59.1 \%$ of them believing in improvement before transplantation and $35 \%$ believing in improvement at 12 and 18 months after transplantation (table 2). Examination of table 2 suggests that data are similar for baseline and 5 months, and similar for 12 and 18 months, with the latter two measurements differing from the former two measurements.

Table 2 Future expectations about Health State

Question asked to the patients: When you consider the future, what do you expect from your Healuh State in one year?'

\begin{tabular}{|c|c|c|c|c|c|c|c|c|}
\hline \multirow{2}{*}{ Answers } & \multicolumn{2}{|c|}{ pre Transplant } & \multicolumn{2}{|c|}{$\begin{array}{l}5 \text { months post } \\
\text { Transplant }\end{array}$} & \multicolumn{2}{|c|}{$\begin{array}{l}12 \text { months post } \\
\text { Transplant }\end{array}$} & \multicolumn{2}{|c|}{$\begin{array}{l}18 \text { months post } \\
\text { Transplant }\end{array}$} \\
\hline & 13 & $(59.1 \%)$ & 14 & $(63.6 \%)$ & 8 & $(38.1 \%)$ & 6 & $(30 \%)$ \\
\hline the same & 5 & $(22.7 \%)$ & 5 & $(22.7 \%)$ & 12 & $(57.1 \%)$ & 13 & $(65 \%)$ \\
\hline worse & $a$ & & 0 & & 0 & & 0 & \\
\hline can't tell & 4 & $(18.2 \%)$ & 3 & $(13.6 \%)$ & 1 & $(4.5 \%)$ & 1 & $(5 \%)$ \\
\hline
\end{tabular}

Data expressed as absolute numbers and (percentages). 


\section{Discussion and Conclusion}

The most important finding of the present study was that prospective QoL judgements differ considerably from retrospective QoL judgements. It was demonstrated that chronically ill patients, who underwent a successful procedure, underestimate their previous self-reported baseline quality of life. From a psychometric perspective, this finding underlines the critical difference between quality of life ratings pertaining to the current situation and those pertaining to a previous time period. Based on these findings one can conclude that studies assessing QoL in chronically ill patients in a retrospective fashion lead to different conclusions than studies relying on prospective QoL.

A likely explanation for this phenomenon is adaptation to illness during the pretransplant period. It is intuitively plausible to assume that patients' expectations about their health status at baseline were heightened because of the prospect for a cure for both nephropathy and diabetes. Thus, one could argue that expectations about their future health state, influence the baseline QoL score. Yet, note that, there appeared to be little or no difference with regard to future expectations about health state between the pre-treatment and 5 month post-treatment evaluations, even though QoL scores (i.e., VAS scores) were different. Presumably, this difference in VAS score related to change in health status and not future expectations. In addition, serial QoL assessments after transplantation did not seem to reflect the dramatic changes in future expectations about health (table 1 and 2). As said earlier, adaptation refers to strategies individuals use to overcome misfortune and to restore their subjective well-being. A shift in one or several of these strategies will change perceived, retrospective QoL after transplantation. If, under influence of the transplantation, the patients' attitude towards the adaptive strategies has changed, measurement of the patients' QoL cannot be interpreted properly because after the transplantation the patient operates as a differently calibrated person with regard to adaptational strategies. This response shift, rather than future expectations or well-being provides an explanation for the difference between actual and retrospective QoL.

Using the same instrument (VAS) Kiebert et al. ${ }^{18}$ found in a retrospective, crosssectional study with a similar patient group (type I diabetic patients with ESRD), that after an unsuccessful transplantation (rejection of both pancreas and kidney), patients tend to upgrade in retrospect their perception of experienced QoL before transplantation. In contrast, the present results show that after a successful transplantation, patients underestimate QoL of their baseline state. Thus, it seems that variations in QoL are outcome dependent.

Several studies have assessed the ability of respondents to recall their health states using identical questions administered to the same individuals at a later point in time. ${ }^{19,20,21,22} \mathbb{H e r m a n n}^{19}$ acknowledged recall bias as a possible distortion factor in 
retrospective designs. Howard et al. ${ }^{20}$ have referred to this re-evaluation as a retrospective pretest, and to the re-evaluation as a response-shift effect. The sample in which they investigated this phenomenon were undergraduates and not chronically ill patients. For this reason, the results of their study are difficult to generalize to the present context. Mancuso and Charlson ${ }^{21}$ have found similar results as in our study, using patients who had undergone total hip replacement, but the effect has been interpreted as recall bias. The study of Mancuso and Charlson ${ }^{31}$ determined if there were systematic biases to the disagreement between actual and recalled status. Their results showed that there were differences in the number of patients who had recollection error for the different domains. Furthermore, no trend of systematic bias was found, and finally, the magnitudes of the biases were not the same within a sub-group. This contradicts our findings in which parameter estimation showed a strong linear trend of systematic bias, and small standard deviation of the results within the study group. Adaptation as an explanation for the observed phenomenon matches the results found in the present study, in contrast to recall bias.

Recently, Guadagnoli and Cleary ${ }^{22}$ concluded that a change in health status did not vary by whether a baseline assessment was recalled, or was collected prior to the intervention. These results are difficult to reconcile with the present results. Note, however, that Guadagnoli and Cleary relied on patients with acute myocardial infarction. In contrast, the present study used chronically ill insulin dependent patients with end stage renal disease. Patients who have insulin dependent diabetes and end stage renal disease are disturbed with regard to their well-being, but as time goes by this impaired well-being leads to a decrease of the patients' internal standard against which the disease is evaluated.' In other words, 'time is a great healer'. On this basis, one cannot expect to find similar adaptation effects in acute patients as in chronically ill patients. The results found by Mancuso and Charlson ${ }^{21}$ underline this fact.

Finally, it should be remarked that this study suffered from some methodological limitations. The sample size was small, due to the highly specialized and relatively rarely performed intervention and because only few patients met the inclusion criteria for the procedure. Because of this small sample size, a conservative approach towards significance was used. Also it should be noted that patients' ability to recall prior functioning can vary by the type of scale employed. In this study only a VAS was used, which measured QoL. Meanwhile, these limitations do not invalidate the conclusion that can be drawn from the current results: Retrospective QoL measurements do not reflect patients' subjective state to which retrospective measurements are referring. 


\section{Acknowledgement}

We gratefully acknowledge the access to the patients in the following centres in alphabetic order:

Groningen AM Tegzess; University Hospital Groningen

Leiden FJ van der Woude; University Hospital Leiden

Leuven Y Vanrenterghem; University Hospital Gasthuisberg

Maastricht JP van Hooff; University Hospital Maastricht

Nijmegen RAP Koene; University Hospital Nijmegen

\section{References}

1 Editorial... Quality of life. Lancet 1995;346:1-2.

2 van den Bos GAM, Limburg LCM. Public health and chronic diseases. Eur J Public Health $1995 ; 5: 1-2$.

3 Adang EMM, Ament A, Dirksen CD. Medical technology assessment and the role of economic evaluation in health care. Journal of Evaluation in Clinical Practice 1996;2;4:287-294.

4 Gill TM, Feinstein AR. A critical appraisal of the quality of life mensurements. JAMA 1994;272:619-26.

5 Calman KC. Quality of life in cancer patients - an hypothesis. Journal of medical ethics $1984 ; 10: 124-27$.

6 Cassileth BR, Lusk EJ, Strouse TB, etal. Psychosocial status in chronic illness: a comparative analysis of six diagnostic groups. N Engl J Med 1984;311:506-11.

7 O'Boyle CA, McGee $H$, Hickey A, O'Malley $K_{\text {, Joyce }}$, RB. Individual quality of life in patients undergoing hip replacement. Lancet 1992;339:1088-91.

8 Heyink J. Adaptation and well-being. Psycholl Rep 1993;73:1331-134.

9 Najman J, Levine S. Evaluating the impact of medical care and technologies on the quality of life: a review and critique. Social Science \&x Medicine 1981;15F:107-115.

10 Taylor SE. Adjustment to threatening events. Am Psychol 1983;38:1161-1173.

11. Brickman P, Coates D, Janoff-Bulman R. Lottery winners and accident victims: Is happiness relative? J Pers \& Soc Psychol 1978;36:917-927.

12 Weinstein ND. Unrealistic optimism about future life events. J Pers \& Soc Psychol 1980;39:806820.

13 Tisevat J, Cook EF, Green ML. et.al. Health values of the seriously ill. Ann Intern Med $1995 ; 122: 514-520$.

14 Adang EMM, Engel GL, van Hooff JP, Kootstra G. Comparison prior to and after uransplantation of pancreas-kidney and pancreas-kidney with loss of pancreas. 'Transplantation $1996 ; 62 ; 6: 754-758$.

15 Froberg DG, Kane RL. Methodology for measuring health-state preferences-II: scaling methods. J Clin Epidemiol. 1989;5:459-471.

16 Bradburn NM. The structure of psychologicall well-being. Chicago: Aldine; 1969. 
17 CBS. Leefsituatie Nederland: Kerncijfers; 1983 : pp. 87.

18 Kiebert GM, van Oosterhout ECAA, van Bronswijk H, Lemkes HHPJ, Goosen HG. Quality of life after combined kidney-pancreas or kudney transplantatation in diabetic patients with endstage renal disease. Clin Transplantation 1994;8:239-45.

19 Herrmann D., Reporting current, past, and changed health status. What we know about distortion. Med Care 1995;33:AS89-AS94.

20 Howard GS, Dailey PR, Gulanick NA. The feasibility of informed pretests in attenuating response-shift bias. Applied Psychological Measurement 1979;Vol.3(4):481-494.

21 Mancuso CA, Charlson ME. Does recollection error threaten the validity of cross-sectional studies of effectiveness? Med Care 1995;33:AS77-AS88.

22 Guadagnoli E, Cleary PD. How consistent is patient-reported pre-admission health status when collected during and after hospital stay? Med Care 1995;33(1):106-112. 
7 Discussion, Conclusions, and

Recommendations 


\section{Medical Technology Assessment and Policymaking}

An inventory of the results of studies funded by the Developmental Medicine Committee of the Health Insurance Executive Board provides information about the methodological quality of these studies in the Netherlands. Up to 1995, seventeen studies were finished and reported to the Health Insurance Executive Board ${ }^{t}$, for evaluation by the Committee. Three criteria were used to check the quality (not only methodological) of the studies: 1) Was the study performed as a Randomized Controlled Trial (RCT)? 2) Was some kind of cost-effectiveness analysis (CEA) done (evaluation of costs and effects)? 3) Did the Health Insurance Executive Board make policy recommendations on the basis of the studies? Table 1 displays the results, which have been validated by the secretariat of the Health Insurance Executive Board.

Table 1 shows that although a rather limited number of studies were RCT's (5 out of 17) and only a moderate number provided cost-effectiveness data (10 out of 17), most studies (15 out of 17) provided enough information for the Health Insurance Executive Board to make unambiguous policy recommendations. The Friedman test statistic was applied to the null hypothesis that three related variables (RCT, CEA, Policy) came from the same population. According to this test, the null hypothesis could be rejected $(p<0.005)$, which means that there is no significant relation between RCT, CEA and Policy recommendations.

Buruma $^{b}$ states that the evaluation of the final reports of the Developmental Medicine Committee, funded by the Dutch Health Insurance Executive Board, resulted in a relatively low return in terms of concrete policy decisions during the last 10 years. According to Buruma, one of the reasons for this is the longstanding lack of clarity regarding the concept of 'Developmental Medicine'. According to Boer ${ }^{c}$ the 25 final reports of the Developmental Medicine Committee on which the Minister of Health made a decision can be classified as follows: 4 interventions which were denied access to the health care market, 17 cases which involved a decision about a benefit package, 6 cases on planning and 4 cases on reimbursement (some projects resulted in more than one decision). Both Buruma and Boer emphasized the importance of evidence-based research, meaning research of methodologically good quality. Finally, it should be remarked that recent studies

b

Bumuma, Chairman of the Board of Directors, University Hospital Leiden, at the conference on Toepassing van Medical Technology Assessment in de prakijk; Erasmus University Rotterdam, November 1996

$\mathrm{c}$

Boer, Health Insurance Executive Board, at the conference on Toepassing van Medical Technology Assessment in de praklijk; Erasmus University Rotterdam, November 1996 
funded by the Health Insurance Executive Board are subject to higher methodological standards and are obliged to include some kind of cost-effectiveness analysis. ${ }^{1}$

Some authors state that it should be recognized that the purpose of a RCT is mainly to assess the efficacy of a treatment rather than to demonstrate its efficiency (cost-effectiveness). ${ }^{2}$ Whereas cost-effectiveness analysis should be based on the 'real world', a RCT neglects most aspects of the 'real world'. ${ }^{2}$ According to Baltussen et. al. ${ }^{2}$, this problem can be overcome by adding sensitivity analyses with regard to the important 'cost drivers' to the RCT . For example, sensitivity analyses should be applied if it is suspected that the duration of RCT's tends to be too short to provide certainty about the full economic consequences of medical technologies. It is also said that RCT's conflict with the 'real world' regarding the age-structure of patients. ${ }^{2}$ In our opinion, this has little to do with the concept of the RCT, but more with the concept of sampling.

Table 1 Quality Evaluation "Developmental projects reported untill autumn 1995"

\begin{tabular}{|c|c|c|c|}
\hline Study (in Dutch) & $\mathrm{RCT}$ & CEA & $\begin{array}{c}\text { Policy } \\
\text { recommen- } \\
\text { dation }\end{array}$ \\
\hline $\begin{array}{l}\text { Functionele neurochirurgie bij focale } \\
\text { epilepsie }\end{array}$ & No & No. & Yes \\
\hline $\begin{array}{l}\text { Somatostatine scintigrafie in de endocriene } \\
\text { oncologie }\end{array}$ & No & No & Yes \\
\hline $\begin{array}{l}\text { In het schedelbeen verankerde } \\
\text { hoortoestellen }\end{array}$ & No & Yes & Yes \\
\hline Groepstherapie bij spondylitis & Yes & Yes & Yes \\
\hline Trombose diagnostiek & Yes & No & No \\
\hline $\begin{array}{l}\text { Diepe hyperthermie als toevoeging aan } \\
\text { radiotherapie }\end{array}$ & Yes & Yes & Yes \\
\hline Chirurgische behandeling maagkanker & Yes & No & No \\
\hline 131-I-MrBG bij neuroblastoom & No & No & Yes \\
\hline Biosynthetisch groeihormoon & No & Yes & Yes \\
\hline Allogene beenmerg transplantaties & No & No & Yes \\
\hline Licht therapie bij winterdepressie & Yes & No & Yes \\
\hline ECMO bij pasgeborenen & No & Yes & Yes \\
\hline Tandheelkundige implantaten & No & Yes & Yes \\
\hline
\end{tabular}




\begin{tabular}{l|ccc}
\hline Study (in Dutch) & RCT & CEA & $\begin{array}{c}\text { Policy } \\
\text { recommen- } \\
\text { dlation }\end{array}$ \\
\hline Elektrostimulatie lage urinewegen & No & Yes & Yes \\
Diagnostiek dementiesyndroom & No & Yes & Yes \\
Stereotactische bestraling & No & Yes & Yes \\
Dynamische gracilis plastiek & No & Yes & Yes \\
\hline
\end{tabular}

Source: Ziekenfondsraad, Adviezen Ortwikkelingsgeneeskunde, 1995 nummer 675.

The question is whether the trial population is representative of the target population. The concept of random assignment refers to groups being considered equivalent. Equivalence does not mean that every subject in one group is exactly equal to a subject in the other group. It does mean that any differences between the groups have been distributed as a function of chance alone. This means that systematic bias ${ }^{3}$ is excluded and this is the main purpose of RCT"s.

Mitchell $^{4}$ (Pharmaceutical Evaluation Section of the Commonwealth Department) emphasizes the importance of a hierarchy of primary evidence for economic evaluation, as follows: randomized head to head trials, transitive analysis of randomized head to head trials, observational studies, expert opinion. Furthermore, with regard to linking research and policymaking, Drummond ${ }^{5}$ mentions a number of ways to increase the relevance of economic appraisal results: maintaining methodological standards, producing economic evidence in a timely fashion, increasing the local validity of study results, increasing the decisionmakers' involvement in the study, improving the dissemination of study results, taking note of the availability of policy instruments, and recognizing the conflicts and incentives surrounding the study. According to Buruma, the amount of good quality MTA and Evidence Based Medicine (EBM) research is quite limited. His guess is that at the most $2 \%$ of all medical treatments are well founded empirically.

It could be concluded that sometimes a less sophisticated design is sufficient to come up with the required information. However, one should be careful to generalize this statement. Organisations like the Cochrane Collaboration include mostly (only?)

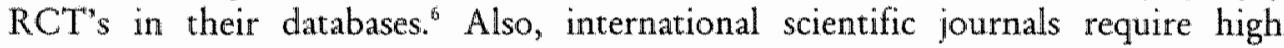
standards with regard to the study design used. This means that although a less sophisticated design can provide sufficient information, it is not likely to reach the target population (e.g., medical profession, policymakers). 


\section{Designs and Methodology}

Experiments are based on a logical structure, or design, in which the investigator systematically introduces changes into natural phenomena and then observes the consequences. The purpose of an experiment is to support a cause-and-effect relationship between a particular action or condition (the independent variable) and an observed response (the dependent variable). ${ }^{3}$ When extraneous variables are not controlled, they exert a confounding influence on the independent variable; that is, they contaminate the independent variable in such a way that the separate effects are obscured. ${ }^{3}$

In quantirative research there are basically two general scientific designs. One could be called 'true' experimental design, and the other 'quasi' experimental design. These designs can be described according to several types of design characteristics. The most basic distinction among them is the degree of experimental control. In a "true" experimental design, subjects are assigned at random to one of at least two comparison groups. A 'true" experimental design enables, theoretically, the exertion of control over most threats to internal validity, providing the strongest evidence for causal relationships. In this chapter we shall refer to these designs as 'randomized controlled trials' (RCT's). The gold standard in clinical research is the randomized "placebo" controlled double blind clinical trial", where neither the patients nor the investigators are aware of the identity of the treatment groups until after data are collected.

A 'quasi' experimental design does not meet the requirements of a 'true' experiment, as it lacks either randomization or comparison groups, or both. Examples of this kind of design are observational studies without controls or randomization, or both.

The use of a control group is often unfeasible in clinical situations, for practical or ethical reasons: This does not diminish the validity or usefulness of the study, but it does change the conclusions that can be drawn from the data. Another important aspect concerns the use of a "no treatment" or "placebo" group as a control in a study. A study which assesses whether a new treatment is more 'cost' effective than standard methods must include a "placebo" alternative, unless the standard treatment has been tested previously against an untreated control. When a placebo is not included and such a study results in improvement in both groups (new and alternative group untested against placebo), it would not be possible to determine whether both treatments were equally effective or whether both groups would have improved spontaneously without any intervention. It is reasonable to design studies with comparative treatments as controls when previous or simultaneous research 
clearly establishes their effectiveness against a true control group (e.g. no treatment; placebo).

Two studies, 'Dynamic Graciloplasty" (DGP) and 'combined Pancreas Kidney Transplant' (PKT) had methodological shortcomings. These shortcomings led to a decrease in the strength of the conclusions drawn from these studies. The design of the Dynamic Graciloplasty study could be questioned with regard to the "costeffectiveness' issue. The 'combined Pancreas Kidney Transplant' study suffers from the small size of the sample, and the lack of good controls. In this chapter these shortcomings will be discussed and put into a broad perspective.

\section{Dynamic Graciloplasty, a discussion of the methodology}

What was the reason for not designing the DGP study as a double blind placebo controlled RCT? A double blind was not possible in this study. The surgeon who performed the operations was the primary investigator. A sham operation was seen as unethical with regard to the patients. Clinicians find it morally distasteful to deny a patient treatment. ${ }^{3}$ In this study, patients were supposed to be their own controls. The discussion about whether a placebo controlled trial is ethical is an issue not only in surgical trials but also in medicine trials. According to Jones et al. ${ }^{7}$, for certain indications, with a number and range of medicines already available, it would be unethical to perform a placebo controlled trial. Some authors have questioned whether placebo controlled trials are used excessively and unethically. ${ }^{8 \cdot 10}$ Others ${ }^{11}$ have proposed that, once licensed, new drugs should be compared with existing treatments for the same indication in order to examine their relative costeffectiveness. For this purpose large randomised trials are the appropriate tool. ${ }^{11}$

The primary task of the DGP protocol was to demonstrate clinical effectiveness in patients with congenital or acquired faecal incontinence. Establishing costeffectiveness of the treatment was formulated as a secondary question in the protocol. 'To answer the primary question a RCT was unnecessary, because a 'one group pretest-posttest' design was sufficient. 'This design involves one set of measurements taken before and after treatment in one group of patients. The effect of treatment is determined by comparing pretest and posttest scores. This design is relatively weak because it has no comparison group, making it vulnerable to threats to internal validity. It is theoretically possible that some events other than the experimental treatment occurred within the time frame of the study and caused the observed change. However, this design can be defended when previous research has documented the behaviour of the control group in similar circumstances. This was the case here. ${ }^{12}$ Furthermore, control was increased by expanding the 'one group 
pretest-posttest" design to a 'repeated measures design" or a 'within subjects' design. This was done by adding one post-operative measurement (at 12 months) to the set of pre-postmeasurements.

The second question, 'to decide whether DGP is a cost-effective treatment', was answered in a similar way. The guidelines for a cost-effectiveness' analysis ${ }^{13}$ demand a perspective from which the study is considered. The proper perspective for this kind of analysis is the societal perspective. ${ }^{13}$ Our study wras funded by the Health Insurance Executive Board in the Netherlands, which advises the Minister of Health. Their perspective is identical to the societal perspective, from which the study was performed.

The next issue is a comprehensive description of the competing alternatives. From the set of competing alternatives the most "common" one should be compared to DGP. In the 'one group pretest-posttest design' only one alternative is recognized. This is 'doing nothing or as stated in Chapter 3 and 4 'conventional treatment'. Based on expert opinion and on the literature ${ }^{12}$ one important alternative was not included in the protocol. This was the treatment of creating a colostomy. It is difficult to judge whether the patients in the study group considered a colostomy as an alternative for their incontinence. DGP was the only way to restore anal continence versus a manageable form of incontinence on the abdominal side. As this alternative was not taken into consideration at the beginning of the study it was impossible to incorporate it later on in the prospective design of the study. Later on, during the study, seven colostomy patients were evaluated for their treatment costs and expenditures related to stoma-care. A study of the literature was used for an impression of quality of life of ostomates (versus non-ostomates).

The question of whether DGP is cost-effective from a societal point of view could not be answered entirely. This is because the design was built on the primary question of clinical effectiveness. When dealing with "Medical Technology Assessments', clinical effectiveness and cost-effectiveness should be incorporated into one question addressing both. The design of choice should be the one which answers both issues to the full satisfaction of the sponsors of the study. Our study fully answers only the question about effectiveness.

Another longstanding problem in cost-effectiveness analyses is the measurement of costs. The most direct way to obtain cost estimates is by observing the physical process. This method (engineering method ${ }^{14}$ ) expresses standards in physical units for example, hours of labor, pounds of different input materials, minutes of operation time, days of hospitalization etc. These measurements can be transformed into costs by multiplying by the appropriate prices. Our analysis was done partly using the engineering method (number of operations, number of hospital days, 
number of outpatient visits) and partly in a determinist manner, using standards from the protocol (see Chapter 4). In the clinical and in the quality of life parts of the study the measurement of the variables was stochastic (the items have an observed mean and variance). A stochastic approach towards cost measurement (a full engineering method) could have been a simple solution for integrating clinical and quallity of life data with cost data. In that way both costs and effects could be expressed in terms of mean and standard deviation. The problem, however, has other aspects which have not been addressed. Drummond and $\mathrm{O}^{\prime} B \mathrm{Brien}^{15}$ note that analysis is complicated because the cost estimate in the cost-effectiveness ratio is the product of two factors measured in mostly different ways; The resource quantities (q) measured stochastically and the unit costs or prices of those items (p) mostly measured deterministically.

A possible solution could be to measure only volumes of independent performances (e.g. hospital days, personnel FTE's, materials, lab tests, drugs etcetera). If we can obtain such estimates of the pattern of variation for physical measures of the inpurs to the health(production) process, then the current production cost function can be obtained by pricing each major component by its current average unit price. However, it should be remarked that it is often very difficult to relate certain inputs to the production process, for example, overhead costs (e.g., hospital management, hospital insurance policies, clinicians secretaries etc.). For example, how should the hospital management (input) be allocated to DGP (output). When there is no direct relation to the production process it is an almost impossible task to express these indirect inputs in stochastic terms. Another perspective could be a marginal cost approach. The term 'marginal cost" refers to the cost of providing one more unit of service, which is mostly equal to the variable cost per unit (performance). An advantage of this approach is that overhead and centre specific costs are excluded (e.g., depreciation of the building) from the analysis, which improves comparison in general. When a full cost price is requested in addition to an incremental or marginal "cost effectiveness" ratio, a determinist approach is best. In most cases it is difficult, if not impossible, to determine fixed costs and overhead stochastically (by the engineering method). The determinist approach is the most consistent for this information. 


\section{Conclusions of the Dynamic Graciloplasty Study}

- DGP is a clinically effective treatment to cure faecal incontinence (Chapter 3).

- The question whether DGP is the most efficient treatment to cure faecal incontinence cannot be answered from a societal perspective.

- On the basis of full costing, DGP is more expensive than conventional treatment, but less expensive than a colostomy (Chapter 4).

- Quality of life (QoL) of successful DGP is better than for conventional treatment. Moreover, unsuccessful DGP does not lead to deterioration in QoL (Chapters 3 and 4).

- Patients with longstanding incontinence are better adapted to their imperfect health status than patients who have been incontinent for a shorter time (Chapter 3).

\section{A methodological discussion of combined Pancreas Kidney Transplants}

In the Netherlands the 'combined Pancreas Kidney Transplant" (PKT) is a highly specialized procedure which involves many risks for the patient. For that reason the inclusion criteria were restrictive. This resulted in a rather small target population. The problem of the small sample size was recognized at the beginning of the study. Performing the research as a multicenter study was a way of dealing with this problem. Unfortunately this could not solve the problem, as the sample size remained relatively small. Enlarging the sample size by taking more foreign centres into the study was considered, but rejected on the grounds that this would make it more complicated (measuring 'quality of life' in different languages and perhaps even different cultures) and far more costly (there was a limited budget for this research program). The risk of accepting relatively small sample size is that it could imply that a detected difference may not have any clinical relevance." Several earlier studies have shown considerable differences between Dialysis and PK.T. ${ }^{16}$ These findings made it likely that enough power could be reached even with a rather limited sample size to find significant differences between PKT and Dialysis.

Another problem with the PKT study was the control group. Should patients be their own controls, comparing PK'T with Dialysis, or should PKT be compared with a more common alternative, a single kidney transplant ( $K$ Tx)? "There was general agreement that Dialysis could not be the only alternative being evaluated, although it was necessary to incorporate this alternative to establish effectiveness. There were ethical as well as practical objections to allocating patients from the target population to a K Tx group and a PKT group. From a methodological point 
of view the best design would have been a 'pretest-posttest control group design' in which both groups are tested prior to (on dialysis) and following treatment. The patients from the target population should be assigned randomly to one of the groups, KTx and PKT. This design relates much more closely to the real world where patients choose between a PKT or a KTx. According to Spilker ${ }^{17}$, the real world is "...the manner in which a particular medicine or treatment is usually used, given, or administered'.

On ethical grounds, one could question the decision to assign patients at random to a KTx or PKT procedure. In situations where the effectiveness of a treatment is being questioned because current knowledge is inadequate (which was the case with PKT, especially concerning the long term), it may actually be more ethical to take the time to make appropriate controlled comparisons than to continue clinical practice using potentially ineffective techniques. ${ }^{3}$ If, during the trial, results indicate that one treatment is much more beneficial, the randomization procedure could be abandoned. Although in our study randomization was not an option, a control group other than dialysis was still needed. A new and original solution to the problem was designed. A control group was constructed from patients who initially had a PKT but in whom the pancreas was rejected or thrombosed soon after the transplant procedure. This methodology suffers from several methodological shortcomings. ${ }^{16}$

The problem of the small sample size persisted, and it was impossible to determine the effectiveness of treatment within the time frame of the study. The dilemma in this, ethics aside, was the choice between a methodologically excellent design which lacked the power to determine any relevant changes in effect between groups (PKT and $\mathrm{KTx}$ ) and within groups (Dialysis versus PKT and KTx), and an imperfect design which probably had enough power to detect a relevant effect within one group (Dialysis versus PKT), but lacked the power to determine relevant changes between groups (PKT and KTx or in this case PKT.P).

Another methodological aspect regarding the measurement of 'quality of life' concerns the fact that chronically ill patients, who successfully underwent a combined pancreas-kidney transplant, significantly lower their perception of the experienced baseline global QoL in retrospect. ${ }^{1 *}$ This baseline QoL state changed due to improved health status following the transplant procedure (see Chapter 6). The patients' "reality mix" was subsequently changed and they looked at their pretransplant QoL from a different perspective, which did not reflect the perspective at baseline. The effect of patients adapting to their 'imperfect' health state could not be measured retrospectively. This leads to the conclusion that retrospective QoL assessment differs from prospective QoL assessment. ${ }^{18}$ 


\section{Conclusions of the combined pancreas kidney study}

- Successful PKT restores both nephropathy and diabetes and increases QoL compared to dialysis (CAPD and HEMO) (Chapter 5).

- PKT-P restores nephropathy and increases QOL compared to dialysis (CAPD and HEMO) (Chapter 5).

- Due to small sample size no significant evidence about QoL differences between PKT and PKT-P could be found. A strong tendency in favour of the PKT group was found with regard to QoL (Chapter 5).

- Although there is an evident need for long-term data on patient survival, graft survival, diabetic complications and QoL, conclusions can be drawn only for the short term, e.g. 18 months after the transplant procedure (Chapter 5).

- A RCT with sufficient power and duration is necessary to determine whether PKT is better than KTx with regard to QoL, graft survival and other important effects.

- Retrospective QoL measurement differs significantly from prospective QoL measurement in chronically ill patients (Chapter 6).

- A likely explanation for the difference between prospective versus retrospective measurement is the adaptation effect in chronically ill parients (Chapter 6).

\section{DGP and PKT studies, were they worthwhile?}

The DGP study resulted in a positive recommendation of the Health Insurance Executive Board to the Minister of Health. At this point, it is very likely that DGP will be added to the benefit package. The University Hospital Maastricht is allowed to treat 50 patients yearly with this new procedure. Scientifically the study was worthwhile because many other centres, across the world, began to use the DGP procedure on the basis of our scientific publications, and tried to get the treatment reimbursed in their own countries. Furthermore, the DGP procedure was applied to different patient groups. ${ }^{19}$

There is still a great deal of discussion about combined PK'T. The clinical results were disappointing. ${ }^{16}$ The value of the study is that it shows the state of the art with regard to combined PKT in the Netherlands and Belgium. The need for more research is evident, especially research on the long-term evaluation of quality of life, graft survival and patient survival. It should also be noted that a critical approach towards combined PKT opens the discussion on other modalities to restore insulin function, such as the Islet transplant procedure. 


\section{Recommendations concerning MTA studies in the clinical practice}

- MTA studies need a multidisciplinairy approach right from the beginning of constructing the research protocol.

- Whereas the purpose of such studies is primarily establishing efficacy/effectiveness and efficiency (cost-effectiveness), both aspects (clinical effectiveness and cost-effectiveness) should be incorporated in the primary research question, as well as the alternatives identified by establishing effectiveness and efficiency.

- The study design should be the best controlled design possible, according the criteria of ethics, statistics, and infrastructure. One could question whether budgetary aspects are also legitimate criteria in deciding not to perform a well controlled study.

- In cost-effectiveness analysis, all possible alternatives should be identified. The treatment under evaluation should be compared with the alternative, which is broadly understood as the common practice treatment. Furthermore, from a methodological point of view, a doing nothing or placebo alternative should be incorporated with regard to effectiveness, unless the common practice treatment has been tested previously against an untreated control.

- 'The study should incorporate scenario and sensitivity analyses to deal with uncertainty which can't be explained in the design.

- Studies assessing QoL in chronically ill patients in a retrospective fashion lead to different and probably misleading conclusions in comparison with studies relying on actual QoL. Further theoretical as well as experimental research into this issue is needed. 


\section{References}

1 Ziekenfondsraad, Adviezen Ontwikkelingsgeneeskunde, 1995 nummer 675.

2 Baltussen $R_{x}$ Ament $A$, Leidl $R$. Making cost assessments based on $R C T$ s more useful to decision makers. Health Policy; 1996;37:163-183.

3 Portney LG, Watkins MP. Foundations of clinical research: applications to practice. Appleton \& Lange, Norwalk, Connecticut, 1993.

4 Mitchell A. Pharmaceutical guidelines: current position and possible changes, In: C. Selby Snith and MF Drummond (Eds.). Economic Evaluation in Australian Healch Care. Conmonwealth of Australia. Canberra 1995.

5 Drummond MF. Evaluation of health technology: economic issues for health policy and policy issues for economic appraisal, Social Science and Medicine 1994;38:1593-1600.

6 Kleijnen J, De Vet HCW, Rinkel GJE, Keirse MJNC. De Cochrane Collaboration; systematische overzichten van kenmis uit gerandomiseerd onderzoek. Ned Tijdschr Geneeskd $1995 ; 22 ; 139: 1478-1482$.

7 Jones B, Jarvis P, Lewis JA, Ebbutt AF. Trials to assess equivalence: the importance of rigorous methods. BMJ 1996;313:36-39.

8 Rothman KJ, Michels KB. The continuing unethical use of placebo controls. N Engl J Med 1994;331:394-398.

9 Taubes $G$. Use of placebo controls in clinical trials disputed. Science 1995;267:25-26.

10 The use of placebo controls. N Engl J Med 1995;332:60-62.

11 Henry D, Hill S. Comparing treatments: comparison should be against active treatments rather than placebo. BMJ 1995;310:1279.

12 Baeten CGMI, Geerdes BP, Adang EMM, et al. Anal Dynamic Graciloplasty in the treatment of intractable fecal incontinence. N Engl J Med. 1995;332:1600-1605.

13 Drummond M.F., Ludbrook A., Lowson K. and Steele A. Studies in Economic Appraisal in Health Care, Vol. 2. Oxford University Press, Oxford, 1987.

14 Kaplan RS., Advanced management accounting, Prentice Hall International, Lnc. London, 1989.

15 Drummond MF, $\mathrm{O}^{\prime}$ Brien B. Clinical importance, statistical significance and the assessment of conomic and quality of life outcomes. Health Economics 1993; 2:205-212.

16 Adang EMMM, Kootstra G, Engel GL et. al. Comparison prior to and after transplantation of pancreas-kidney and pancreas-kidney with loss of pancreas, a prospective controlled Quality of Life study. Transplantation 1996; 62;6:754-758.

17 Spilker B. Guide to Clinical Trials. Raven Press, New York, 1991.

18 Adang EMM, Kootstra G, Engel GL, Baeten CGMI. Quality of life ratings in patients with chronic illnesses. JAMA 1997;277;13:1038.

19 Geerdes BP, Heineman E, Zoetmulder FAN, Adang EMM, Vos E, Soeters PB, Baeten CGMI. De dubbele Dynamische gracilis plastiek: alternatief voor het colostoma na een volledig verlies van het anorectum? Ned Tijdschr Geneeskd 19966 april;140(14)pp:773-776. 


\section{ummary}

The aim of this thesis is to present two experimental studies, Dynamic Graciloplasty and the Combined Pancreas Kidney Transplant. Procedure, both performed in the Netherlands. These studies incorporated aspects of Medical Technology Assessment (MTA). Furthermore, the phenomenon that prospective quality of life judgements differ from retrospective quality of life judgements is an important issue in this thesis. The final aim of this thesis is to formulate recommendations for further improvement with regard to the quality of MTA.

In Chapter 1 the concept of MTA and the role of economic evaluation in MTA is described. Furthermore, an explanation of the techniques for economic evaluation: cost-benefit, cost-effectiveness, and cost-utility analysis is given. It is shown how these techniques are applicable in practice. An evaluation of these techniques, in the context of wellfare economic theory, is presented as well. The most important conclusions drawn from Chapter 1 are that economic evaluation in MTA research is increasingly important, and that economic evaluation gives important additional information to policymakers. Finally, MTA covers a wide spectrum of evaluations and considerations and therefore reaches far beyond the calculation of 'costs per quality adjusted life year or 'cost per effect' only.

Chapter 2 addresses one of the characteristic features of MTA, the multidisciplinairy approach. This chapter illustrates the multidisciplinairy cooperation between a surgeon and an economist, using practical examples which led to a winwin situation.

The next chapter reports on an empirical study which investigated the quality of life of patients who underwent Dynamic Graciloplasty in the treatment of intractable fecal incontinence. This study showed that Dynamic Graciloplasty improved the quality of life in a number of significant domains, if continence could be achieved. Failure of the technique did not affect quality of life significantly.

Chapter 4 reports on an empirical study on the costs of the procedure Dynamic Graciloplasty compared to the common alternative treatments, in the Dutch health care setting. The cost analysis was done from a societal perspective. Furthermore, quality of life data from Chapter 3 were extended to 43 patients, and combined with the cost data, resulting in a cost-effectiveness analysis. The cost analysis showed that the colostomy alternative was the least attractive, given the indication. The colostomy alternative costs US $\$ 43,000$, more than Dynamic Graciloplasty, without 
any indication that a colostomy leads to a better quality of life than Dynamic Graciloplasty. The costs of Dynamic Graciloplasty (US $\$ 31,700$ ) were higher than for conventional therapy (US $\$ 18,500$ ), whereas quality of life after Dynamic Graciloplasty was better on several domains.

Chapter 5 reports on an empirical multicenter study which investigated quality of life of insulin dependent patients with end stage renal disease, who underwent a Combined Pancreas Kidney Transplant. A successful Combined Pancreas Kidney Transplant restores both nephropathy and diabetes and increases the quality of life compared to dialysis (CAPD and HEMO). Even when the pancreas is rejected or thrombosed after the transplant procedure, nephropathy is restored and increased quality of life is found.

Chapter 6 reports on an empirical study which investigated the phenomenon of whether prospective quality of life judgements differ from retrospective quality of life judgements. This study provided information about the difference between quality of life ratings pertaining to the current situation and those pertaining to a previous time period. An explanation for this phenomenon is the patients" adaptation to health status. The use of cross-sectional designs in the quality of life measurement, in which patients are asked to re-evaluate their pre-treatment quality of life, leads to exclusion of the adaptation effect and therefore under-estimation of the pre-treatment quality of life. The hypothesis above was tested, and on that basis it could be concluded that retrospective quality of life judgements significantly differ from prospective quality of life judgements.

Finally, Chapter 7 presents a discussion about the methodological issues concerning the empirical studies in this thesis. Explicit conclusions are formulated, and finally, recommendations are made with regard to future MTA's. 


\section{amenvatting}

In dit proefschrift worden twee experimentele studies, de Dynamische Gracilis Plastiek en de gecombineerde Pancreas-Nier transplantatie, beschreven. In beide studies worden aspekten van 'Medical Technology Assessment' (MTA) belicht. Daarnaast is er een belangrijke plaats voor de hypothese: prospectieve kwaliteit van leven meting leidt tot andere uitkomsten dan retrospectieve $k$ waliteit van leven meting. Tenslotte beoogt dit proefschrift aanbevelingen te formuleren voor verdere verbeteringen van MTA onderzoek.

In hoofdstuk 1 wordt het concept MTA en de rol van de economische evaluatie hierin beschreven. Tevens worden de technieken voor economische evaluatie besproken: de kosten-baten-, kosten-effektiviteits-, en de kosten-utiliteitsanalyse. Tenslotte worden deze technieken geëvalueerd tegen de achtergrond van de economische theorie van de verdeling van middelen, en wordt beschreven in hoeverre deze technieken in de praktijk toepasbaar zijn. De belangrijkste conclusies van dit hoofdstuk zijn achtereenvolgens: de toenemende rol van economische evaluatie in MTA studies en de onderkenning dat economische evaluatie waardevolle toegevoegde informatie biedt aan beleidsmakers. Tevens wordt geconstateerd dat MTA meer is dan uitsluitend economische evaluatie en overwegingen. MTA is in feite een heel spectrum van evaluaties en overwegingen vanuit verscheidene disciplines.

Hoofdstuk 2 stelt een van de typische eigenschappen van MTA onderzoek aan de orde: de multidisciplinaire benadering. Deze multidisciplinaire benadering wordt geillustreerd aan de hand van de "econoom" en de "chirurg", waarbij voorbeelden uit de praktijk blijken te leiden tot een win-win situatie.

Hoofdstuk 3 beschrijft een empirische studie waarbij de kwaliteit van leven wordt onderzocht bij patienten met fecale incontinentie die een nieuwe behandeling, de Dynamische Gracilis Plastiek, ondergaan. Uit deze studie blijkt dat, wanneer de behandeling resulteert in continentie, kwaliteit van leven toeneemt op een aantal significante domeinen. Het mislukken van de behandeling heeft geen negatieve invloed op de kwaliteit van leven bij deze patienten.

Hoofdstuk 4 presenteert een empirische studie naar de kosten van de nieuwe behandeling, de Dynamische Gracilis Plastiek, waarbij deze vergeleken wordt met de meest gebruikelijke alternatieven in Nederland. Daarnaast worden de kwaliteit van leven data uit hoofdstuk 3 uitgebreid met 13 patienten. Het combineren van 
kosten en kwaliteit van leven resulteert in een kosten-effektiviteitsanalyse. De kosten analyse laat zien dat het stoma alternatief de duurste oplossing voor fecale incontinentie is. Deze behandeling kost zo'nUS $\$ 43000$ meer dan de Dynamische Gracilis Plastiek, terwijl er geen indicatie is dat de stoma behandeling tot een betere kwaliteit van leven leidt dan de Dynamische Gracilis Plastiek. De kosten van deze latste, zo'n US $\$ 31700$, zijn hoger dan voor de conventionele behandeling (het tweede alternatief: niets doen), zo"n US $\$ 18500$, terwijl $k$ waliteit van leven na een Dyramische Gracilis Plastiek op een aantal belangrijke domeinen beter is.

Hoofdstuk 5 bespreekt een empirische multicenter studie die de kwaliteit van leven onderzoekt bij patiënten, met insuline afhankelijke diabetes en terminaal nierfalen (dialyse), die een gecombineerde pancreas-nier transplantatie ondergaan. Een succesvolle transplantatie herstelt de nierfunctie en de insuline aanmaak. Dit leidt bij deze patiënten tot een $\mathrm{kwaliteit}$ van leven winst na transplantatie. Zelfs al vindt afstoting van het pancreas transplantaat plats, dan nog neemt de kwaliteit van leven in deze groep patiënten toe.

Hieropvolgend wordt in hoofdstuk 6 onderzocht in hoeverre prospectieve kwaliteit van leven beoordeling van retrospectieve kwaliteit van leven beoordeling verschilt. Deze studie geeft informatie over het verschil in kwaliteit van leven uitkomsten behorende bij de huidige situatie en die behorende bij een vorige tijdsperiode. Hieruit blijkt dat retrospectieve kwaliteit van leven meting significant verschilt van prospectieve kwaliteit van leven meting. De verklaring voor dit fenomeen is dat patiënten zich aanpassen aan hun imperfekte gezondheidstoestand. In de psychologie wordt dit fenomeen adaptatie genoemd. Indien men patiënten interviewt over hun kwaliteit van leven op dit moment dan zal hun beoordeling beinvloed worden door de mate waarin ze geadapteerd zijn aan hun gezondheidstoestand. Past men een cross-sectioneel design toe, waarbij de patiënten gevraagd worden hun gezondheidstoestand vóór de ingreep te evalueren, dan zal het adaptatie effect bij deze evaluatie uitgesloten worden. Bovenstaande wordt in hoofdstuk 6 empirisch getoetst.

Tenslotte wordt in hoofdstuk 7 een methodologische discussie gepresenteerd met betrekking tot de empirische studies in dit proefschrift. Conclusies worden in dit hoofdstuk nog eens naar voren gehaald. Uiteindelijk worden aanbevelingen gedaan voor de opzet van toekomstige MTA studies. 


\section{Dankwoord}

Allereerst wil ik mijn promotor Professor Dr. G. Kootstra bedanken. Uw streven om van iedere onderzoeker een promovendus te maken heeft absoluut bijgedragen aan het voltooien van deze dissertatie. Hierbij speelde "disciplinaire afkomst" geen rol. Ook uw pragmatische manier van omgaan met relatief complexe zaken en de vrijheid die u mij gunde bij het doen van onderzoek heb ik zeer gewaardeerd.

Cor Baeten, van jouw succes mocht ik mee genieten. Dit genieten was niet alleen wetenschappelijk, maar zeker ook het genieten van alle feestelijkheid waarmee jij regelmatig werd omgeven. Ik noem bijvoorbeeld de etentjes na iedere dynamische gracilis plastiek training, of de feestavonden ter gelegenheid van de zoveelste gracilis plastiek en niet te vergeten de festiviteit rondom onze New England publikatie. Ook de barbecue's bij jouw thuis wil ik hier niet vergeten, waarbij jouw vrouw, Karin, een prominente rol vervulde.

Gerard Engel, mijn dank voor de voortreffelijke wijze waarmee je mij wetenschappelijk op het juiste "promotie" spoor hebt gezet. Met name in mijn begin periode bij Chirurgie was je mijn meest intensieve begeleider. Graag denk ik terug aan ons bezoek aan een "Chirurgischen Arbeitstagung" in Berlijn/Potsdam in 1993. Ook Baltimore 1994 was een hoogtepunt, al was het maar omdat we daar de "outstanding poster award" in de wacht sleepten.

Dank gaat ook uit naar de stafleden van Chirurgie. Er zijn er maar weinig waarmee ik niet heb samengewerkt.

Bas. Geerdes en Joop Konsten ben ik dank verschuldigd. Hun perfekte klinische research samen met mijn socio-economische research was groter dan de som der delen.

Een woord van dank gaat ook uit naar mijn collega's op de research kamer wan Chirurgie door de jaren heen. Enigszins chronologisch waren dat: Dirk, Harry, Leo, Henk, Carmen, Bernadette en Steven. Met name Henk Pietersen "Bloody Henk" en Carmen Dirksen waren bronnen van inspiratie.

Mijn dank gaat ook uit naar Jean Vrancken, met name voor zijn creatieve ondersteuning bij bijna verlopen contracten.

Verder wil ik de collega"s van mijn huidige vakgroep "Beleid, Economie en Organisatie van Zorg", in het bijzonder de sectie Economie: Aggie, André, AnnePeter, Bert, Frits, en Rob bedanken voor hun collegiale steun en de mogelijkheden die mij geboden werden om mijn dissertatie af te ronden. In het bijzonder wil ik Jan van Emmerik bedanken, die mij heeft bijgestaan bij de finale opmaak van dit proefschrift.

Mijn ouders wil ik bedanken voor hun steun en belangstelling. 
Tenslotte wil ik mijn vrouw Balla en mijn dochter Anne-Kai bedanken, wiens liefde en zorg de setting creëerden die mijn promotie mogelijk heeft gemaakt. 


\section{T ist of Publications}

1. Quality of life after dynamic graciloplasty for faecal incontinence: first results. Adang EMM, Engel GL, Konsten J, Baeten CGMI. Theor. Surg 1993; 8: 122 124.

2. Surgeon and economist together in a study: a win-win situation! Ökonomie und Chirurgie: Konsens oder Dissens? Effektivität und Ökonomie Chirurgischen Handelns. Engel GL, Adang EMM, Kootstra G. in: E. Neugebauer und H. Troidl, Georg Thieme Verlag Stuttgart-New York 1994 pp.16-21.

3. Eindrapportage ontwikkelingsgeneeskunde project 91/066: De Dynamische Gracilis Plastiek, een nieuwe therapie voor faecale incontinentie, Deelrapport 'Kwaliteit van leven'. Adang EMM, Baeten CGMI, Geerdes B, Engel GL., Ziekenfondsraad, september 1994. (rapport)

4. Eindrapportage ontwikkelingsgeneeskunde project 91/066: De Dynamische Gracilis Plastiek, een nieuwe therapie voor faecalle incontinentie, Deelrapport 'Kosten analyse'. Adang EMM, Baeten CGMI, Geerdes B, Engel GL, Ziekenfondsraad, september 1994. (rapport)

5. Anal dynamic graciloplasty in the treatment of intractablle fecal incontinence. Baeten CGMI, Geerdes BP, Adang EMM, Heineman E, Konsten J, Engel GL, Kester ADM, Spaans F, Soeters PB. New Engl J Med 1995;332:1600-1605.

6. Medical technology assessment: economic evaluation of new technologies. Adang EMM, Dirksen CD, Engel GL, Baeten CGMI. British Journal of Hospital Medicine 1995;53:563-566.

7. Assessment of long-term Quality of Life 14 years after weight reducing surgery for Morbid Obesity. Gemert WG van, Adang EMM, Greve JW, Soeters PB. (Submitted)

8. Spinal cord stimulation and reflex sympathetic dystrophy. Spincemaille GH, Barendse G, Rouwet EV, Kurvers HAJM, Adang EMM, Kleef van M, Dingemans W, Wildenberg van de FAJM. The Pain Clinic 1995;8:155-160. 
9. Spinal cord stimulation in de behandeling van reflex sympathische dystrofie. Rouwet EV, Spincemaille GH, Barendse GH, Kleef van M, Adang EMM, Kurvers HAJM, Daemen MARC, Wildenberg van den FAJM. Nederlands tijdschrift woor pijn en pijnbestrijding 1996;16(1):8-11.

10. De dubbele Dynamische gracilis plastiek: alternatief voor het colostoma na een volledig verlies van het anorectum? Geerdes BP, Heineman E, Zoetmulder FAN, Adang EMM, Vos E, Soeters PB, Baeten CGMI. Ned Tijdschr Geneeskd $1996 ; 140 ; 14: 773-776$.

11. Cost-effectiveness of the dynamic graciloplasty as a therapy for fecal incontinence. Adang EMM, Engel GL, Rutten FFH, Geerdes B, Baeten CGMI. (In press Dis Colon Rectum)

12. Comparison prior to and after transplantation of pancreas-kidney and pancreas-kidney with loss of pancreas, a prospective controlled Quality of Life study. Adang EMM, Engel GL, van Hooff JP, Kootstra G. Transplantation $1996 ; 62,6,754-758$.

13. Quality of life Ratings in patients with chronic illnesses. Adang EMM, Kootstra G, Engel GL, Baeten CGMI. JAMA 1997;277;13:1038.

14. Do type I diabetic patients with end-stage renal disease adapt to their illness? A study in Pancreas Kidney Transplant patients. Adang EMM, Kootstra G, Engel GL, Hooff van JP, Merckelbach HLGJ. (Submitted)

15. Cost-effectiveness of open versus laparoscopic repair for primairy inguinal hernia: A short and long term perspective. Dirksen CD, Ament AJHA, Adang EMM, Beets GL, Go PMNYH, Baeten CGMI, Kootstra G. (Submitted)

16. Medical technology assessment and the role of economic evaluation in health care. Adang EMM, Ament A, Dirksen CD. Journal of Evaluation in Clinical Practice 1996;2;4:287-294.

17. Technologie afgewogen. Adang EMM, Dirksen CD. Maandelijkse Column in Medisch Nieuws, Januari 1996-December 1996. 


\section{Curriculum Vitae}

Eddy Adang was born on May 9 th 1964 in Roermond, The Netherlands. In 1982 he graduated from the Bisschoppelijk College in Roermond. From 1982 till 1984 he attented the Technical University Twente. From 1984 till 1985 he fulfilled his military service in the Royal Dutch Army. In September 1985 he started studying Economics at the University of Maastricht, and graduated in December 1990. He worked one year as a Lecturer at the Faculty of Economics of Maastricht University. In Januari 1992 he started as a researcher at the Department of Surgery at the University Hospital Maastricht (Chairman Prof Dr G Kootstra). In April 1996 he became assistant professor at the Department of Health Organization, Policy and Economics at Maastricht University. 
Financial support for the publication of this thesis was generously provided by Medtronic - Interstim. 